\title{
HRAD U BOŽANOVA NA BROUMOVSKU A JEHO MOŽNÁ ÚLOHA PŘI STABILIZACI BROUMOVSKÉHO KLÁŠTERNÍHO DOMINIA
}

\author{
PAVEL DRNOVSKÝ - JANA MAZÁČKOVÁ - JOSEF ŠRÁMEK
}

\begin{abstract}
Abstrakt: Opevněné sídlo u obce Božanov neznámého jména, pro které nedisponujeme písemnými prameny, je možné dát do spojitosti s kolonizačním úsilím benediktinského kláštera v Broumově během druhé poloviny 13. století. Hrad sloužil jako opěrný bod vymezujíci klášterni majetky v nedávno osídleném prostoru broumovské kotliny vůči sousednímu Kladsku. Svědči o tom nejen lokace založení, ale i charakter samotné lokality. Nálezový inventár̆, který je složen zejména z kovových artefaktů, umožňuje chronologické určení do prủběhu druhé poloviny 13. století až počátku 14. století. Jeho skladba pak odkazuje na vojenskou úlohu lokality a přitomnost posádky. Násilný zánik hradu lze patrnè spojit s povstáním broumovských fojtů proti benediktinské vrchnosti. Neobnoveni lokality pak souvisi s již dokončenou konsolidací klášterni oikumeny a přebudováním opevněného sidla v samotném městě Broumově.
\end{abstract}

Klíčová slova: Broumov - hrad-kovové nálezy-militaria-kolonizace-13. století.

The castle near Božanov, in the Broumov region and its possible role in the stabilization of the Broumov monastery dominion

Abstract: The fortified seat (name unknown) near the village of Božanov for which there are no written sources can be linked to the colonization efforts of the Benedictine monastery in Broumov in the second half of the 13th century. The castle served as a foothold demarcating the monastery's property in the recently settled area of the Broumov basin in relation to neighbouring Glatz. This is evidenced by the location as well as by the character of the site. The repertoire of finds which chiefly comprise metal artefacts enables to date the castle to the second half of the 13th century - early 14th century. Its structure reflects the military role of the site and the presence of a garrison. The violent decline of the castle was probably associated with the uprising of Broumov magistrates against the Benedictine authority. The fact that the site was not restored points towards the completed consolidation of the monastery holdings and the reconstruction of a castle in the town of Broumov.

Key words: Broumov - castle - metal finds - militaria - colonization - 13th century.

\section{Úvod}

Společně se sídelními procesy kulminujícími v českých zemích v průběhu 13. a 14. století docházelo k postupnému uzavírání větších pozemkových majetků. Z písemných pramenů jsme bohatě informováni zejména o průběhu a formě řešení sporů mezi vlastníky v př́ípadech, kdy došlo k rozepři při vymezování hranic územních celků. Oproti tomu postrádáme jakékoliv písemné zmínky o řadě fortifikovaných lokalit, $\mathrm{v}$ jejichž budování spatřuje část badatelů snahu majitelů o zajištění a správu vznikajících dominií. Studie se věnuje opevněné lokalitě, jež byla založena nad vsí Božanov v Broumovském výběžku a kterou lze spojit s možným úsilím broumovských benediktinů o vymezení svého klášterství během osídlování Broumovské kotliny.

\section{Poloha a popis lokality}

Opevněná lokalita, jejíž původní jméno se v písemných pramenech nedochovalo, se nachází nedaleko vesnice Božanov v Broumovském výběžku (okr. Náchod; obr. 1). Podle názvu této vsi se pak fortifikace v současné literatuře označuje jako hrad u Božanova. Ačkoliv se o sídle $\mathrm{z}$ dob jeho provozu v průběhu vrcholného středověku písemnosti nedochovaly, tak v Hesseliově Broumovském urbáři ze 70. let 17. století je uvedeno, že na tomto místě přebývali lapkové. $\mathrm{Z}$ této tradice pochází i název Raubschloss, pod kterým lze lokalitu rovněž nalézt v regionální 


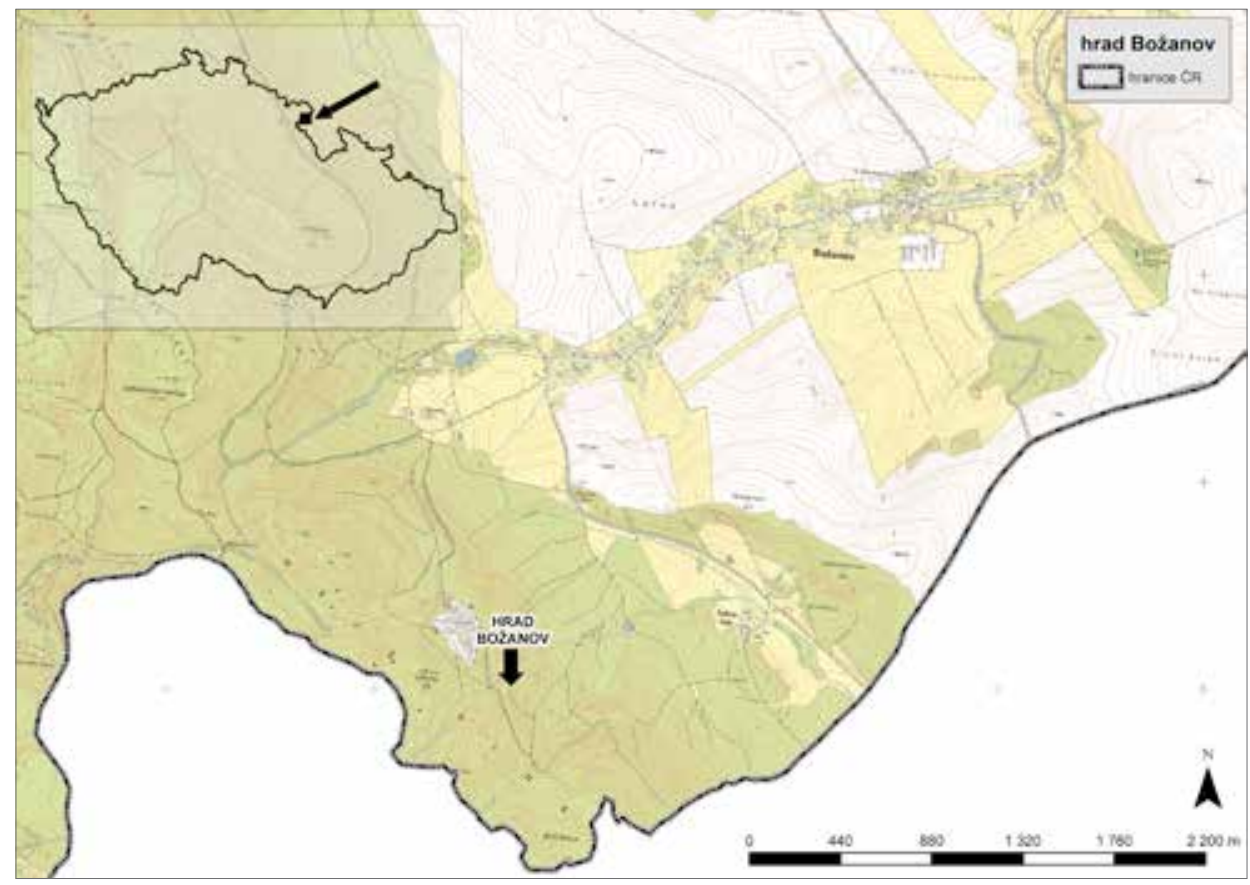

Obr. 1. Hrad Božanov. Umístění lokality v rámci České republiky a na výřezu ZM $1: 10000$.

Abb. 1. Burg Božanov. Lokalisierung der Fundstelle im Rahmen der Tschechischen Republik und auf dem Ausschnitt einer Grundkarte 1 : 10000.

a turistické literatuře. Dále jsou v urbáři zmíněny valy a nálezy dřevěných konstrukcí s kovovými prvky. ${ }^{1}$

Přŕrodní hranicí Broumovska jsou na jihu Broumovské stěny, které ho oddělují od zbytku Čech. Nejvýchodnější část těchto stěn tvoří hřbet Hejšovina, jehož severovýchodní svahy spadají do údolí vodoteče Studená, jež vytváří na svém horním toku poměrně širokou pramennou bázi s ostrou terénní hranou na severu, kterou se výrazně odděluje od zemědělského zázemí vesnice Božanov. Samotný hrad je umístěn na východní straně hřbetu Hejšovina mezi vrchy Lopota (716 m n.m.) a Bílá Skála (728 m n. m.). Poloha založení se však nenachází na vrších hřbetu, nýbrž zhruba v polovině strmého zalesněného srázu, v místech nevelké plošiny, kterou ze tří stran vymezují prŕíkré svahy.

Lokalita se nachází v zalesněném prostoru. Samotné zalesnění lze na základě ikonografických a kartografických pramenů položit s jistotou do druhé poloviny 17. století a patrně kontinuálně přes 18. století s provedeným Müllerovým mapováním Čech až do současnosti. Hospodářský les je na indikační skice i povinném císařském otisku z roku 1840 označen na katastru Božanova jako parcela 1994 náležící broumovskému klášteru. Díky kartografickým pramenům jsme schopni doložit provázanost hradní lokality se sídly v Broumovské kotlině prostřednictvím cest (ves Božanov, Studená; obr. 2, 6).

Samotná ves Božanov je příkladem kolonizačního založení a sídla, které má zástavbu podél vodního toku Božanovského potoka na výrazných širokých parcelách. Tento prvek se opakuje u okolních sídel Martínkovice, Křinice, Hejtmánkovice, Rožmitál nebo Šonov a je průvodním

1 In N. 5 ein Ort zu finden, wo vorzeiten ein von Holz erbautes Raubnest gewesen sein soll, in dem jederman noch dato die aufgwworfene Graben erkennen kann, und seind von alten Förstern in der Erden im Holz steckende grosse eiserne, bald ellenlangs eingeschlagene Nägel gefunden worden (Šmelhaus 1976, 162, § 8). 

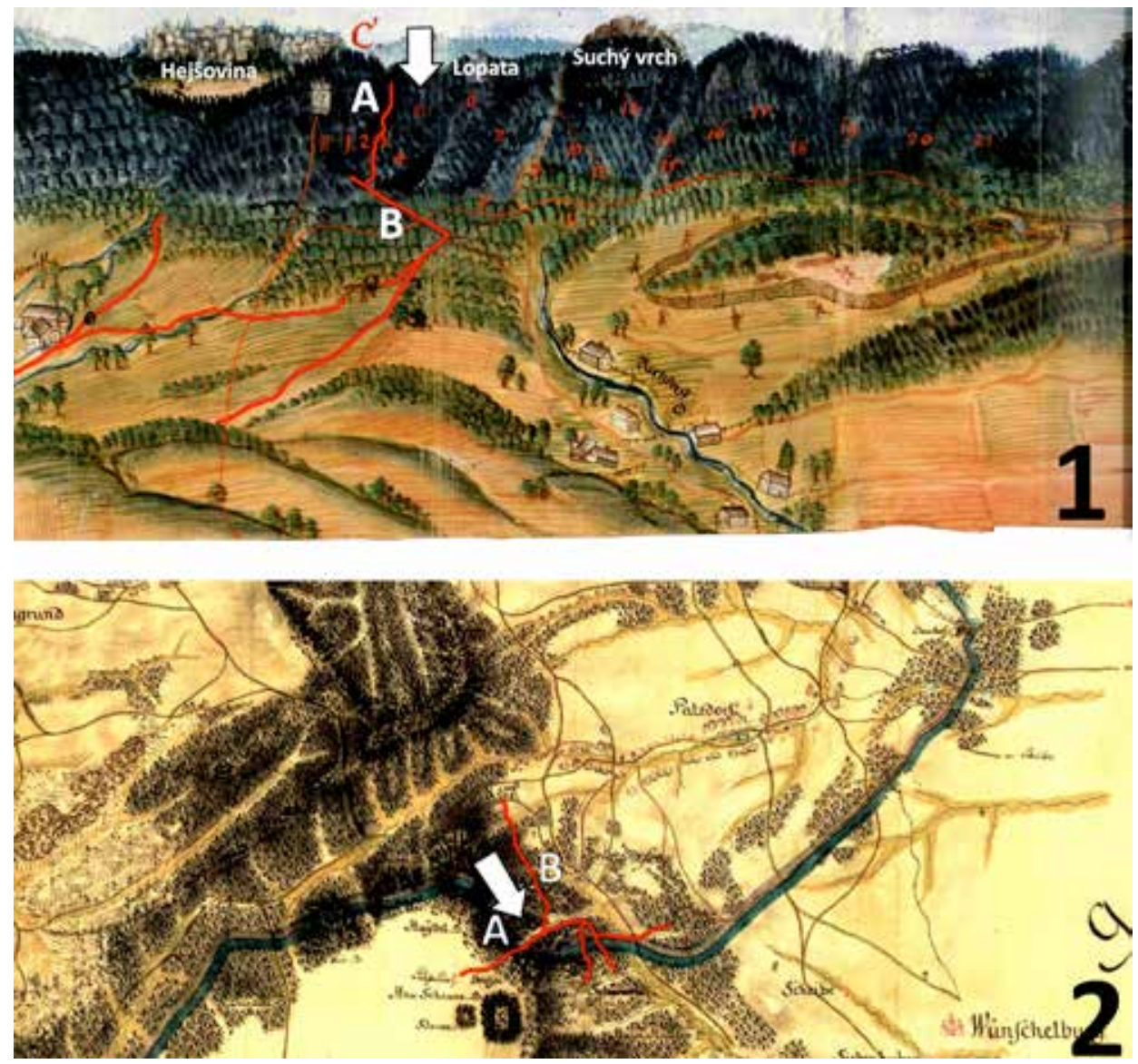

Obr. 2. Lokalita na starých kartografických dílech - Hesseliův Broumovský urbář ze 70. let 17. století (použito zobrazení podle Koláčný-Steinová-Waage 2017) a I. vojenské mapování (http://mapire.eu). 1 - pohled od severu $k$ jihu na Hejšovinu, vrch Lopata a Suchý vrch, č. 5: Raubsloss (zvýrazněno bílou šipkou), A. cesta do Pasterky, B. Cesta kolem hradu Božanova na silnici do Machova (Broumovský urbár̆, Waldkarte III); 2 - I. vojenské mapování, cesta A a B jsou vyobrazeny v Broumovském urbáři. Přibližná poloha hradu zvýrazněna šipkou.

Abb. 2. Die Fundstelle auf alten kartografischen Werken - Braunauer Urbarium von Hesselius aus den siebziger Jahren des 17. Jhdts. (Abbildung nach Koláčný-Steinová-Waage 2017) und I. militärische Kartierung (http://mapire.eu). 1 - Blick von Nord nach Süd auf die Gipfel Hejšovina, Lopata und Suchý vrch, Nr. 5: Raubschloss (mit weißem Pfeil gekennzeichnet), A. Weg nach Pasterka, B. Wege um die Burg Božanov auf der Straße nach Machov (Braunauer Urbarium, Waldkarte III); 2 - I. militärische Kartierung, die Wege A und B werden im Braunauer Urbarium dargestellt. Die ungefähre Lage der Burg ist mit einem Pfeil gekennzeichnet.

znakem vzhledu vesnického osídlení v Broumovské kotlině kodifikovaného indikační skicou stabilního katastru a v druhé polovině 17. století zakreslený do Broumovského urbáře na Horizontech II a III s variabilní zástavbou usedlostí a kostelem s ohradní zdí. První vojenské mapování zachycuje v Božanově dva mlýny (obr. 2:2).

Hrad Božanov byl zbudován na úzkém hřbetu, jehož svažitost se přirozeně a záměrně využívá jako defenzivní prvek (obr. 3). Hrad nepatř́i k druhům torzální architektury se zbytky viditelného zdiva, ale náleží $\mathrm{k}$ opevněným sídlům, ze kterých se $\mathrm{v}$ terénu dochovaly poměrně výrazné zemní relikty, i když v současném antropogenním reliéfu sídla nelze sledovat zbytky vnitřní zástavby. Hrad byl kromě severní strany obehnán př́ikopem a valem. Př́ikop dosahuje největší hloubky při jižní straně sídla, a to $3,5 \mathrm{~m}$ s maximální šířkou $8 \mathrm{~m}$. Lokalita je opevněna 


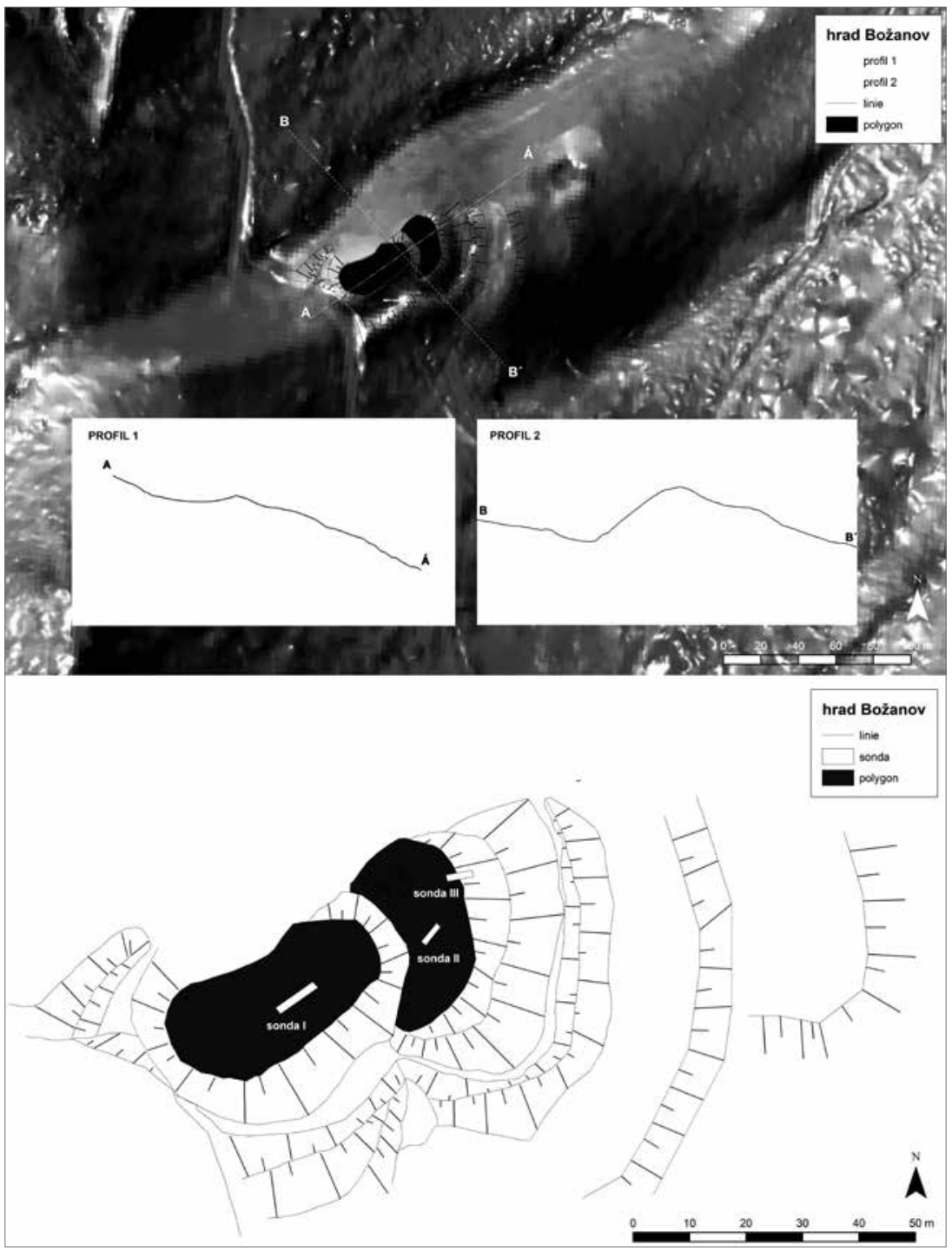

Obr. 3. Půdorys lokality doplněný o podélný a přičný profil. Doplněno o polohy sond výzkumu J. Sigla z roku 1991.

Abb. 3. Grundriss der Fundstelle ergänzt um Längs- und Querprofil. Ergänzt um die Lage der Sondierungsgrabung von J. Sigel aus dem Jahr 1991.

kombinací zemního vnějšího násypu a příkopu. Hrad se člení na dvě části. Dvoudílnost hradu se projevuje vyvýšenou centrální plošinou s obvodovým opevněním, které v části převýšení od východní plošiny chybí. Lokalita je tvořena vyvýšenou centrální plošinou s obvodovým opevněním. Centrální plošina je vymezena př́íkopem a zemním náspem. Na západní straně zemní násep chybí, nebot' za př́íkopem prochází recentní lesní cesta, kvůli které mohl být násep při jejím budování zničen. Delší osou je oválná plocha s rozměry $15 \times 43 \mathrm{~m}$ orientovaná ve směru hřbetu a převyšuje o 3,5 m východní plošinu, která má rozměry $18 \times 30 \mathrm{~m}$. Východní nižší plošina kopíruje východní svah centrální plošiny, je ledvinovitého tvaru a výrazně se rozšiřuje ve směru do 


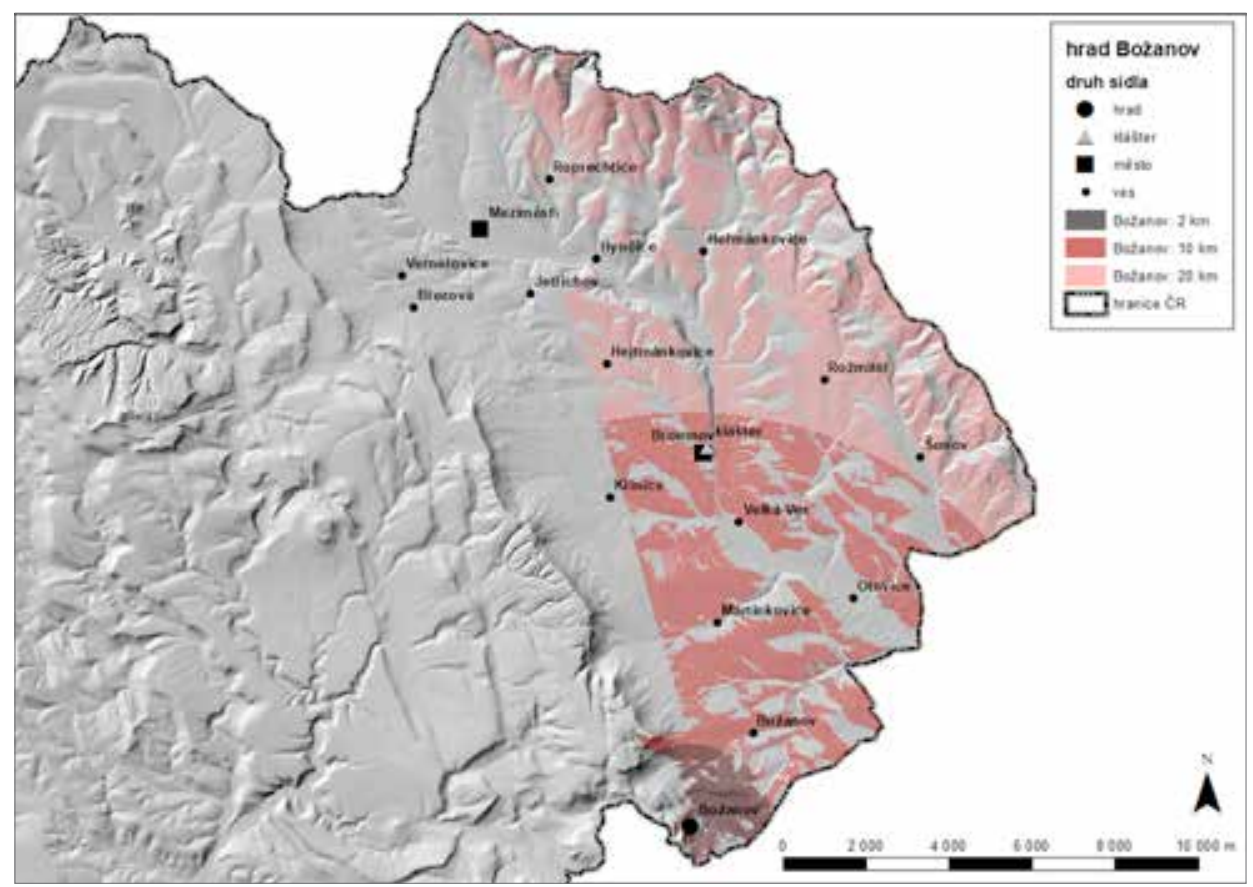

Obr. 4. Analýza viditelnosti ve studované oblasti. Dohlednost z hradu Božanov je na severozápadě silně ovlivněná Broumovskými stěnami a na severu a severovýchodě Javořími horami. V Broumovské kotlině je situace dobře přehledná a prokazuje strategicky zvolené místo pro opevnění, včetně kontroly blízkého přechodu na Radków.

Abb. 4. Sichtanalyse im untersuchten Gebiet. Die Sichtweite von Burg Božanov wird im Nordwesten stark von den Braunauer Wänden und im Norden und Nordosten vom Heidelgebirge beeinflusst. Im Braunauer Becken ist die Situation sehr übersichtlich und belegt die für eine Befestigungsanlage strategisch günstig gelegene Stelle einschließlich der Kontrolle des nahegelegenen Übergangs nach Radków.

širokého údolí potoka Studená i do úzkého údolí na jižní straně od hradu s doloženými cestami, a to k maximálnímu využití výhledu přes celou šířku hřbetu i jeho jižní svah. Se sídlem jsou východně od nižší plošiny spojitelné další dvě záměrně upravené terasy. Zároveň je východní plošina od níže položených dvou teras opět vymezená př́ikopem a valem. Vstup do opevněného areálu vedl přes jihozápadní část východní plošiny. Otázkou zůstává, jak vypadal př́istup na centrální plošinu z dolní východní plošiny.

Strategický charakter zvoleného stavebního místa lze podpořit výpočtem dohlednosti z hradu, jeho centrální i východní plošiny včetně východních valů (obr. $4,5,6)$. Dohlednost je počítána $\mathrm{z}$ dat digitálního modelu reliéfu 5. generace pro nadmořskou výšku $575 \mathrm{~m}$, ke které bylo připočteno $\mathrm{v}$ prvním případě $2 \mathrm{~m}$ navýšení a ve druhém př́ípadě $8 \mathrm{~m}$, což představuje výšku možné stavby stojící na horní plošině. Opevnění na úzkém hřbetu v kombinaci se strategicky vybranou stavební parcelou splňovalo nároky na přehlednost a kontrolu zázemí broumovského kláštera až do vzdálenosti $20 \mathrm{~km}$. Přiřazení spodních severovýchodních teras a výška valů sídla dovolovaly zvýšení komfortu dohlednosti pro nejbližší okolí do 2 až $10 \mathrm{~km}$. Celková terénní situace dovolovala kontrolovat široké území povodí Stěnavy v Broumovské kotlině v pásmu vymezeném na severovýchodě Javořími horami. Dohlednost z hradu má vysoký vojenský potenciál a zvyšuje strategickou pozici místa. Omezení dohlednosti je jen severozápadním směrem, kde výhled blokují hřbety vrchu Lopoty. Velice příhodně je kontrolován přechod do Kladska směrem na Radków. Viditelnost do 10 km zahrnuje i Broumov samotný, se kterým je přímý vizuální kontakt (obr. 5). 


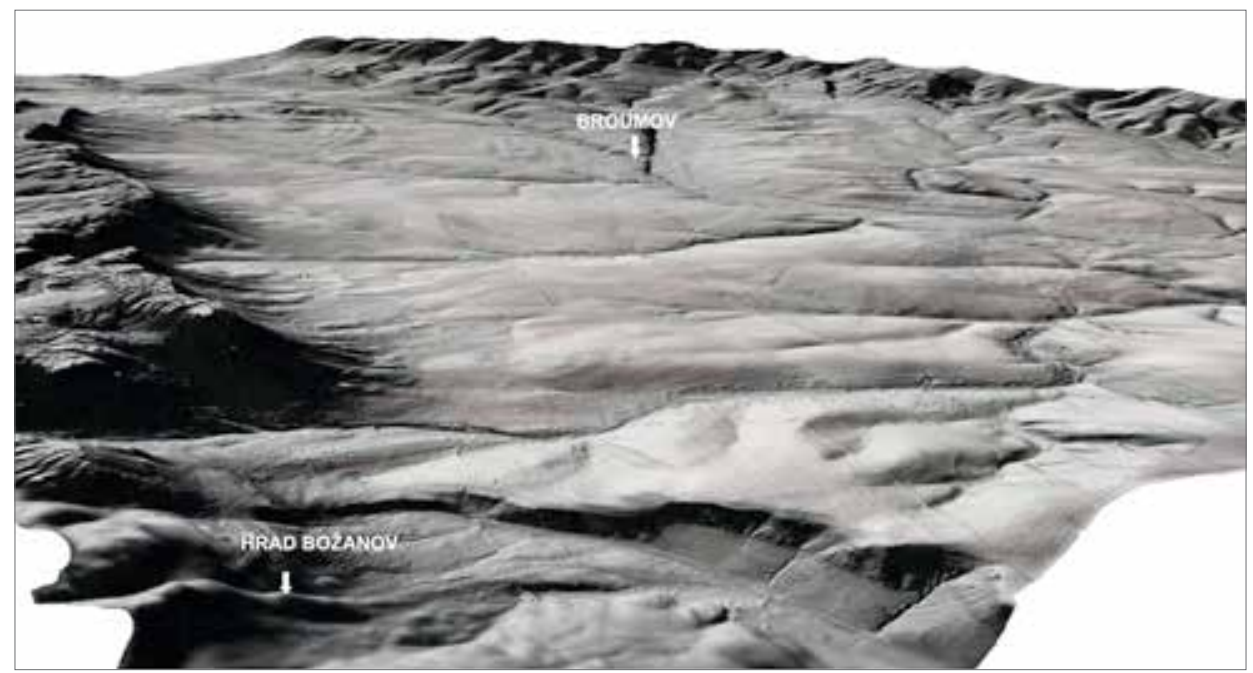

Obr. 5. Analýza viditelnosti ve studované oblasti. Porovnání dohlednosti z hradu Božanov do Broumovské kotliny s centrem v Broumově. Zdroj ČÚZK (https://ags.cuzk.cz/dmr/\#).

Abb. 5. Sichtanalyse im untersuchten Gebiet. Vergleich der Sichtweite von Burg Božanov in das Braunauer Becken mit Zentrum in Broumov. Quelle Tschechisches Amt für Landesvermessung und Kataster (https://ags.cuzk.cz/dmr/\#).

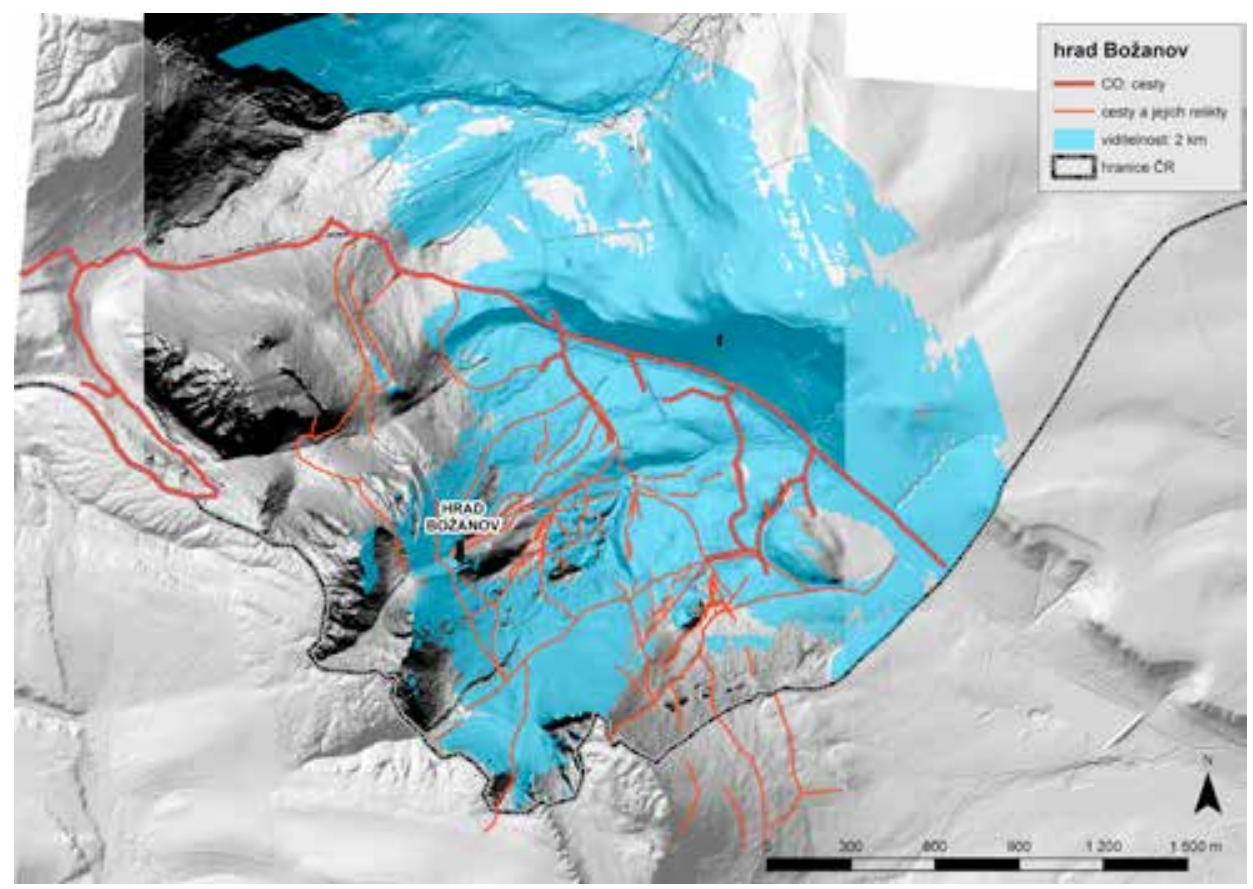

Obr. 6. Analýza viditelnosti ve studované oblasti. Viditelnost v blízkém okolí hradu Božanov. Sít' cest v zalesněném prostoru v okolí hrádku a vektorizované komunikace z Císařských povinných otisků stabilního katastru obce Božanova. Model je determinován pro výpočet hranicí ČR.

Abb. 6. Sichtanalyse im untersuchten Gebiet. Sichtweite in der nahen Umgebung von Burg Božanov. Wegenetz im waldbedeckten Raum in der Umgebung der Burg und vektorisierte Straßen aus den Kaiserlichen Pflichtabdrucken des Stabilen Katasters der Gemeinde Božanov. Das Modell ist für die Berechnung der Grenze Tschechiens bestimmt. 


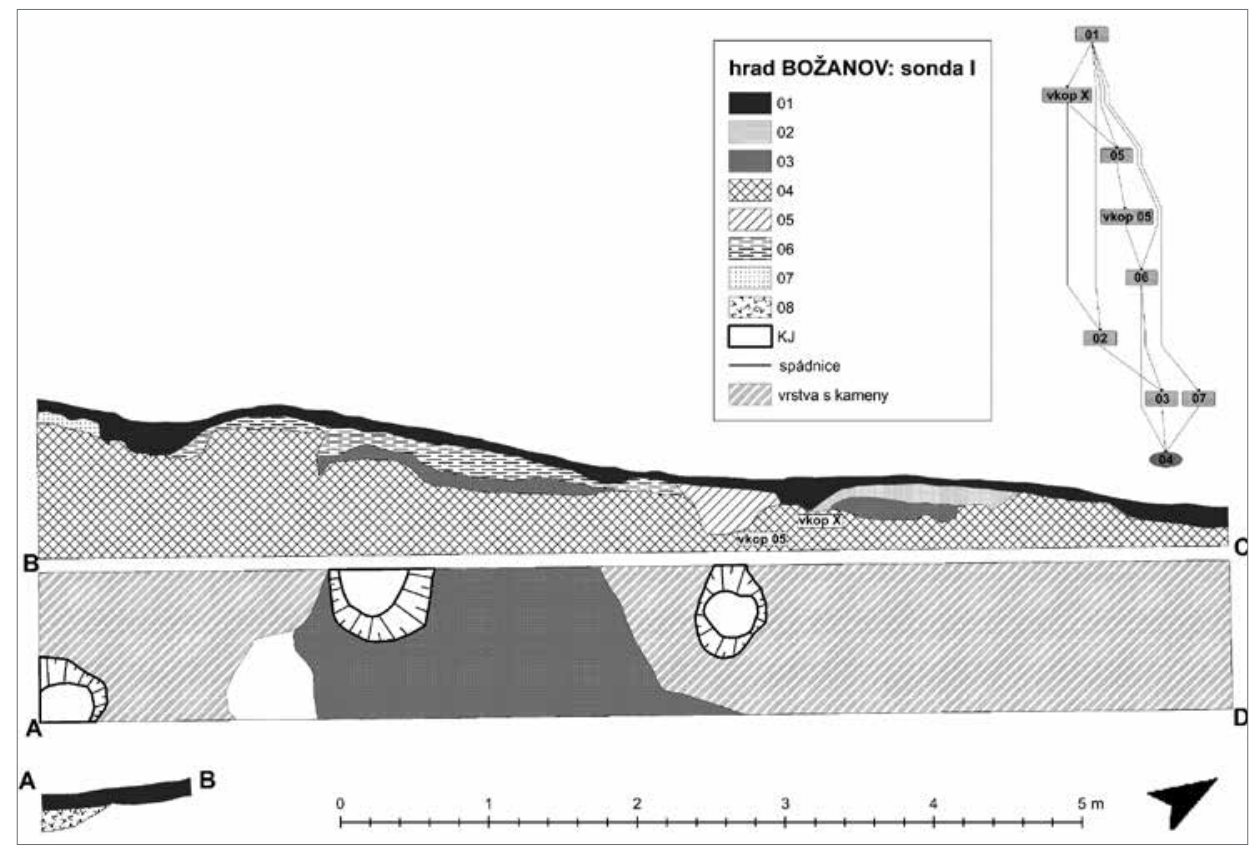

Obr. 7. Hrad Božanov. Terénní dokumentace sondy I.

Abb. 7. Burg Božanov. Geländedokumentation von Sondierschnitt I.

\section{Přehled dosavadních badatelských aktivit}

Vzhledem k tomu, že Broumovsko dlouho patřilo z pohledu archeologie mezi zanedbané oblasti, provedli první dokumentované sběry na lokalitě až Jiří Sigl a Jan Boček z tehdejšího Krajského muzea východních Čech v dubnu roku $1988 .{ }^{2}$ O dva roky později zde pak uskutečnila povrchové sběry J. Černá. ${ }^{3}$ Doposud jediný terénní odkryv, respektive zjištovací sondáž provedl J. Sigl v květnu roku 1991 (Sigl 1995, 30, pol. 124). V areálu hradu byly odkryty situace ve třech sondách (obr. 3). J. Sigl označil tyto tři sondy římskými čísly I-III. První sonda $(8 \times 1 \mathrm{~m})$ byla umístěna do vyvýšeného jádra hradu. Ve stratigrafii několika vrstev se na dně sondy objevily dvě větší kủlové jámy (průměr přes $45 \mathrm{~cm}$ ), které dokládají uplatnění dřevěných konstrukcí (obr. 7). Druhá sonda $(1 \times 4 \mathrm{~m})$ byla položena do středu plošiny pod jádrem hradu. I zde se podařilo odhalit pouze jednoduchý sled čtyř horizontálních vrstev. Na rozdíl od situace $\mathrm{v}$ jádru hradu, které mělo nízké zastoupení artefaktů, tato sonda poskytla více informací o každodennosti na lokalitě (obr. 8$)$. Třetí sonda $(1 \times 4,2 \mathrm{~m})$ byla situována na východní hranu níže položené plošiny. Byla zde zjištěna kumulace větších kamenů, kterou autor výzkumu interpretuje jako kamennou konstrukci ohrazující tento prostor od východu (Sigl 1991, 96). Ve třech horizontálně uložených a následných vrstvách byly, podobně jako v druhé sondě, objeveny četné nálezy (obr. 9). ${ }^{4}$ Sonda I doložila sídelní funkce prostoru horní plošiny sídla, která se projevila několikafázově a úpravou místa. Sonda III pak dokládá pustnutí sídla. To se projevuje v nálezu kamenné destrukce, jež leží na vrstvě, která se utvořila během využívání lokality. Zhodnocením sledu uloženin a jejich charakteru lze dospět k závěru o krátkodobém využívání lokality. Struktury

2 Získáno celkem 27 ks keramiky (př. č. 56/89). Uvedená přírůstková a inventární čísla odkazují na sbírky Muzea východních Čech v Hradci Králové, kde je dnes veškerý nalezený materiál uložen.

3 Získáno celkem 29 ks keramiky (př. č. 51/96).

4 Celkem bylo vyzvednuto 124 ks keramiky a další skupiny nálezů (př. č. 102/91). 


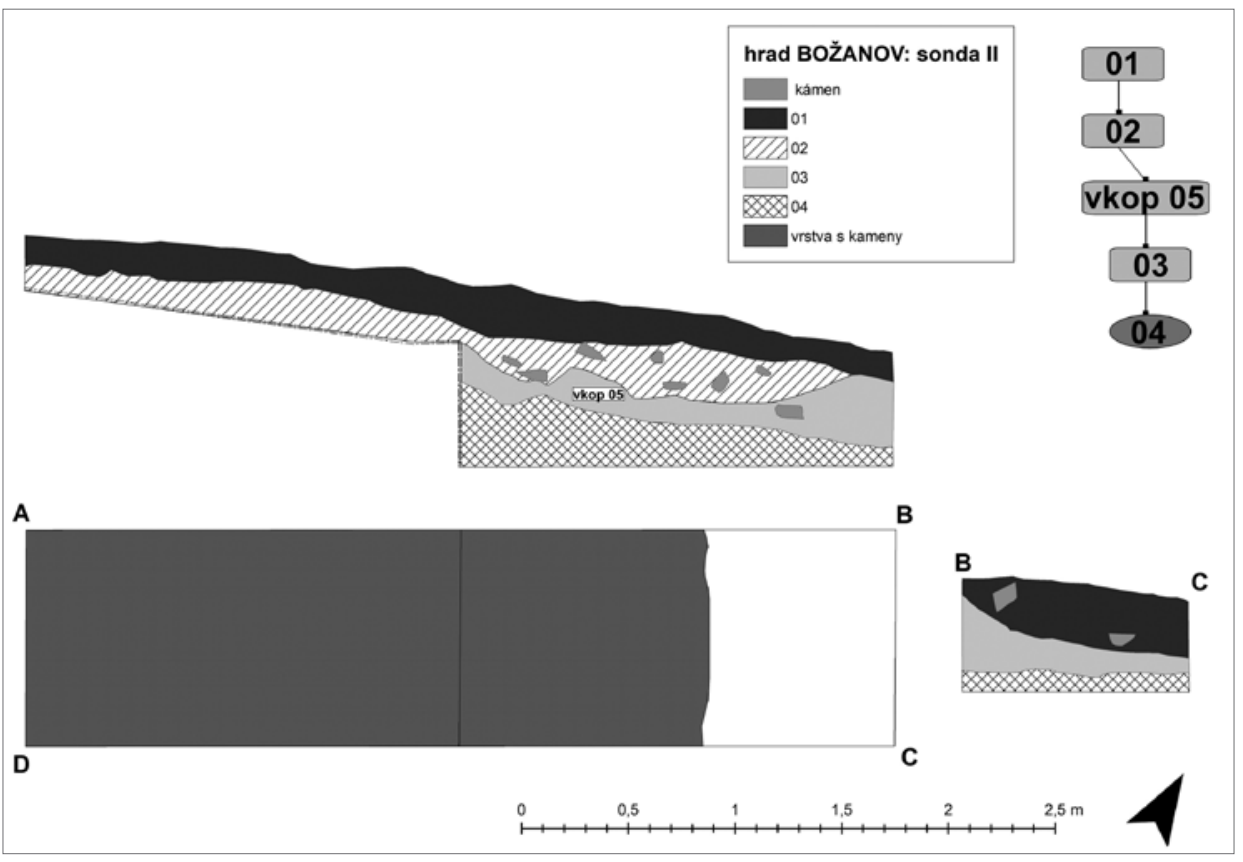

Obr. 8. Hrad Božanov. Terénní dokumentace sondy II.

Abb. 8. Burg Božanov. Geländedokumentation von Sondierschnitt II.

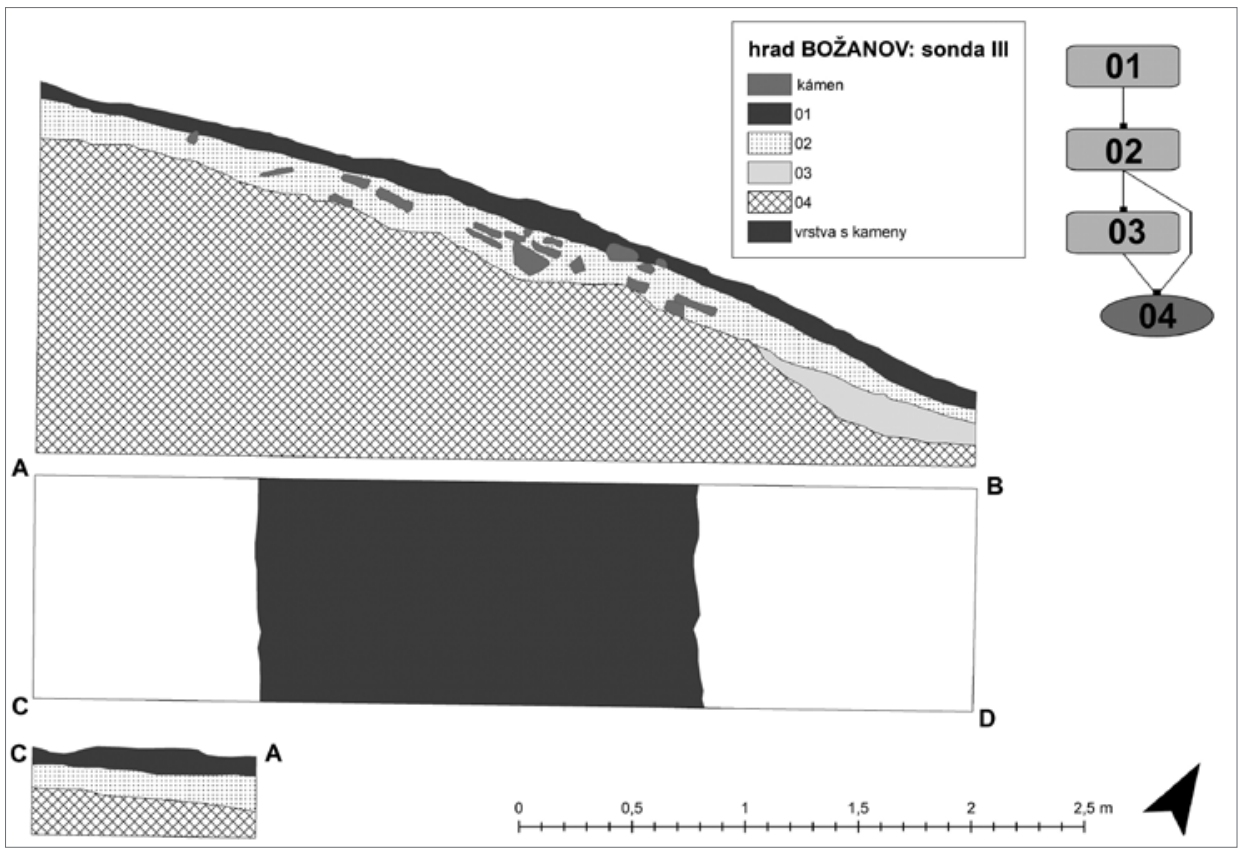

Obr. 9. Hrad Božanov. Terénní dokumentace sondy III.

Abb. 9. Burg Božanov. Geländedokumentation von Sondierschnitt III. 
zachycené v sondě I představují konstrukce využívající původní skalní podloží se záměrně provedenými jílovými vyrovnávkami. Dřevo jako stavební materiál lze doložit v podobě kůlových nebo sloupových konstrukcí. Využití nasucho kladeného kamene dokládají všechny sondy. Na obou plošinách patrně stály konstrukce kombinující dřevo a nasucho kladený kámen. Doklad vápenného pojiva na lokalitě chybí.

V průběhu roku 1993 pak J. Hlaváček na hradě objevil přes 270 kovových nálezů, které byly posléze předány do královéhradeckého muzea. ${ }^{5}$ Od průběhu 90 . let minulého století až do současnosti je lokalita častým objektem nelegálního detektorového průzkumu. Část takto nabytých předmětů se již díky komunikaci s nálezci podařilo odevzdat do královéhradecké muzejní sbírky. ${ }^{6}$

\section{Výpověd' archeologických nálezů}

\subsection{Keramické nálezy}

Nálezy fragmentů stolní a kuchyňské keramiky z výše popsaných akcí jsme se rozhodli vyhodnotit společně. K tomuto prŕístupu nás vedly skutečnosti, že většina ze všech zlomků (194ks) pochází až z terciárních uložení (včetně nálezů z výzkumu J. Sigla). Vzhledem k charakteristice souboru jsme pak upustili i od pokročilejších statistických metod či tvorby vlastního keramického typáře pro tuto lokalitu. $\mathrm{Z}$ tohoto důvodu jsme se rozhodli soubor roztřídit do tř́i keramických skupin.?

V souboru výrazně převažuje zboží pálené bez přístupu vzduchu (skupina Božanov A; obr. 10:1-20). Barva vnějšího a vnitřního povrchu i lomu se v závislosti na způsobu výpalu pohybuje v odstínech béžovošedé. ${ }^{8} \mathrm{~V}$ keramickém těstě je přítomno písčité ostřivo $(0,5-1,5 \mathrm{~mm})$, které činí povrch jemně drsným. Nejčastější keramický tvar představují hrnce a v menší míře zvonovité pokličky (obr. 10:10). Třemi zástupci jsou přítomny fragmenty konvice se třmenovým uchem a pouze jedním pak mísa (obr. 10:1, 5, 6). Okraje hrnců jsou ve formách okruží s vnějším prožlabením, dále vytažených okrajů s vnitřním prožlabením (tzv. nepravá okruží) a ovalených okrajů s vnitřním prožlabením (obr. 10:2, 3, 7, 8). Výzdoba je nejčastěji tvořena vývalkovou šroubovicí (obr. 10:4, 12-16). Řidčeji se objevuje rytá šroubovice (obr. 10:18), rytá jednoduchá vlnice, rytá vícenásobná vlnice aplikovaná na horní část okraje či rádélko (obr. 10:17). Dále lze v souboru rozlišit keramickou skupinu Božanov B (obr. 10:21-26). Zboží této skupiny bylo páleno v oxidačním prostředí, které patrně nebylo po celou dobu procesu homogenní. Díky chemismu výpalu nabývá tato hrnčina odstínů oranžové barvy (obr. 10:21-26; 19). ${ }^{9}$ V keramické hmotě je obsaženo písčité ostřivo $(0,5-1,5 \mathrm{~mm})$ a povrch keramiky tak lze označit jako jemně drsný. $\mathrm{Na}$ vrchní ploše knoflíku pokličky se dochoval otisk dřevěné desky hrnčířského kruhu (obr. 10:21). Vzhledem ke zlomkovitosti lze z pohledu typologie určit pouze několik hrnců a jednu pokličku. Zakončení hrnců jsou ve formě vytažených okrajů s vnitřním prožlabením (obr. 10:25, 26). Nádoby byly zdobeny vývalky (obr. 10:22), rytou šroubovicí (obr. 10:24) a vícenásobnou hřebenovou vlnicí kombinovanou se svazky horizontálních rýh vytvořených stejným nástrojem (obr. 10:23). Poslední keramická skupina Božanov $C$ je tvořena pouze nečetnými a většinou atypickými fragmenty (obr. 10:27-30). Keramika byla pálena za př́stupu vzduchu a její barva se pohybuje v odstínech světle béžové až světle šedobéžové barvy (obr. 12:27-30; 19). ${ }^{10}$ Podobně jako u předchozích skupin se i v této vyskytuje písčité ostřivo $(0,5-1,5 \mathrm{~mm})$, které je příčinou jemně drsného povrchu. Okraje hrnců jsou formovány do okruží (obr. 10:29, 30). Z výzdobných

\footnotetext{
5 Př. č. 77/2000, 126/2013.

6 Povrchová prospekce L. Procházky (př. č. 112/2017)

7 Osm atypických střepů nebylo pro svou různorodost přiřazeno ani k jedné ze tř́ skupin a nebylo s nimi dále pracováno.

8 10YR 5/1-3 podle Munsellova barevného systému.

9 7.5YR 7/6, 7/8 podle Munsellova barevného systému.

10 10YR 7/3, 8/4 podle Munsellova barevného systému.
} 

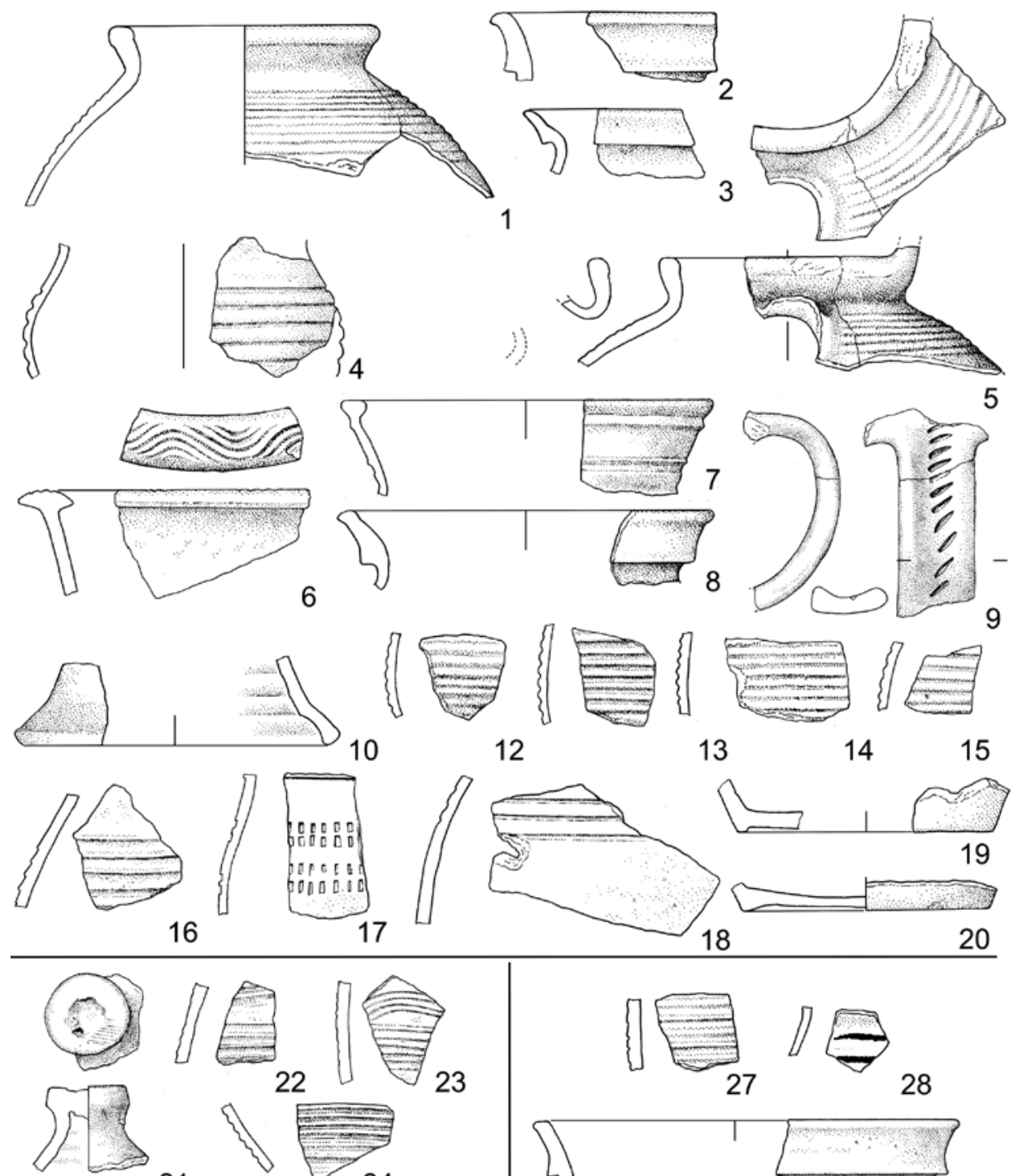

22

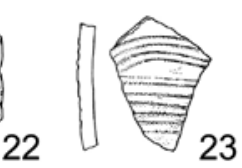

21
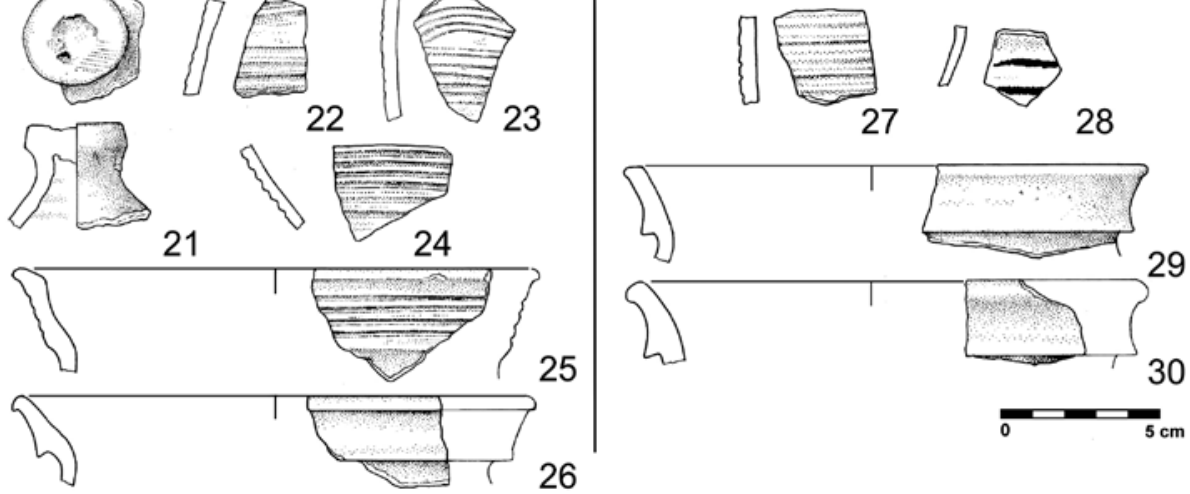

Obr. 10. Hrad Božanov. Keramické nálezy. 1-20 - keramická skupina A; 21-26 - keramická skupina B; 27-30 - keramická skupina $C$.

Abb. 10. Burg Božanov. Keramikfunde. 1-20 - Keramikgruppe A; 21-26 - Keramikgruppe B; 27-30 - Keramikgruppe C. 
prvků se objevuje vývalková šroubovice (obr. 10:27) či červené malování ve formě horizontálních linií (obr. 10:28).

Celková výpovědní hodnota keramického souboru je bohužel omezená. Důvodem je jak jeho menší velikost a povaha nálezových okolností, tak i skutečnost, že aktuální stav výzkumu vrcholně středověké keramiky východních Čech je na nedostatečné úrovni. Popisovaná kolekce stolní a kuchyňské keramiky rozdělená do tří skupin odrážejících technologické vlastnosti se vyznačuje převahou hrncovitých tvarů vytvářených vytáčením a ukončených vytaženými okraji s vnitřním prožlabením či ve formě okruží. Jako výzdobný prvek dominuje vývalková šroubovice, zastoupena je i rytá šroubovice či vlnice. Morfologicky a technologicky blízkou keramiku lze najít na několika lokalitách severovýchodních Čech. Z rozsáhlejších a publikovaných kolekcí lze uvést např́íklad nálezy z hradu Bolkova (Hejna 1962, 470-471) a Bradla (Hejna 1974, 387-393), ze starších sídlištních vrstev hradu Břečtejna (Drnovský 2018, 80-81), starší fáze tvrze v Javorníku (Drnovský 2018, 80-81), starší fáze tvrze v Mladých Bukách (Wolf 2004, 234-236), ze sídlištních vrstev trutnovské lokace (Sigl-Wolf 1983, 284-295; Wolf 2005, 94-95) či z blízkého hradu Vlčince (Horák 2002, 222-223; Novák 2004, 165-166). Výše uvedené soubory obsahující obdobnou keramiku autoři datují do časového rozmezí od průběhu druhé poloviny 13. století až po celé století následující. Do shodného chronologického rámce lze zařadit i soubor $\mathrm{z}$ hradu Božanov. Vzhledem k př́itomnosti fragmentů konvic se třmenovým uchem lze sledovanou kolekci začlenit spíše již do závěru 13. století či prvních decennií 14. století (Richter 1982, 76; Klápště 1998, 156; 2002, 19-21).

\subsection{Kovové nálezy ${ }^{11}$}

Kolekci kovových nálezů pocházející z výzkumu J. Sigla a artefakty získané za pomoci detektoru kovů (odevzdané do královéhradeckého muzea) jsme pro potřeby zpracování roztrŕídili dle používaných kategorií odvozených od jejich předpokládané funkce. Kvalita informací získaných při detektorové prospekci kolísala. U většiny kovových artefaktů nebyla známa poloha a původní hloubka uložení nebo popis případné vrstvy. ${ }^{12}$ Jen některé $\mathrm{z}$ artefaktů získané detektorem kovů měly koordináty GPS..$^{13}$

\subsubsection{Stavebni kování, součásti provozního vybavení}

Nejhojnější nálezy, jež lze dát do souvislosti s dřevěnými konstrukčními prvky, představují hřebíky ( 47 ks), které obecně patří mezi nejčastěji nalézané železné artefakty na středověkých lokalitách. Tato skutečnost společně s jejich nevýraznou chronologickou citlivostí má za následek, že bývají v soudobých pracích opomíjeny či zhodnoceny pouze stručně. Soubornější deskripce a vyhodnocení se tak dočkaly pouze nálezy pocházející z rozsáhlejších výzkumů, jakými byly např́klad Kartouzka v Dolanech (Burian 1979, 25-31), Mikulčice (Klíma 1975, 140-150), Konůvky (Šaurová 1978, 560-566), Mstěnice (Nekuda 1985, 148-152) nebo Sezimovo Ústí (Krajíc 2003, 61-74). Právě terminologii a třídění vycházející z nálezů z posledně jmenované lokality lze na náš soubor hřebíků aplikovat. Nejčastěji jsou zastoupeny hřebíky bez hlavy, tzv. klínce (56ks). Pro tento typ (VIII) hřebíků lze na řadě lokalit sledovat nápadnou koncentraci v destrukčních vrstvách staveb, což odráží způsob jejich využití (Krajíc 2003, 67-67). Několika jedinci jsou př́itomny i hřebíky s tenkým dříkem a lopatkovitě rozšsiřenou vertikální hlavou (typ Vc, 18 ks). Tyto výrobky bývají většinou dávány do souvislosti s upevňováním dřevěných šindelů, od čehož je odvozeno i jejich alternativní pojmenování jako šindelové (př́ípadně šindeláky). Většina hřebíků pochází z kontextů sondy II a III výzkumu J. Sigla, naopak v kolekcích vzešlých z detektorového průzkumu se téměř nevyskytují, což souvisí se záměrnou selekcí nálezů během prospekce.

11 Jednotlivé kovové nálezy budeme pro přehlednost označovat číslem sáčku dle evidence královéhradeckého muzea a písmenem $B$. Tyto hodnoty jsou používány i pro identifikaci jednotlivých artefaktů v rámci kresebné dokumentace.

12 Sběry J. Hlaváčka roku 1993 lokalizované pouze na opevněné jádro fortifikace.

13 Sběry L. Procházky roku 2017 (B 190-B 200, B 202). 

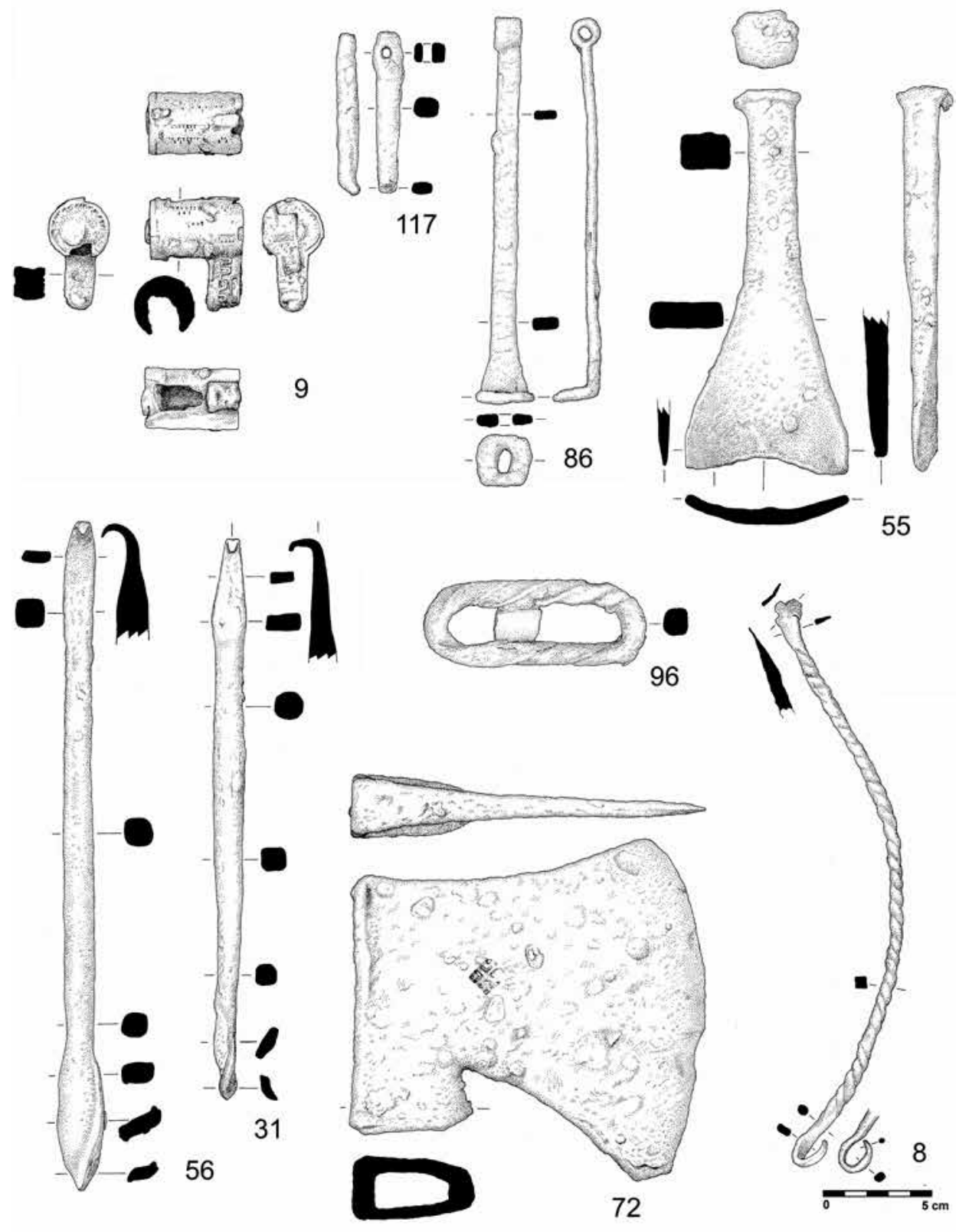

Obr. 11. Hrad Božanov. Stavební kování, součásti provozního vybavení. Číslování odpovídá označení kovových artefaktů v textu.

Abb. 11. Burg Božanov. Baubeschläge, Bestandteile der Betriebsausstattung. Die Nummerierung entspricht der Kennzeichnung der Metallartefakte im Text. 
Z kovových součástí uzavíracích mechanismů pochází z lokality po jednom exempláři závěsný zámek, klíč a závlačka. Ze závěsného svorníkového zámku se dochovala pouze jeho zámková část (B 9; obr. 11). Svými rozměry (délka těla $45 \mathrm{~mm}$, výška $52 \mathrm{~mm}$ ) je srovnatelný s nálezy tohoto typu zámku z jiných lokalit. Od těchto exemplářů se odlišuje výzdobou v podobě vyražených drobných trojúhelníků řazených do vodorovných linií na těle zámku. Pravá dochovaná bočnice je pak zdobena plastickou klikaticí. Všeobecně se jedná o typ zámku, jenž je běžně přítomen na vrcholně středověkých lokalitách $\mathrm{v}$ různých sociálních prostředích, s těžištěm výskytu zejména ve 14. a 15. století (Krajíc 2003, 83). Z východočeských analogií je možno uvést nálezy zámků z Červené Hory (Drnovský 2018, 152, obr. 201:1), Semonic (Huml 1967, 21, 26, tab. II:8, VII:1, 3), Vízmburku (Hejna 1983, 494-495, obr. 4:6) či Vildštejna (Durdík-Frolík 1993, 58, obr. 19:8). Jediný nalezený klíč (B 86; obr. 11) lze zařadit mezi zásuvné asymetrické typy. Tělo klíče, které má obdélný průřez, je na svrchní straně ukončeno kruhovým očkem, na druhé pak obdélným zubem s vnitřním otvorem. Celková délka klíče činí $172 \mathrm{~mm}$. Tento typ klíčů, sloužících k otevírání zámků pružinové konstrukce, patří k obvyklým výrobkům. Jejich používaní je doloženo na řadě vrcholně stř̌edověkých lokalit, a to ze situací, jež lze datovat do období 13. až počátku 16. století, přičemž doba jejich hlavní produkce bývá vymezována zejména do průběhu 13. a 14. století (Krajíc 2003, 90). Pro tento časový horizont lze uvést analogie např́íklad z Červené Hory (Drnovský 2018, 152, obr. 201:9), Mstěnic (Nekuda 1985, 157-158, obr. 212:a), Semonic (Huml 1967, 26, tab. IV:16) či Sezimova Ústí (Krajíc 2003, 90). S uzavíráním dveří je pak spjat i nález závlačky (B 117; obr. 11), která byla zhotovena ze železné tyčinky oválného průřezu. Na jednom z konců je mírně rozšiřena a zároveň je zde proražen otvor sloužící k provléknutí řetízku či provázku. Závlačka pak sloužila k zajištění petlice či oka s trnem.

Předmět zhotovený z tordovaného železného prutu čtvercového průřezu lze patrně určit jako pozůstatek držadla vědra (B 8; obr. 11). Jeden z konců držadla se dochoval v původní podobě a je tvořen rozklepáním prutu do závěsného oka, které sloužilo ke spojení s bočním kováním vědra. Celkové rozpětí držadla je $257 \mathrm{~mm}$, prohnutí ramen pak činí $49 \mathrm{~mm}$. Nízkou hodnotu vyklenutí držadla lze patrně přisoudit deformaci vzniklé při archeologizaci předmětu. Nálezy držadel dřevěných nádob nebývají pro období vrcholného středověku časté. Ze zánikového horizontu Sezimova Ústí pochází kompletní exemplář (Krajíc 2003, 200-201), doplněný však o otvor pro úchyt, obdobně je řešeno i držadlo z Vildštejna z rozmezí 13.-15. století (Durdík-Frolík 1993, 58, obr. 22:1). Držadlo vědra nalezené na Hradišt'ku u Davle je zhotoveno z obyčejného kovového plátu s obdélným profilem (Richter 1982, 181, obr. 130:2). Analogické provedení k držadlu z Božanova pochází z Hradce Králové - Velkého náměstí (Richter-Vokolek 1995, tab. 119:6, 120:6). Mezi nálezy sloužící jako součást provozního vybavení lze zařadit i kompletní tordovaný článek řetězu (B 96; obr. 11). Je pravděpodobné, že část blíže neurčených amorfních zlomků, kterými se dále nezabýváme, rovněž pochází z různých článků řetězů.

\subsection{2 Řemeslnické nástroje a zemédělské nářadi}

V kolekci nálezů lze rozeznat celkem čtyři zástupce srpů (obr. 12). Dva exempláře se dochovaly v téměř celistvé podobě. První srp (B 188) má celkovou délku $411 \mathrm{~mm}$, přičemž délka řapu rukojeti činí $88 \mathrm{~mm}$. Druhý srp (B 189) je nepatrně menší (392 mm), oproti tomu má výrazně delší řap rukojeti $(118 \mathrm{~mm})$. Maximální výška pravidelných obloukovitých čepelí obou srpnů je srovnatelná $(55$ a $50 \mathrm{~mm})$. Ze třetího srpu se dochoval řap držadla $(127 \mathrm{~mm})$ a kus obloukovitě tvarované čepele (B 183). Poslední nález je tvořen pouze částí čepele (B 182). Oba celistvější srpy lze přiřadit k typu I podle R. Krajíce (2003, 140), respektive typu d1 dle M. Beranové (1957, 104-105). Opět se jedná o častý nález, běžný pro venkovské prostředí, doložený však i v areálech městských aglomerací či na opevněných sídlech. Srpy mají osu předmětu (prodloužení řapu rukojeti) s nízkým obloukem čepele, který je stlačený k rukojeti, a přesahujícím hrotem čepele za osu artefaktu. Z východočeských opevněných lokalit horizontu 13.-15. století lze uvést např́íklad Batňovice (Lochmann 1989, 107, tab. 3:7), Bolkov (Hejna 1962, 465, obr. 6), Bradlo (Hejna 1974, obr. 13:20), Červenou Horu (Drnovský 2018, 156, obr. 204:3-5), České Libchavy (Vích 

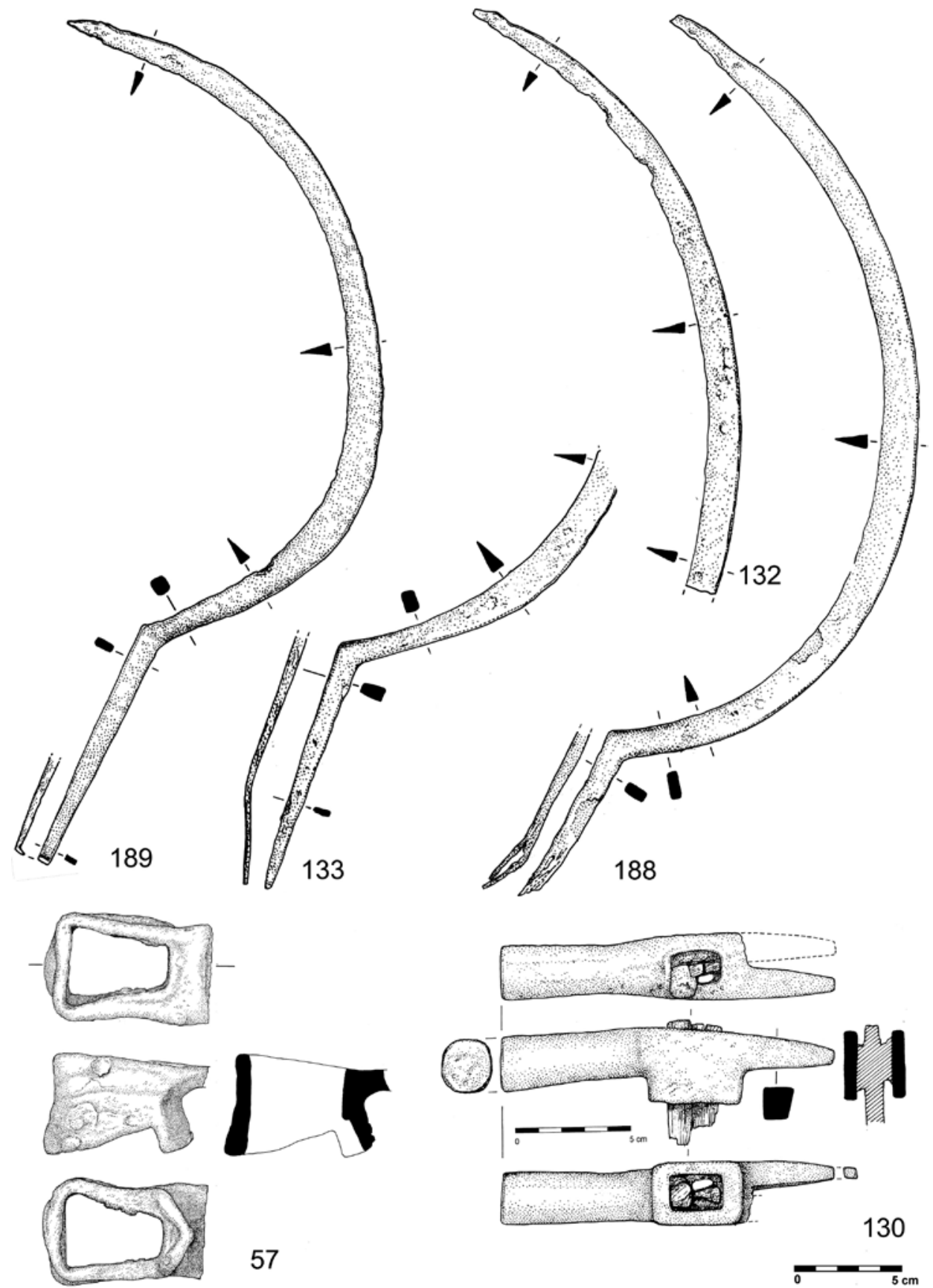

Obr. 12. Hrad Božanov. Srpy, motyka, kladivo. Číslování odpovídá označení kovových artefaktů v textu.

Abb. 12. Burg Božanov. Sicheln, Hacke, Hammer. Die Nummerierung entspricht der Kennzeichnung der Metallartefakte im Text. 
2015, 171, obr. 9:3), prostor fortifikace v předpolí hradu Lanšperka (Vích 2010, obr. 10:1-6; 338; 2016, 329, obr. 3:5-8), Semonice (Huml 1967, 38-39, tab. I:8-12) nebo Vízmburk (Mazáčková 2013b, 163, tab. 70:2).

Z motyky (B 57; obr. 12) se dochovala pouze týlní část s tulejkou a náběhem počínajícího těla. Přední část tuleje je doplněna o železný pás sloužící k dokonalejšímu nasazení dřevěné násady a př́ípadně i $\mathrm{k}$ její ochraně proti odírání při práci. Identickou ochranu násady mají motyky objevené v Sezimově Ústí (Krajíc 2003, 137; zde typ Ic), Hrádníkách u Zářecké Lhoty (Vích 2016, 148, obr. 18:1), obléhacím táboře u hradu Lichnice (Frolík-Musil 2013, 157, obr. 24:1) a Semonicích (Huml 1967, 10, obr. II:3). Úzké a robustní motyky (lidově též klučovnice) se uplatnily při široké škále činností. Mohly být používány jako krumpáče k dobývání pařezů, kořenů nebo k narušování pevné hlíny či měkčích hornin, alternativně i k okopávání záhonů, $\mathrm{k}$ tomuto však byly využívány spíše motyky se širokým tělem. Vzhledem k univerzálnosti jejich užití se jedná o nástroje s dlouhým časovým výskytem a nevelkou možností bližšího chronologického zařazení.

K řemeslným nástrojům patří nález sekery s prodlouženou tulejí (B 72; obr. 12). Sekera vážící $1034 \mathrm{~g}$ dosahuje celkové délky $164 \mathrm{~mm}$. Maximální šíře tulejky činí $56 \mathrm{~mm}$, přičemž výška rovného týlu je $119 \mathrm{~mm}$. Vějírovité symetrické ostř́i, které je mírně ve spodní části protáhnuto, má celkovou délku $158 \mathrm{~mm}$. Na pravé straně v přechodu mezi tulejí a tělem je vyražena čtvercová kovářská značka. Ačkoliv nemá sekera natolik výrazně vytaženou tulejku, lze ji podle tvaru přiřadit ke skupině seker typu X podle M. Głoska (1996, 43-46), který jejich výskyt klade do širokého rámce 13.-16. století. Četné exempláře z domácích i cizích lokalit tomuto určení odpovídají a bližší chronologické zařazení je tak obtížné. $Z$ domácích analogií lze uvést například lokality Koválov (Unger 1994, 24, obr. 17:7), Lelekovice (Unger 1999, 123, obr. 135:1) a Semonice (Huml 1967, 67, tab. IX:1).

K práci se dřevem pak obyvatelům sídla též posloužily nebozezy, které jsou v nálezovém souboru zastoupeny dvěma exempláři (obr. 12). První nebozez (B 31) je dlouhý $249 \mathrm{~mm}$ a bylo s ním možné vytvořit otvor o průměru $16 \mathrm{~mm}$. Druhý nebozez (B 56) je nepatrně delší ( $296 \mathrm{~mm}$ ), čemuž odpovídá i větší průměr vrtného hrotu $(23 \mathrm{~mm})$. Oba nástroje mají dříky čtvercového průřezu. Shodují se i v řešení rukojeti, respektive způsobu uchycení dřevěné násady. Konce dř́ků jsou roztepány do trnu s obdélným průřezem, který byl zaražen do dřevěné násady. Menší nebozez má dobře patrné sklepání a ohnutí vyčnívající části trnu okolo násady. Tento typ nástrojů představuje běžný nález na středověkých lokalitách a jejich funkční tvar znamená, že se jedná o méně chronologicky citlivé nástroje. Z českých a moravských situací je máme bezpečně zastoupeny již pro období 13. století (např. Žákovský-Hošek 2016, 244). Za všechny př́íklady nálezů v prostředí fortifikovaných sídel lze uvést východočeské lokality Bolkov (Hejna 1962, 468), Bradlo (Hejna 1974, 498), Červenou Horu (Drnovský 2018, 153-154, obr. 205:3-6), Semonice (Huml 1967, 21, tab. V:1-6), prostor fortifikace v předpolí hradu Lanšperka (Vích 2016a, 328, obr. 5:2-3), Orlík u Brandýsa nad Orlicí (Vích-Žákovský 2016, 317, obr. 35:68) či Vízmburk (Mazáčková 2013b, 162, tab. 69, 1-2).

Jedním nálezem je v kolekci zastoupeno kladivo (B 130; obr. 12), objevené během výzkumu J. Sigla. Jedná se o exemplář s rozdvojeným nosem a kruhovým profilem čepce. V oválném oku nástroje je dochovaný hřeb, který napomáhal zajišt'ovat dřevěné topůrko. Tento druh kladiv je v literatuře spojován se specializovaným využitím, např́íklad při ševcovském (Měchurová 1995, 149), zámečnickém (Krajíc 2003, 164-165) nebo kovářském provozu (Belcredi 1988, 474); je doložen již v průběhu 13. století, a to např́íklad na Hradišt'ku u Davle (Richter 1982, 172, obr. 122). Z analogických nálezů lze uvést př́klady z Bystřece (Belcredi 1988, 478, obr. 11:E), Červené Hory (Drnovský 2018, 155, obr. 202:4-5), Konůvek (Měchurová 1995, 149-150, tab. 4:9), Sezimova Ústí (Krajíc 2003, 164, tab. 133), prostoru fortifikace v předpolí hradu Lanšperka (Vích 2016a, 148, obr. 5:12) či Sionu - obléhacího tábora (Koscelník-Kypta-Savková 2013, 11, obr. 6:306). Exemplář z Božanova se oproti těmto kladivům vyznačuje robustností (váha $423 \mathrm{~g}$ ), a tedy i potenciálně vyšší úderností. 
Neobvyklý nález představuje kompletní tvar dláta (B 55; obr. 12). Pod tímto pojmem bývají v literatuře nejčastěji označovány zejména delší nástroje tyčového charakteru ukončené ostřím (Krajíc 2003, 154-155). Někteří autoři pak téměř shodné exempláře označují jako sekáče (např. Huml 1967, 21; Slivka 1981, 217). ${ }^{14}$ Z pohledu současné terminologie pracovních nástrojů se jeví jako vhodnější používat termín dláto spíše pro kratší nástroje určené ke specializovaným řemeslným činnostem (tesařské, kamenické), zatímco pro delší tyčovité nástroje je vhodnější používat název sekáč. Božanovský nález je tak možno s jistotou označit jako dláto. Tělo (dřík) dláta je tvořeno železnou tyčovinou obdélného průřezu, která byla na svém konci rozklepána do rozšiřujícího se ostří, které je navíc mírně prohnuté. Úderová (týlní) část těla nose stopy po použivání ve formě rozklepání. Vzhledem k celkové masivnosti $(420 \mathrm{~g})$ a charakteru šířky a úhlu ostř́i se jedná patrně o půlkulaté dláto sloužící k opracování kamene. Dláta s takto tvarovaným ostřím bývají dodnes vyráběna a slouží zejména při vytesávání žlabů či koryt. Nálezy kamenických dlát jsou vzácné, proto bývají typy a tvary středověkých nástrojů odvozovány podle ikonografických pramenů a zejména pak podle zanechaných pracovních stop na opracovaném kameni (srov. Chotěbor 1993; Cihla-Panáček 2006; 2011).

Z kolekce kovových nálezů pocházejících z výzkumu J. Sigla a z artefaktů získaných za pomoci detektoru kovů a odevzdaných do královéhradeckého muzea patř́ mezi chronologicky citlivé nálezy zejména součásti výstroje jezdce a koně, militaria, monetární nálezy a nákončí opasku.

\subsubsection{Výstroj jezdce a koně}

Mezi chronologicky citlivé nálezy patří ostruhy, ty jsou zastoupeny jedenácti exempláři (šest celistvěji dochovaných jedinců, dva fragmenty a tři přezky; B 1-5, 171, 197; obr. 13). Ostruhy mají společný tvar s krátkým rozeklaným krčkem pro upevnění hvězdice, který je rozdělený až k patnímu oblouku spojujících se ramen ostruhy. Krček se směrem od patního oblouku k otvorům pro nasazení osy s hvězdicí výrazně zužuje. Patní část ostruhy je zvýrazněná vytaženým lomeným obloukem. Výrazně obloukově prohnutá ramena jsou ukončena na střed osy kruhového zakončení pro upevnění garnitury. Průřez ramen odpovídá komfortnímu upevnění k noze jezdce, vnitřní strana je plochá a vnější strana má středovou hranu pro zpevnění ramene proti deformaci. Božanovské ostruhy se řadí k typu Hilczerówna III s datací od druhé poloviny 13. století až počátku 14. století, podle Kołodziejského třídění se jedná o typ A s datací ve druhé polovině 13. století až první čtvrtině 14. století, podle T. Drobného se jedná o typ 3 z první poloviny 14. století, A. Ruttkay řadí tuto formu k typu C a podle A. N. Kirpičnikova lze artefakt prriřadit ke tvaru V. Na základě nejnověji publikovaného tř́idění ostruh od P. Koóšové se forma hlásí do průběhu 13. a 14. století (Kirpičnikov 1973, 67-68; Ruttkay 1976, 350-352; Drobný 1995, 108-110; Kołodziejski 1985, 165; Hilczerówna 1956, 63-69; Koóšová 2004, 530-536).

Ze stratifikovaných a datovaných analogií lze uvést soubor ostruh z hradu Veselí nad Moravou, který vykazuje stejné charakteristiky jako božanovské ostruhy (Žákovský 2015, 232-234). Další analogie z archeologických situací představují nálezy z prvního zánikového horizontu hradu Rokštejna, který je spojený s vojenskou akcí doprovázenou pobitím posádky a požárovým horizontem, který se odehrál před roky 1306-1307. Jedná se o dva exempláře ostruh (inv. č. A 5496, D 4654; Mazáčková 2013a, 264, fig. 7:A 5496, D 4654). Ostruha stejného typu pochází i z výzkumu hradu Bolkova s chronologickým zařazením existence lokality podle kovového i keramického materiálu na přelom 13. a 14. století (Hejna 1965, 457, 471, obr. 1:6; Jansa 2006, 33). Další obdobné ostruhy jsou z Hradišt'ka u Davle (Richter 1982, 164, obr. 108:1, 3, 4, 6). Z územně blízkých analogií lze doplnit i ostruhy z Červené Hory založené v průběhu 13. století (Drnovský 2018, 158, obr. 207, 1, 3).

Pouze ostruha B 198 náleží ke zcela jiné a časově mladší formě, je poškozena korozí a má odlomené levé rameno. Na pravém rameni zůstalo silně poškozené ukončení s nečitelným formováním úchytů. Jedná se o tvar s rameny $\mathrm{v}$ jedné rovině bez prohnutí pro kotník, protože

14 K problematice uživání termínu dláto a sekáč např. Belcredi 1989, 450, a Krajíc 2003, 154-155. 

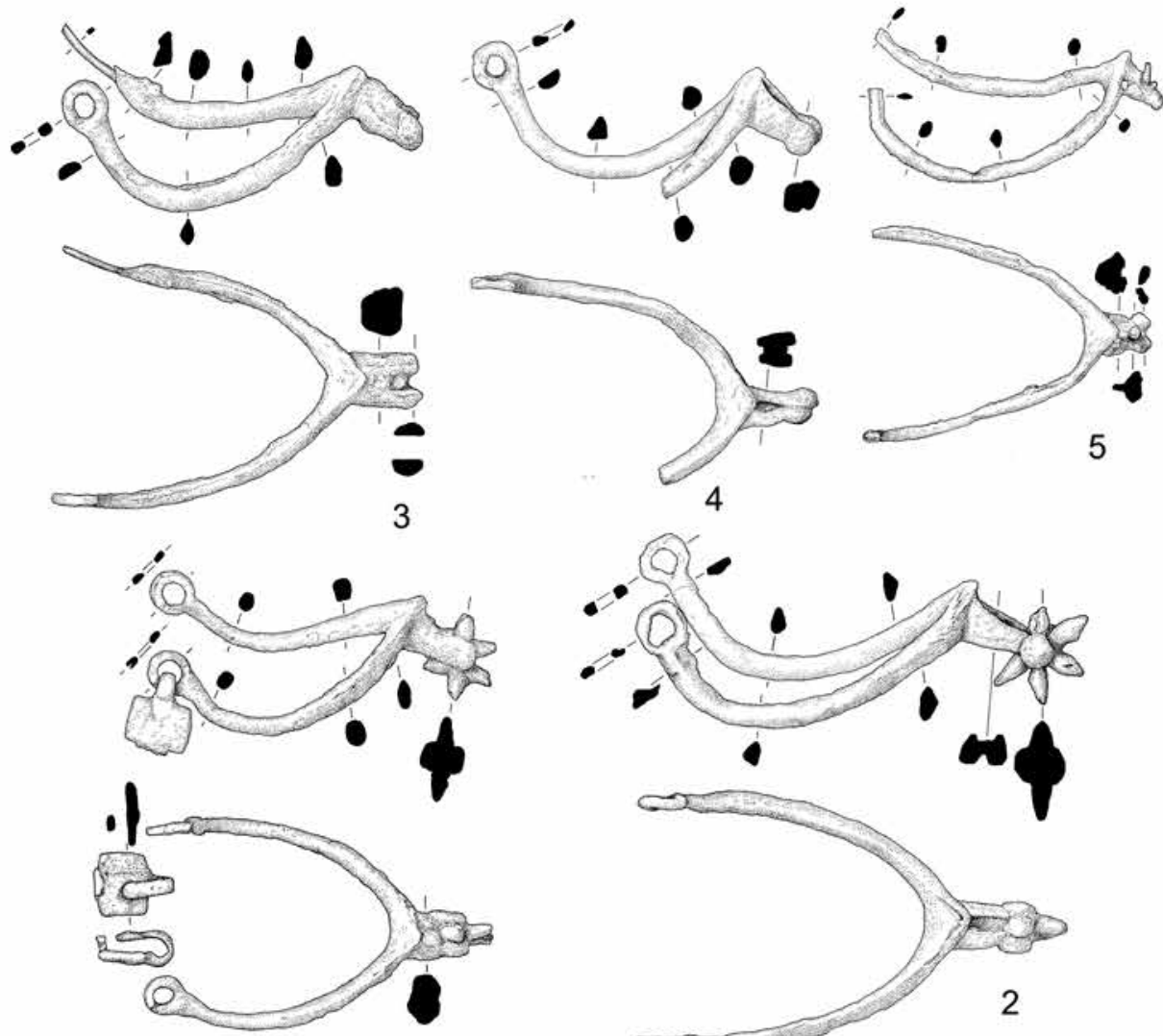

1
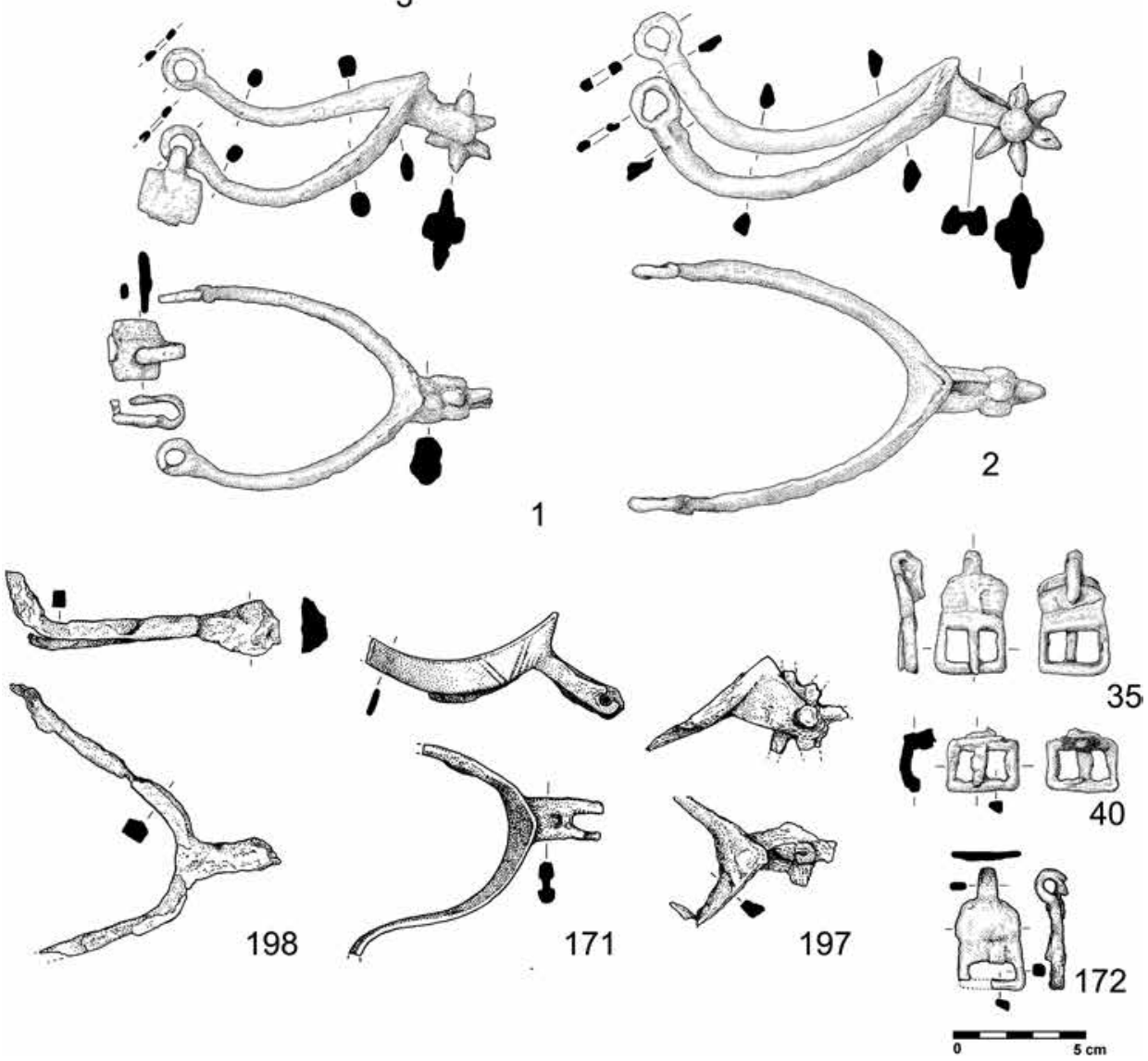

Obr. 13. Hrad Božanov. Ostruhy a jejich součásti. Číslování odpovídá označení kovových artefaktů v textu.

Abb. 13. Burg Božanov. Sporen und ihre Bestandteile. Die Nummerierung entspricht der Kennzeichnung der Metallartefakte im Text. 

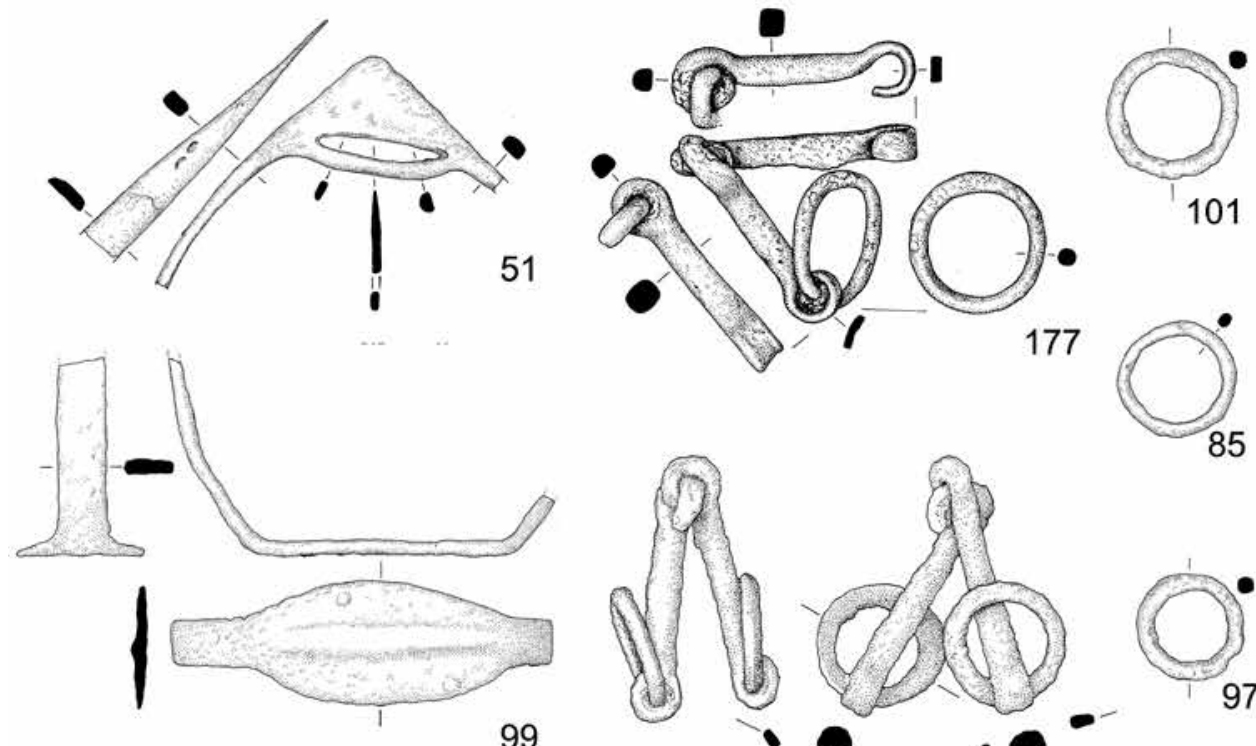

177
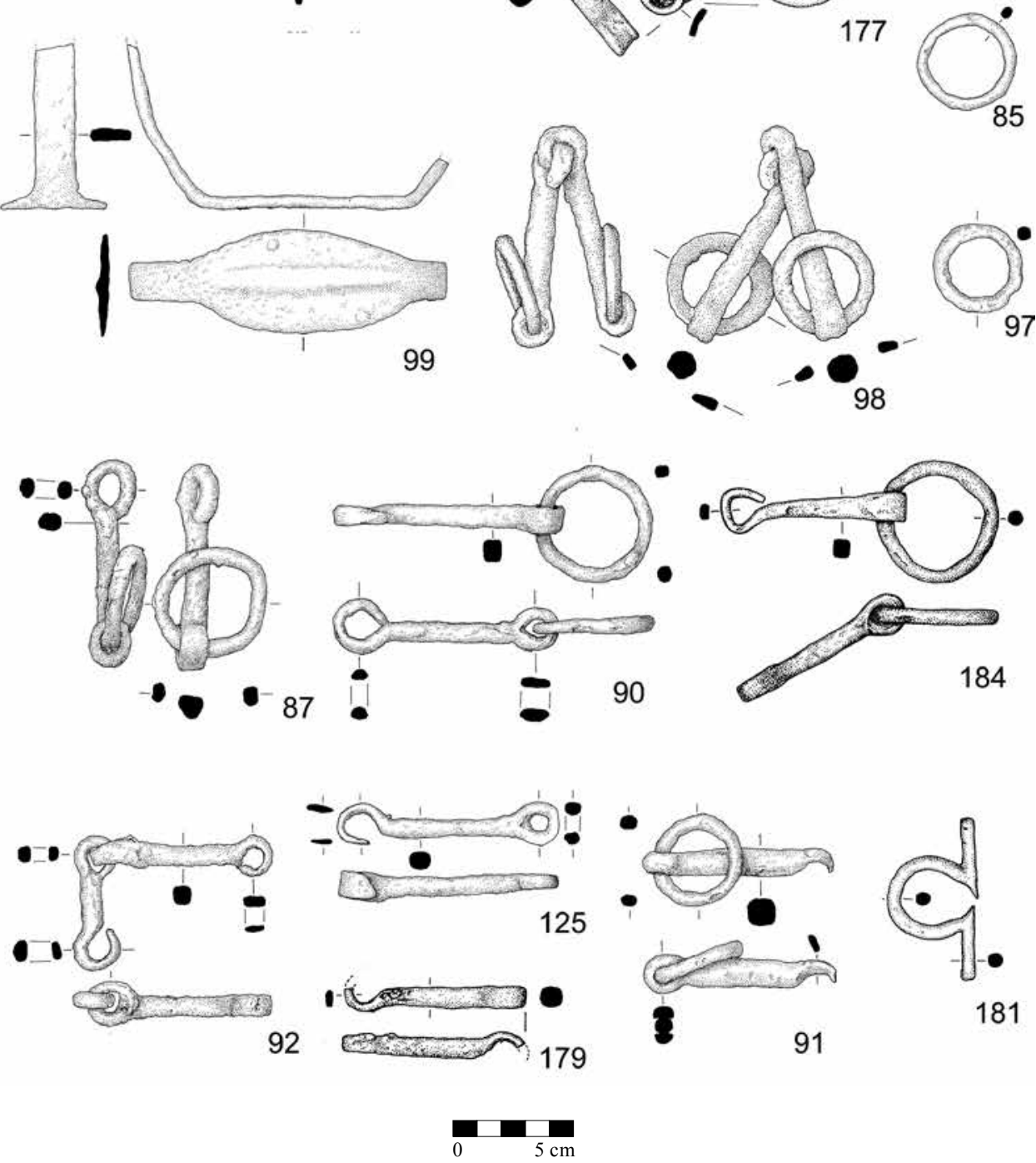

Obr. 14. Hrad Božanov. Třmeny, udidla a jejich součásti. Číslování odpovídá označení kovových artefaktů v textu. Abb. 14. Burg Božanov. Bügel, Zaumzeug und seine Bestandteile. Die Nummerierung entspricht der Kennzeichnung der Metallartefakte im Text. 

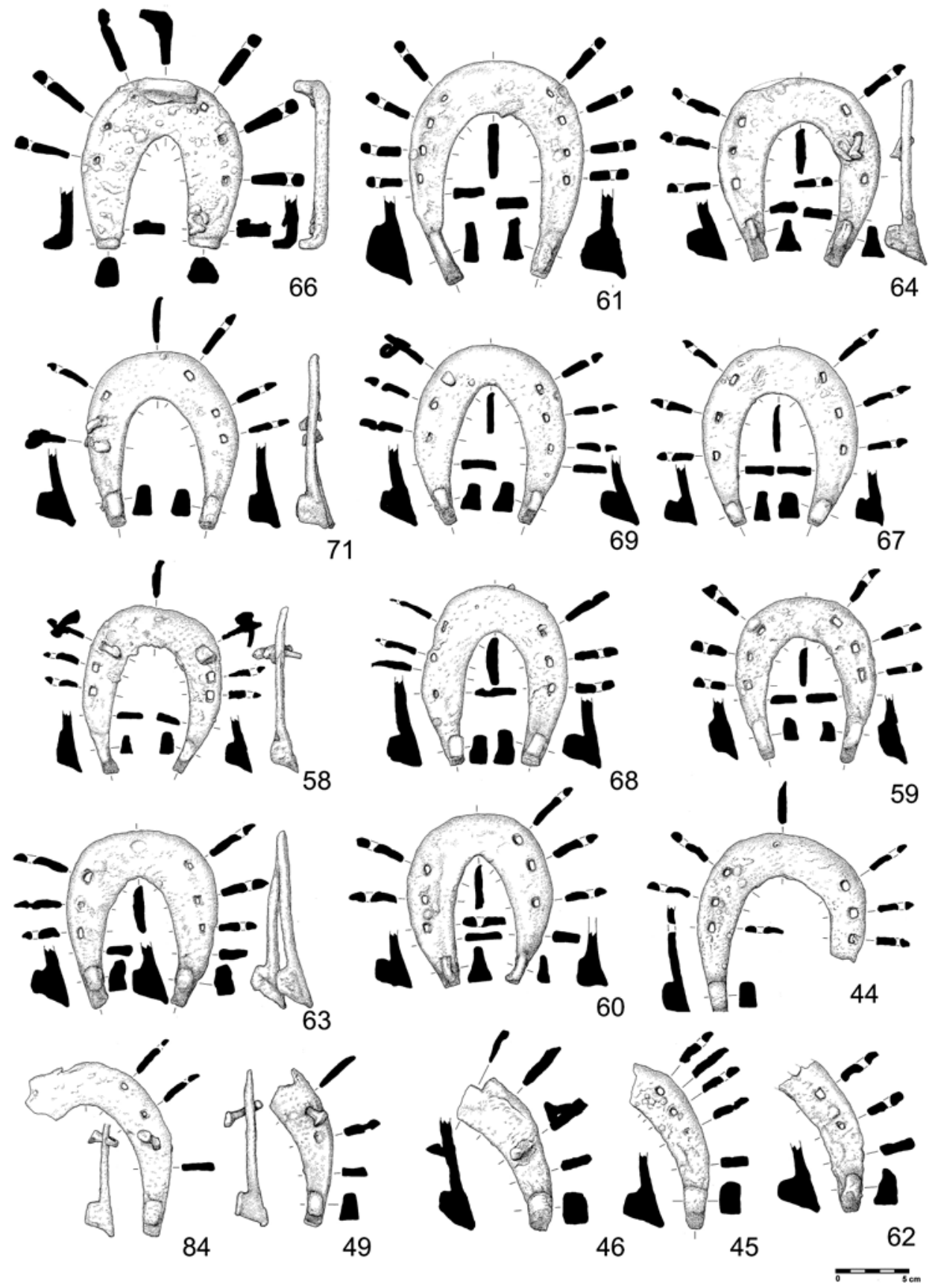

Obr. 15. Hrad Božanov. Podkovy. Číslování odpovídá označení kovových artefaktů v textu.

Abb. 15. Burg Božanov. Hufeisen. Die Nummerierung entspricht der Kennzeichnung der Metallartefakte im Text. 

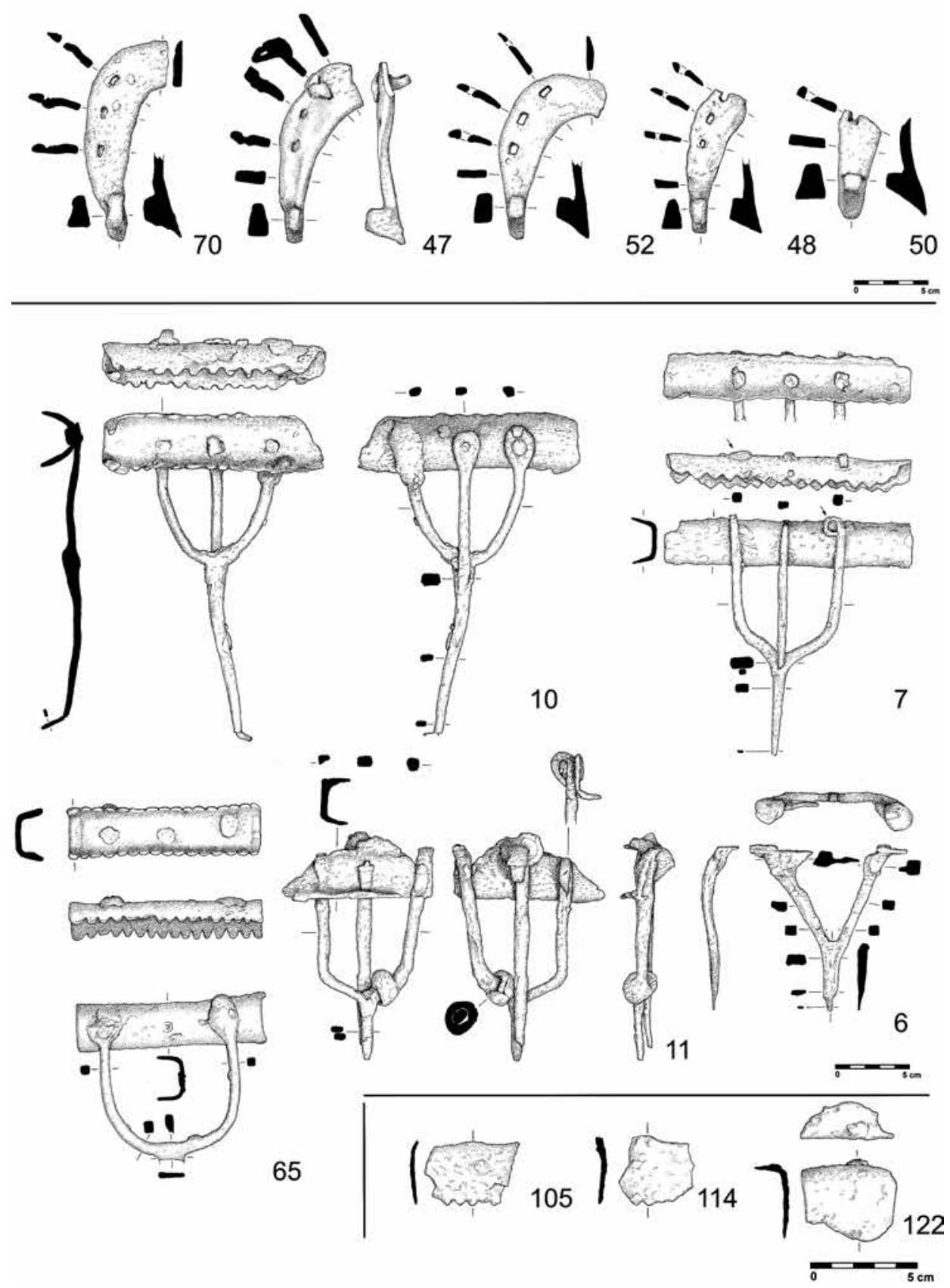

Obr. 16. Hrad Božanov. Podkovy, hřebla. Číslování odpovídá označení kovových artefaktů v textu.

Abb. 16. Burg Božanov. Hufeisen, Striegel. Die Nummerierung entspricht der Kennzeichnung der Metallartefakte im Text. 
ostruha se upínala na podpatek boty. Krček s hvězdicí výrazně poškozenou korozí je plynule prohnutý směrem dolů. Ostruha dokládá raně novověké a mladší aktivity v okolí hradu.

V souboru jsou prŕítomny i dva třmeny (obr. 13). Fragment závěsu (B 51) se podobá exemplářům z opevněných sídel Bolkov, Semonice nebo Rychleb a typu IV varianty D nebo F podle třídění W. Swietosławského, které spadají do druhé poloviny 13. až počátku 15 . století (Świętosławski 1990, 51-52, 109-113; Hejna 1962, 457, obr. 1:2-3, 458, obr. 2:1-2; Kouřil-PrixWihoda 2000, 319, obr. 221:1; Huml 1967, tab. IX:9, X:2). Druhý zlomek (B 99) představuje stupadlo a části ramen symetrického třmene. Do oválu ve středové části rozššřené stupadlo třmene zesiluje na spodní straně žebro. Takto formované stupadlo vyčlenil R. Krajíc jako tvar 2 a W. Świętosławski jako typ IV s variantou F (Krajíc 2003, 115, obr. 101). Zlomek mohl být součástí třmene se závěsem tvarovaným stejně jako u zlomku B 51 (Świętosławski 1990, 111).

K udidlům nebo jejich součástím, jako jsou postranní kruhy nebo postranice, náleží exempláře třinácti jedinců (B 85, 87, 90, 91, 92, 97, 98, 101, 184, 125, 177, 179, 181; obr. 13). Všechny tyčinky udítek jsou plné a většinou hraněné. Postranní kruhy mají většinou průřrez kruhový nebo výjimečně hraněný.

Zastoupené formy udidel z Božanova lze zařadit ke Krajícově typu 1 a typu 3. Krajícův typ 1 se objevil v Sezimově Ústí ve druhé polovině 13. století. Stíhlové udidlo Krajícova typu 3 časově spadá v Sezimově Ústí do první poloviny 14. století (Krajíc 2003, 110-111, obr. 98-99). Z hradu ve Veselí nad Moravou jsou také výrazně zastoupena stíhlová udidla a jedním exemplářem postranice tvarově shodná s božanovským nálezem B 181. Obdobná situace je i na hradě Přerovci, kde se v souboru kovových předmětů vedle sebe vyskytla udidla, která autoři obecně přiřadili do 13.-15. století (Kouřil-Prix-Wihoda 2000, 296). Veselský soubor je zařazen do průběhu druhé poloviny 13. století (Žákovský 2015, 234-235, obr. 13). Poměrně časté nálezy stíhlových udidel Krajícova typu 3 z hradních prostředí dokumentují nálezy z Bolkova (Hejna 1962, 457, obr. 1:8) a Červené Hory (Drnovský 2018, 157, obr. 206:2, 4), dále lze dohledat stíhlová udidla Krajícova typu 3 na lokalitách jako Hradišt'ko u Davle (Richter 1982, 166, obr. 112:1-2), z areálu hradu Rokštejna je doloženo i poloviční roubíkové udidlo (A 5390), které časově spadá do Ia horizontu před roky 1306-1307. Obdobné nálezy k postranici z Božanova (B 181) se objevují od druhé poloviny 13. století jako součást roubíkových udidel. Stíhlová udidla Krajícova typu 3 nastupují také ve druhé polovině 13. století (Žákovský 2015, 235; Krajíc 2003, 109-114).

Z dalších nálezů lze uvést i obsáhlý soubor sedmi hřebel a jejich částí (B 6, 7, 10, 11, 65, $105,114,122 ;$ obr. 16). Nálezy patří k několika různým formám podle tvaru rukojetí, samotných hřebenů i způsobů jejich spojení, které lze přiřadit typům C a B podle H. Vogta (1987). Ty se vyskytují od druhé poloviny 13. století a jejich výskyt pokračuje dále. Analogické tvary se objevily v situacích datovaných do druhé poloviny 13. století ve Veselí nad Moravou (Žákovský 2015, 236) či v Hradišt'ku u Davle (Richter 1982, 166, obr. 112:6).

Ačkoliv podkovy nepatří mezi chronologicky citlivé nálezy, vykazuje božanovský soubor 22 podkov (obr. 18, 16) tvarovou homogenitu (vyjma podkovy B $66 \mathrm{~s}$ hmatcem, kterou spojujeme s mladšími aktivitami v blízkosti lokality). Ostatních 21 podkov náleží ve formování ozubu podle R. Krajíce k tvarům 5d, 6b, 6d, poprŕípadě typům V/2 a VI/2-3 dle Kaźmierczykova třídění $(1978,156-157)$. Soubory podkov vhodné pro komparaci s božanovským souborem jak kvalitativně, tak kvantitativně pochází z Bolkova, Bradla u Hostinného, Cvilínku, Hradišt’ka u Davle, Rokštejna, Semonic, Sezimova Ústí a Veselí nad Moravou a ve všech př́padech se jedná o časový horizont průběhu druhé poloviny 13. století až počátku 14. století (Hejna 1962, 459, obr. 3:1; 1974, obr. 13:14-16, 395, obr. 14:9; Hrubý a kol. 2012, 393, 395, obr. 91; Richter 1982, 166-167, obr. 113:2-3; Huml 1967, 15, tab. IV:3, 5; Krajíc 2003, 104-105; Žákovský 2015, 235-236, 14:a-e). 


\subsubsection{Militaria}

Nejpočetnějšími z militarií se staly hroty šípů nebo střel, které reprezentují svou přítomností nejen použití luku, ale zároveň i kuše (obr. 17). ${ }^{15}$ Celkem se do zpracovávaného souboru dostalo 38 exemplářů. Analýza morfologie hrotů je založena na základních formálních vlastnostech hrotu a kódování jeho jednotlivých částí. Hroty se objevily v základní formě s tulejí (A) i s trnem (B). V případě aplikace typologie (Mazáčková 2012) na tyto hroty je nejobvyklejším tvarem varianta A-II-1-a-2 v počtu třinácti kusů a jeho mírně pozměněná varianta A-II-1-a-3 s rovnou tulejí s pěti exempláři. Dalším častým tvarem je forma A-III-1-a-2 zastoupená v souboru v počtu devět kusů. V souboru se objevují především hroty střel, které převažují nad hroty šípů s indexem poměru délky a váhy podle T. Durdíka (1972-1973), který stanovil hranici mezi oběma druhy na hodnotě 3 .

Hroty střel opatřené tulejí jsou především rombického průřezu, kde se největší rozšíření nachází blíže hrotu střely, čímž se zvyšuje průraznost projektilu při nárazu v závislosti na dopadové energii (forma: A-II-1-a-2; forma: A-II-1-a-3). Za povšimnutí stojí mediány délkováhového indexu u forem A-II-1-a-2 a A-II-1-a-3 zjištěné při porovnání kusů z lokalit Božanov a Rokštejn, kdy se forma A-II-1-a-3 s rovnou tulejí projevuje jako masivnější hrot v závislosti na větším vnitřním průměru tuleje pro nasazení dřevěného střeliště a forma s rozšířenou tulejí jako menší, i když řádově se jedná o rozdíly $\mathrm{v}$ milimetrech. Tomu odpovídají i mediány naměřených vnitřních průměrů tulejí u obou forem na Božanově i Rokštejně. U božanovské formy A-II-1-a-2 dosahuje medián vnitřního průměru tuleje 11,82, na Rokštejně jen 10,89, u druhé formy A-II-1-a-3 se jedná u božanovských kusů o 10,02, rokštejnské mají 10. Obě formy poukazují na vlastnosti kuše i celkový charakter střel s těmito nasazenými hroty, které se udržely po poměrně dlouhý časový úsek vrcholného až pozdního středověku.

Druhá nejpočetnější skupina je zastoupena hroty s největším rozšířením v polovině délky těla hrotu (skupina A-III), která je přítomna jen jednou tvarovou variantou A-III-1-a-2. Jeden hrot této skupiny byl nalezen ve fragmentárním stavu a nebylo možné určit další charakter hrotu. Doklady lukostřelby představují subtilní hroty s trnem opět rombického průřezu s největším rozšířením $\mathrm{v}$ horní třetině nebo polovině délky těla, které se dále zužuje směrem $\mathrm{k}$ trnu. Mezi lukostřelecké hroty s indexem vyšším než hranice 3 patří i hrot opatřený tulejí s krátkým tělem a výrazně se rozšiřující tulejí typu A-II-1-a-2. Prostorová distribuce hrotů střel a šípů v areálu hradu, ale zároveň v jeho okolí ve vzdálenosti mezi $70-100 \mathrm{~m} \mathrm{z}$ opevnění hradu představuje palebný prostor obránců z různých druhů střelných zbraní luků (hrot B 195) i kuší (B 192-194, 199, 200). Výskyt hrotů šípů a střel je kvalitně doložen se zaměřením z okolí hradu Sion nebo Rokštejn (Koscelník-Kypta-Savková 2013, 580, obr. 3; Mazáčková 2011, 78, obr. 13-14; 2012, 54, obr. 3-4).

Analogické tvary hrotů střel těchto dvou forem pocházejí z hradu Rokštejna (graf 4:3, 4), kde spadají až do závěrečného provozního a zánikového horizontu s následnými destrukcemi (IIIa, IIIb a IV), tedy do druhé poloviny 15 . století se zánikem spojeným s vojenskou akcí v druhé polovině roku 1467 (Mazáčková 2017, 758).

Pro srovnání s Božanovem je důležitý další soubor z hradu Sion, a to z výzkumu E. Jánské a pozdější terénní prospekce provedené v okolí hradu roku 2012 a publikované 2013. Z hradu a jeho okolí pochází 124 hrotů střel a šípů (graf 4:5, 6). Z areálu hradu Sion jde celkem o 34 hrotů formy A-II s největším rozšířením $v$ horní třetině délky těla, čtrnáct $\mathrm{z}$ nich lze zařadit $\mathrm{k}$ formě A-II-1-a-2. Druhou skupinu tvoří v počtu 22 hrotů formy A-III s největším rozšiřrením v polovině délky těla, z nichž sedm kusů náleží skupině A-III-1-a-2. Z povrchového průzkumu okolí hradu s obléhacími pozicemi pochází 55 hrotů střel nebo šípů, z toho náleží formě A-II-1-a-2 celkem devět kusů. Všechny patří střelám. V souboru však převažuje varianta A-II-1-a-3 s rovnou tulejí, celkem 21 kusů, které poukazují opět na používání kuše. Výjimkou může být jeden neprůkazný fragment IN 217. V samotném areálu hradu se tato tvarová varianta objevila jen ve dvou kusech

15 Typologie a terminologie dle J. Mazáčkové (2013, 304-314). 

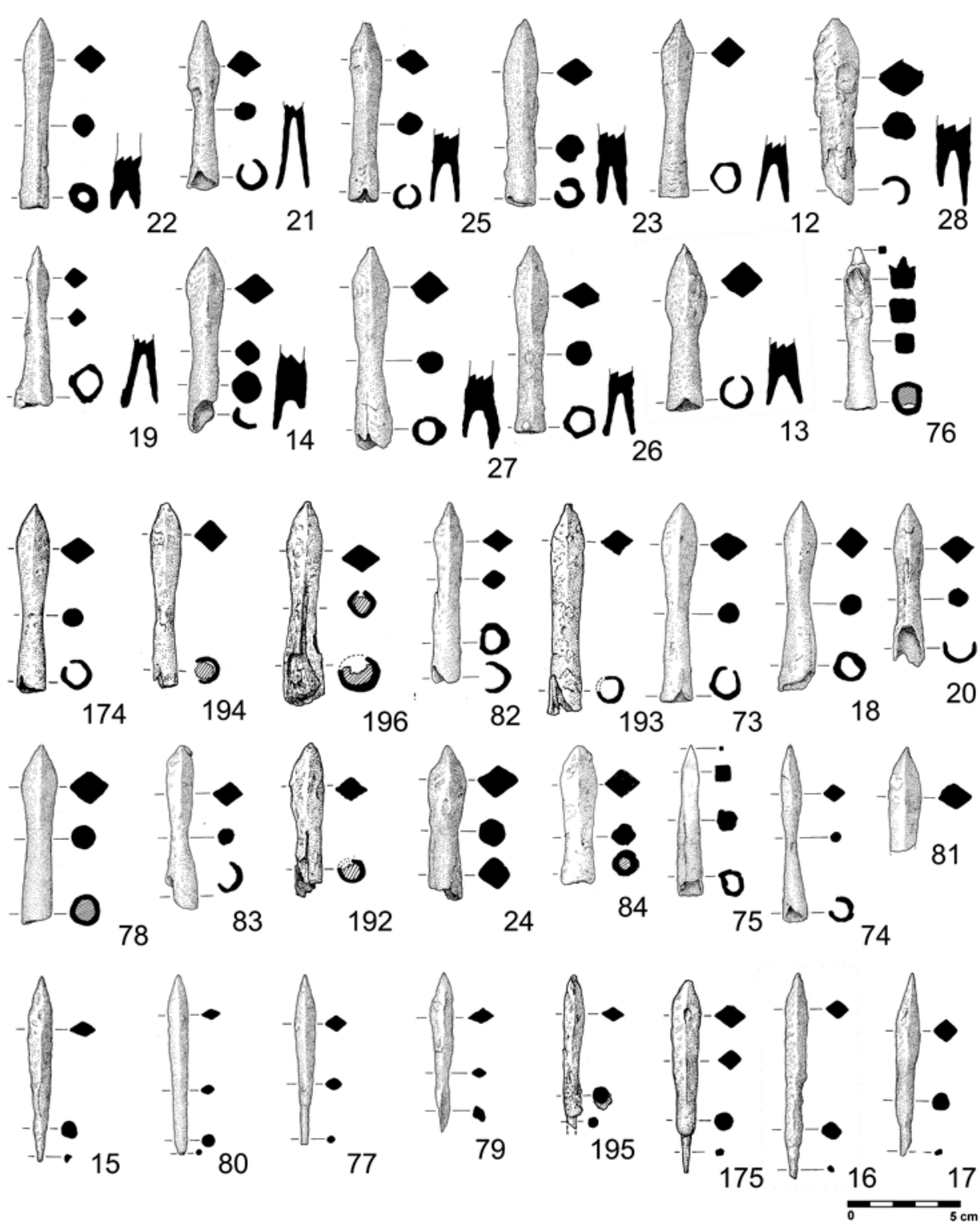

Obr. 17. Hrad Božanov. Hroty šípů. Číslování odpovídá označení kovových artefaktů v textu.

Abb. 17. Burg Božanov. Pfeilspitzen. Die Nummerierung entspricht der Kennzeichnung der Metallartefakte im Text.

(Jánská 1965, 42-45; Mazáčková 2013a, 38-41, 304; Koscelník-Kypta-Savková 2013, 586, obr. 7:IN 2017).

Při porovnání zmíněných hradních souborů kvalitativně přispívají hlavně hrady Rokštejn a Sion, kde se pro průběh 15. století objevují dosti významně obě formy A-II a A-III s variantami. V sionském i božanovském souboru prozatím převažují hroty formy A-II nad A-III, která dominuje v zánikovém horizontu Rokštejna. Lze konstatovat, že kuše, ze kterých se vystřelovaly střely opatřené hroty A-II-1-a-2, jsou standardem od konce 13. století do průběhu 15. století. 

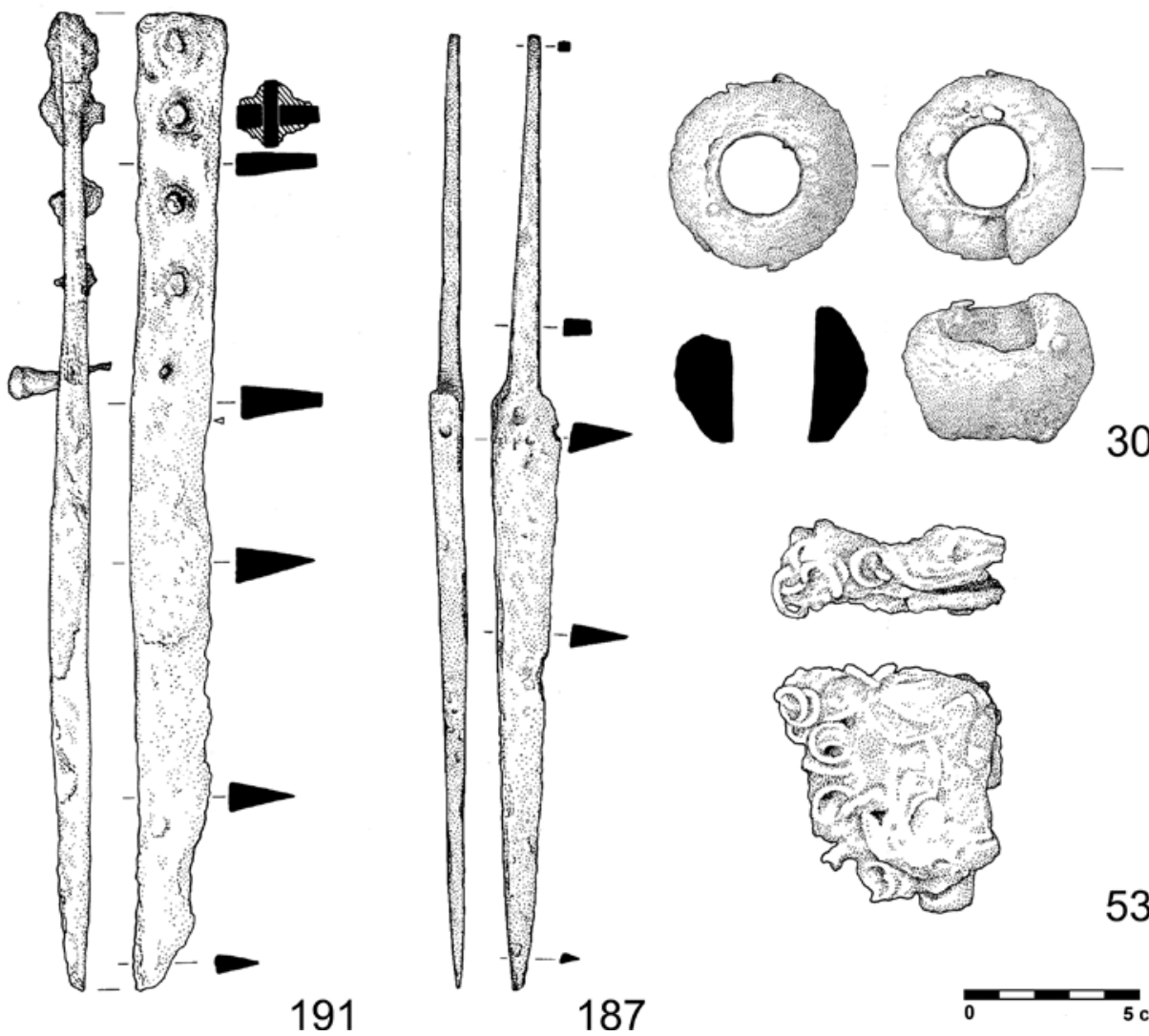

53

Obr. 18. Hrad Božanov. Tesák, dýka, palcát, kroužková zbroj. Číslování odpovídá označení kovových artefaktů v textu. Abb. 18. Burg Božanov. Jagdmesser, Dolch, Streitaxt, Ringwaffe. Die Nummerierung entspricht der Kennzeichnung der Metallartefakte im Text.

Rozhodujícím datačním faktorem se jeví hmotnost hrotů střel, i když tvarové vlastnosti hrotů přetrvávají do mladších období středověku, tedy průběhu 14. a dominantně až 15 . století. Božanovské hroty (především střel) nepřesahují hmotnost $50 \mathrm{~g}$, stejně jako hroty z Vízmburku. Medián délkováhového indexu šesti božanovských hrotů $\mathrm{s}$ hmotností nad $40 \mathrm{~g}$ je 1,87 a vyskytuje se u čtyř forem hrotů, u nichž převažují tvary A-II-1-a-3. U sionských hrotů získaných prospekcí z předpolí hradu a obléhacích stanovišt' překračuje u 39 z nich hmotnost $40 \mathrm{~g}$ a dosažené maximum je $78 \mathrm{~g}$. Rokštejnské střely dosahují maxima na $64 \mathrm{~g}$. Jedním z ideálních poměrů délky a váhy pro masivní hrot střely je $8: 5$ s délkováhovým indexem 1,6 (64:40, $80: 50,96: 60)$. Typickým průvodcem nasazení těžších forem bojových kuší jsou hroty stř̌el s hmotností nad $40 \mathrm{~g}$ a s délkováhovým indexem 1,3-2 dokládající výrazně bojové akce (Rokštejn a Sion). Ve formě hrotů variant A-II-1-a-2 a A-II-1-a-3 jsou zastoupeny pouze střely, skupina A-III-1-a-2 má zastoupené i formy hrotů šípů pro střelbu z luku. Medián délkováhového indexu dosahuje hodnoty 2,47 , a proto na základě uměle vytvořené hranice lze konstatovat, že v souboru převažují prozatím střely nad hroty šípů. Při přepočtu mediánu jen pro hroty střel se jedná o lehčí formy s hodnotou 2,25. Pod hranici 2 délkováhového indexu se dostaly jen hroty forem A-II-1-a-3, jedná se o masivní kusy $(\mathrm{B} 27,28,78)$. Exemplář $\mathrm{B} 28$ je mírně poškozený v tuleji. Forma A-II-1-a-2 je zastoupena jen dvěma hroty na hodnotě délkováhového indexu 2 (B 84, 200). 
Artefakt určený jako hlavice palcátu/bulavy (B 30; obr. 18) má kulovitý mírně dvoukónický tvar se středovým otvorem. Železná hlavice váží $171 \mathrm{~g}$ a největší naměřený průměr dosahuje $48 \mathrm{~mm}$. Vnitřní průměr tuleje pro násadu je $21,14 \mathrm{~mm}$. Kovový předmět svým celkovým charakterem připomíná palcát z mad’arského území Kovácsova typu V. bez výčnělků, který se v Uhrách objevil již v průběhu 12. až 13. století (Kovács 1971, 178-180, obr. 6:5). Z českého prostředí může posloužit pro formální určení artefaktu bronzová kulovitá hlavice z Podlažic s největším vnějším průměrem $47 \mathrm{~mm}$ a vnitřním průměrem $24 \times 17 \mathrm{~mm}$ (Musil 2017, 6). Téměř identická analogie železné hlavice palcátu pak pochází z náhodného detektorového průzkumu na katastrálním území obce Neratov (okr. Pardubice). ${ }^{16}$ Ze srbského prostředí jsou známy dvě železné elipsoidní hlavice palcátů s náznakem rýh jako per z neznámé lokality, které jsou deponovány v bělehradském vojenském muzeu. Průměr hlavic je výrazně větší než u božanovského kusu. První (inv. č. 13634) má v průměru 110 mm, druhá je menší (inv. č. 16366). Její průměr dosahuje 75 mm (Peković 2006, 113-114). Další analogií zařazenou mezi palcáty je hlavice z ruské Dorogobuže, která nese na kulovitém těle nízké ostny. Ty se ve velice setřelém stavu objevily na mad’arském exempláři. Průměr otvoru tuleje dosahuje až $32 \mathrm{~mm}$ a průměr hlavice $40 \mathrm{~mm}$ (Liwoch 2006, 70-71, obr. 2:4-5). A. N. Kirpičnikov uvádí z prostoru Ruska šest základních tvarů hlavic palcátů, kulatá nebo dvoukónická hlavice mezi nimi nefiguruje (Kirpičnikov 1966, 49, obr. 10). I když se hlavice palcátů spojují se stepním prostředím a původem v centrální Asii 9. až 10. století, lze je spíše identifikovat na území původní Byzantské ř́iše (9.-15. století), ale i Chazarské ŕíše nebo v místech ovládaných Seldžuky v průběhu 10. až 13. století, např́iklad v Íránu (Ruttkay 1976, 315; Świętosławski 1996, 38-39).

Mezi poboční chladné zbraně náleží dýka (B 187; obr. 18), jejíž hmotnost dosahuje $80 \mathrm{~g}$. Předmět má jednobřitou čepel opatřenou masivním hřbetem a oboustranné odsazení čepele $\mathrm{k}$ trnu rukojeti. Hrot čepele s trnem jsou v jedné ose. Zachovaná délka odpovídá $274 \mathrm{~mm}$. Délka samotné čepele dosahuje $170 \mathrm{~mm}$ a délka oboustranně odsazeného trnu rukojeti je $104 \mathrm{~mm}$. Výška čepele má $21 \mathrm{~mm}$ a zužuje se směrem k hrotu. Šířka hřbetu čepele je $9,4 \mathrm{~mm}$, což z artefaktu činí jednobřitou dýku s masivním hřbetem proti deformaci při průniku. Trn rukojeti se zužuje a v délce mění profil od odsazení od čepele, kde je profilován do obdélníku, k oválnému profilu na konci trnu. Zbraň se řadí k dýkám, jež charakterizují čepele s jedním ostřím a hrotem situovaným v ose zbraně. Jejich široké časové zařazení do 13. až 16. století mohou omezit jen vyhodnocené kvalitativní stratigrafické situace nebo dochované organické rukojeti, jako v př́ípadě dýk s ledvinovitými vývalky (Žákovský 2011, 146; Dragoun 1983; Vích-Žákovský 2016, 290). Obdobě formované čepele dýk pocházejí z českého prostředí z Hradišt'ka u Davle, kde jsou dlouhé kusy s masivním hřbetem a odsazením zařazeny mezi nože s délkou $270 \mathrm{~mm}$ s trnem (Richter 1982, 156-157, obr. 99:6), hradu Bolkova (Hejna 1962, 463, obr. 5:7), hradu Orlíka u Brandýsa nad Orlicí (Vích-Žákovský 2016, 287, obr. 8:63; 290-291) a z hradu Templštejna (Žákovský 2011, 133, obr. 4:2-3, 143, tab. VI:2-3). O dalších analogiích lze eventuálně uvažovat ze zaniklého Bystřece, kde tyto jsou přiřazeny k nožům (Belcredi 2006, 364, tab. XLII:9, 365, tab. XLIII:18), a Červené Hory (Drnovský 2018, 166, obr. 212:1). Obecně lze konstatovat jejich časové zařazení do období 13. až 15. století (Žákovský 2011, 146).

Druhou poboční chladnou zbraní je nožový tesák se zachovaným záštitným trnem (B 191; obr. 18). Hmotnost artefaktu je $179 \mathrm{~g}$. Celková délka dosahuje $280 \mathrm{~mm}$, z toho na čepel připadá $165 \mathrm{~mm}$. Výška čepele je $22,6 \mathrm{~mm}$ a šířka hřbetu je $11,7 \mathrm{~mm}$. Na jazykovité rukojeti jsou zachovány čtyři nýty $\mathrm{z}$ upevnění střenky. Záštitný trn má kapkovitý tvar s maximálním průměrem $9,7 \mathrm{~mm}$ a výškou $16,2 \mathrm{~mm}$ a standardní umístění na přechodu čepele a rukojeti. Rukojet' je symetrická, zakončená mírně zaobleným týlem a má oboustranné mírné boční konkávní prohnutí v části nad trnem a z obou stran středovou rýhu pro nýty. Přechod čepele v rukojet' je zvýrazněný pouze zúžením šíŕky hřbetu čepele ve hřbet rukojeti. Jinak je šířka čepele a šiřka rukojeti v místě přechodu stejná, ovlivněná korozí. Čepel opatřená výrazným hřbetním zesílením má nožovitou část určenou spíše k sekání a řezání, nikoliv k bodání jako předchozí dýka. Čepel

16 Nepublikováno, uloženo ve Východočeském muzeu v Pardubicích, př. č. 591/2017. 
si uchovává při největší délce konstantní šǐřku a k zúžení dochází $40 \mathrm{~mm}$ od hrotu samotného. Tvarově podobné tesáky pochází z lokalit Brno-Staré Brno, Smilovo Hradisko a Veselí nad Moravou. Všechny tři jsou shodně zařazeny do závěru 13. století a mají rovný týl rukojeti. Tesák z Veselí má dochovaný i záštitný trn formovaný do prohnuté kruhové výseče (Žákovský 2011a, 122, obr. 16; 2014, 179, kat. č. 260). Další analogický tvar je deponován v Muzeum Regionalne w Jaworze ve Slezsku a datován do druhé poloviny 14. až 15. století (Marek 2008, 29, 192, obr. 19 b, c, d). M. Lewandowski řadí tento tvar B2 do delšího časového úseku od průběhu 13. až do 15. století (Lewandowski 1986, 108, 118). Mladší tvary reprezentované nálezy z Konůvek nebo Roštína jsou datované do 15 . až první poloviny 16. století. Roštínský tesák má rukojet' mírně vyhnutou z osy zbraně (Žákovský 2014, 50, kat. č. 68). Rozměry se podobá božanovskému kusu tesák z Konůvek (Měchurová 1997, tab. LX:5).

$\mathrm{Z}$ ochranné zbroje je doložen fragment kroužkové zbroje. Jedná se o zkorodovaný útržek několikrát přehnuté kroužkové zbroje s kovovým plátkem (B 53; obr. 18), u kterého bylo s obtížemi proveditelné bližšśi určení struktury a velikosti jednotlivých kroužků. Vnější průměr kroužků se pohybuje mezi 8 až $9 \mathrm{~mm}$. Průměr drátu, z něhož byl kroužek vyroben, je kolem 1,5-1,6 mm. Způsob spojení kroužků není kvůli poškození korozí pozorovatelný, lze počítat s oběma technologiemi, a to se svařováním a nýtováním. Brnění má stejnou hustotu pletiva jako fragmenty kroužkové zbroje z polské lokality Plemiety nebo slovenského hradu Sklabina (Šimcík-Pupala 2005, 94; Nadolski-Grabarczykowa 1985, 85-87). Fragmenty brnění nebo možného závěsu přilby poukazují na druhovou skladbu ochranné zbroje na božanovském hradě.

\subsubsection{Součásti oděvu a predměty osobni potřeby}

$\mathrm{K}$ nejčastěji nalézaným součástem středověkého oděvu bezesporu patří přezky různých velikostí a tvarování (obr. 19). Nejinak tomu je i v př́ípadě božanovského souboru. Tento druh výrobku našel uplatnění i v jiných složkách hmotné kultury, tudíž je zařazení konkrétních exemplářù závislé na celkové velikosti, tvaru a provedení daného výrobku. Vzhledem k nalézanému množství se přezkám věnovala řada domácích (Ruttkay 1989; Procházka 1990, 99-109; Zůbek 2002; Krajíc 2003, 193-194) i cizích autorů (Fingerlin 1971; Heindel 1990; Wachowski 1994; Egan-Pritchard 2002). Pro naši kolekci použijeme tř́́dění, které navrhl S. Krabath (2001). Božanovské exempláře jsou jednodílné a vyrobené ze železa vykováním. Odlévané přezky z barevných kovů se nevyskytují. První přezka (B 36) má polooválný tvar, její obloukovité rameno je uprostřed rozšířeno do plošky, na kterou dosedá dochovaný trn (typ K4). Př́i výšce $67 \mathrm{~mm}$ se jedná o přezku, u níž můžeme alternativně počítat i s jinou než oděvní součástí. Analogické nálezy pochází např́íklad z Bolkova (Hejna 1962, 460, obr. 3:4), Bystřece (Belcredi 2006, 362, tab. XLII:2), Hradce Králové - Velkého náměstí (Mazáčová 2012, 92, obr. 80), Jihlavy (Mazáčová 2012, 92, obr. 81) či Orlíka u Brandýsa nad Orlicí (Vích-Žákovský 2016, 319, obr. 39:e). Další přezka (B 32) má rovněž polooválný tvar, pravidelný oblouk však zůstává po celé délce stejně široký. Z trnu se dochovalo pouze zavinutí okolo rovnější části těla (typ E4). Výška přezky činí $45 \mathrm{~mm}, \mathrm{z}$ obdobných nálezů lze uvést přezky z Červené Hory (Drnovský 2018, 167-168, obr. 206:10), Bolkova (Hejna 1962, 460, obr. 3:4), Bradla (Hejna 1974, 396, obr. 13:13), Hradišt'ka u Davle (Richter 1982, 160, obr. 105:3), obléhacího tábora u hradu Lichnice (Frolík-Musil 2013, 160, obr. 28:2), Rábí (Durdík 1989, 281, obr. 4:4), Rýzmburku (Drnovský 2015, 381, obr. 3:7), Vízmburku (Macháňová 2013, 141, tab. 61:6, 12) nebo Vildštejna (Durdík-Frolík 1993, 58, obr. 20:6). Následující čtyři přezky lze zařadit k typu C10, což znamená, že jedno rameno je svislé a rovné, zbývající část je tvarována do pravidelného oblouku. Průřez a šiřka přezky se výrazně nemění a celkově připomíná tvar písmene D. První dvě přezky (B 34, B 43) se vyznačují většími rozměry (výška 87 a $97 \mathrm{~mm}$ ), takže bychom u nich spíše měli předpokládat užití v součástech koňského postroje, např́iklad v uchycení sedla (srov. Clark 1995, 55-61). Zbylé dvě přezky (B 41, B 140) svými rozměry (výška 48 a $47 \mathrm{~mm}$ ) odpovídají obvyklým mírám. Tento tvar přezek představuje velmi rozšířený typ, se kterým se lze setkat na řadě lokalit. Za všechny zmiňme nálezy z Červené Hory (Drnovský 2018, 167-168, obr. 206:10), Hradišt'ka u Davle (Richter 1982, 160, obr. 105:11, 13), Prahy-Vokovic (Chmielowiec-Kašpar-Zdaniewicz 2013, 284-285, obr. 10:e), 

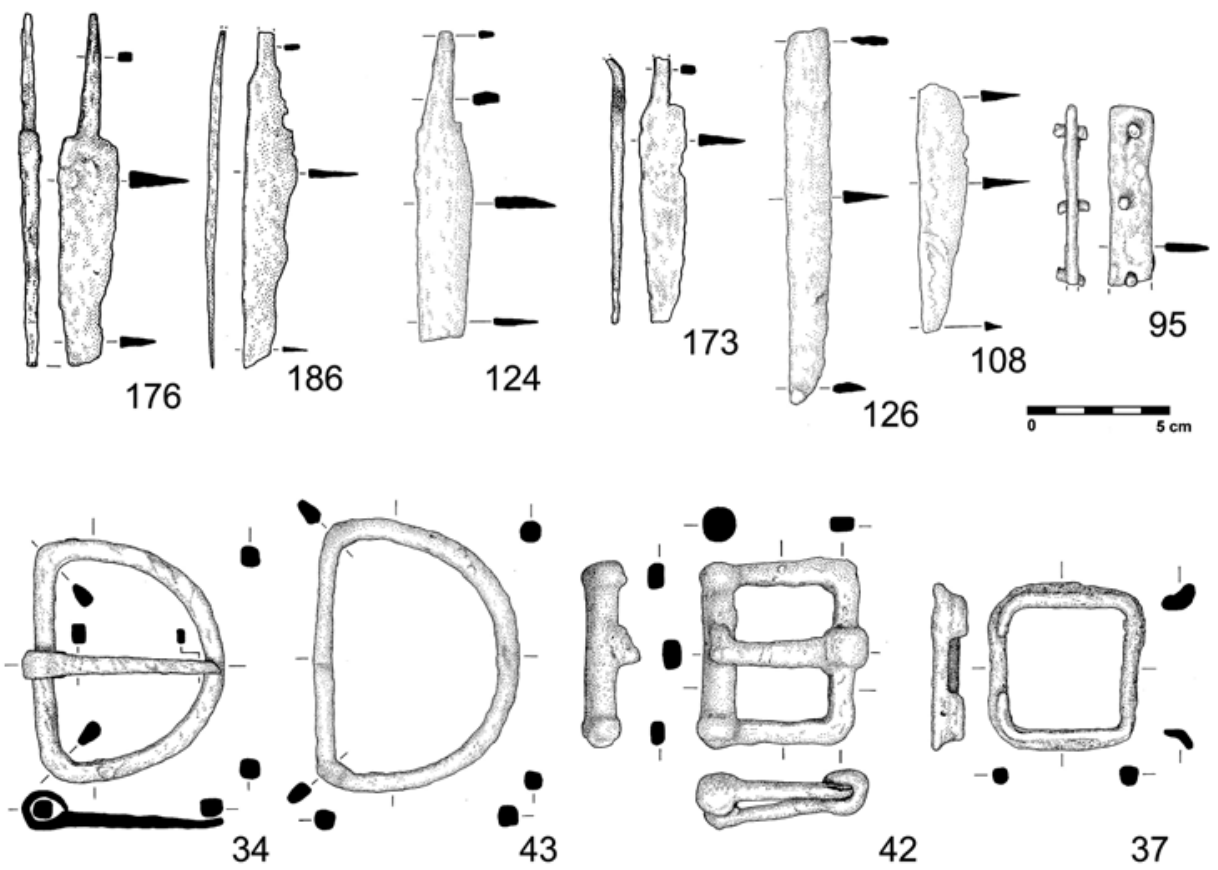

34

43

42

37
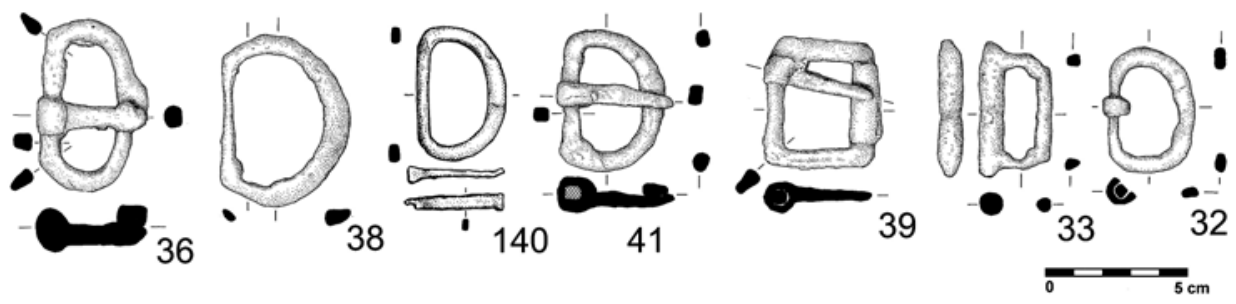

Obr. 19. Hrad Božanov. Nože, přezky. Číslování odpovídá označení kovových artefaktů v textu. Abb. 19. Burg Božanov. Messer, Schnallen. Die Nummerierung entspricht der Kennzeichnung der Metallartefakte im Text.

prostoru fortifikace v předpolí hradu Lanšperka (Vích 2010, 339, obr. 10:8), Rábí (Durdík 1989, 285, obr. 4:9), Vildštejna (Durdík-Frolík 1993, 58, obr. 20:1, 5) či Vízmburku (Macháňová 2013, 141, tab. 61:4, 12). I pro další přezku (B 38) je charakteristický tvar písmene $\mathrm{D}$, od předešlých se však liší obloukem, který se od svislé části postupně rozšiřuje (typ D10). Obdobné přezky byly nalezeny např́íklad na Červené Hoře (Drnovský 2018, 167-168, obr. 206:8), v Hradci Králové Velkém náměstí (Richter-Vokolek 1995, tab. 118:26, 32), Hradišt'ku u Davle (Richter 1982, 160, obr. 105:7), Křinci (Vích 2013, 316, obr. 19:5), Rábí (Durdík 1989, 282, obr. 4:9) nebo Týřově (Durdík 1976, tab. LI:4, 5).

Zbývající přezky jsou již obdélného formátu. Dvě přezky se vyznačují pravidelným rámečkem, který má tři strany obdélného průřezu, ale čtvrtá (protilehlá vůči úchytu trnu) je větší a navíc kruhového průřezu (typ M21). Funkční určení první přezky (B 42) není kvůli její robustnosti (výška $65 \mathrm{~mm}$ ) jednoznačné, a nutně se nemusí jednat o oděvní součást. Druhá přezka (B 39) je menších rozměrů (výška $47 \mathrm{~mm}$ ). Z analogií lze uvést např́íklad přezky z Křince (Vích 


\begin{tabular}{|c|c|c|c|}
\hline skupina & předmět & počet & celkem \\
\hline \multirow{6}{*}{ Stavební kování, součásti provozního vybavení } & hřebík & 47 & \multirow{6}{*}{52} \\
\hline & držadlo vědra & 1 & \\
\hline & klíč & 1 & \\
\hline & oko řetězu & 1 & \\
\hline & závlačka & 1 & \\
\hline & zámek & 1 & \\
\hline \multirow{6}{*}{ Řemeslnické nástroje a zemědělské nářadí } & dláto & 1 & \multirow{6}{*}{10} \\
\hline & kladivo & 1 & \\
\hline & motyka & 1 & \\
\hline & sekera & 1 & \\
\hline & srp & 4 & \\
\hline & nebozez & 2 & \\
\hline \multirow{6}{*}{ Výstroj jezdce a koně } & ostruha & 11 & \multirow{6}{*}{78} \\
\hline & třmen & 2 & \\
\hline & udidla a jejich součásti & 13 & \\
\hline & podkova & 22 & \\
\hline & podkovák & 22 & \\
\hline & hřeblo & 8 & \\
\hline \multirow{5}{*}{ Militaria } & palcát & 1 & \multirow{5}{*}{42} \\
\hline & zbroj kroužková & 1 & \\
\hline & dýka & 1 & \\
\hline & tesák & 1 & \\
\hline & hrot šípu & 38 & \\
\hline \multirow{5}{*}{ Součásti oděvu a předměty osobní potřeby } & brakteátové pouzdro & 1 & \multirow{5}{*}{23} \\
\hline & pražský groš & 1 & \\
\hline & nůž & 7 & \\
\hline & přezka & 13 & \\
\hline & nákončí opasku & 1 & \\
\hline Součet & & 205 & \\
\hline
\end{tabular}

Tab. 1. Hrad Božanov. Zastoupení jednotlivých kategorií kovových nálezů. Tab. 1. Burg Božanov. Vertretene Kategorien der Metallfunde.

2013, 316, obr. 19:6, 7), prostoru fortifikace v předpolí hradu Lanšperka (Vích 2016a, 331, obr. 6:5), Hradišt'ka u Davle (Richter 1982, 163, obr. 106:1, 3, 4, 7-9) či Sezimova Ústí (Krajíc 2003b, 136, tab. 146). Následující přezka (B 37) je rovněž obdélného formátu (typ C21), nese však dvě netypická konstrukční řešení. Ramena jsou příčně prohnutá, tudíž spodní strana přezky je širší než horní. Zároveň je v místech, kam dosedá hrot trnu, rameno rámečku sníženo. Bližší analogii známe z např́́klad z Telče (Mazáčová 2012, 89, obr. 38). Poslední popisovaná přezka (B 33) se vyznačuje trapézovitým tvarem, kdy se obě horizontální ramena rámečku sbíhají k sobě (typ M30). Obdobné přezky byly objeveny v Brandýse nad Orlicí (Vích 2014, 150, obr. 5:2), Bystřeci (Belcredi 2006, 362, tab. XLII:3), Sezimově Ústí (Krajíc 2003b, 136, tab. 146), Hradci Králové Velkém náměstí (Richter-Vokolek 1995, tab. 118:13) nebo Vildštejně (Durdík-Frolík 1993, 59, obr. 18:15). 
Většina přezek představuje spíše chronologicky méně výrazné výrobky a přesnější datovaní umožňují spíše ojedinělé kusy. Podobně tomu je u výše popsaných typů, jejichž výskyt S. Krabath (2001, 134-145) klade do širšího rámce 12.-15. století (typ C10, C21), př́ípadně 13.-14. století (typ D10) nebo obecně do 14. století (typ K4, E4, M21, M30). Uvedené analogie $\mathrm{k}$ božanovským nálezům pak nejsou s tímto zařazením $\mathrm{v}$ rozporu.

Posledním nálezem je prodloužené oboustranné nákončí (B 190; obr. 20). Předmět je složený ze dvou destiček vyrobených z barevného kovu, aversní a reversní. Mezi nimi je umístěna destička železná, která nákončí vyztužuje. Nákončí prodlužovalo a částečně kopírovalo tvar ukončení patrně koženého řemene opasku. Předmět váží 21 g. Celková délka mírně poškozeného nákončí je $78,3 \mathrm{~mm}$. Největší šířka dosahuje 23,7 mm. Destičky nákončí a původní organické kožené řemení jsou spojeny dvěma železnými nýty. Rozevření pro organickou část řemenu představuje mezeru o rozměru $3,32 \mathrm{~mm}$. Předmět je opatřen výzdobou, která představuje ve střední Evropě méně častý motiv draka. Drak na božanovském nákončí představuje univerzální motiv dvounohého kráčejícího bájného zvířete se složenými křídly, dlouhým labutím krkem a otevřenou tlamou. Dračí tlama je ztvárněna jako mírně rozevřené dlouhé úzké čelisti. Ocas je prodloužen vegetabilním motivem palmet $\mathrm{s}$ jednou vlnou. Poměrně neobvyklý nález má hned dvě analogie z českomoravského prostoru a jednu ze slovenského. Nákončí ze Semic u Nymburka o rozměrech $79 \times 20 \mathrm{~mm}$ je časově zařazeno do první poloviny 14 . století a má identickou konstrukci jako božanovský kus. Nákončí ze Starého Města je v celé délce stejně široké, o rozměrech $73 \times 6 \mathrm{~mm}$ a má zaoblené ukončení. I tento exemplář je řazen do první poloviny 14. století (Motyková 2004, 6, obr. 2; Mazáčová 2012, 95, kat. č. 114, 129:114). Obě nákončí nesou motiv dvounohého draka s rozevřenou tlamou a ocasem doplněným vegetabilními aplikacemi. Semický drak má jednu vlnu na ocasu. Drak ze Starého Města má dokonce čtyři vlny. Ze slovenského Pustého hradu pochází přezka s destičkou a nákončí, které má konstrukci i vyobrazení draka nejblíže božanovskému exempláři. Časové zařazení slovenského nákončí spadá na přelom 13. a 14. století. Drak má dvě vlny doplněné trojlistem nebo palmetou na ocase (Hanuliak 1993, 161-163; Ragač 2001, 442-443, obr. 1:8). Motiv draků se objevuje ve stylizované podobě například na rukojetích a záštitách středověkých dýk (Michalak 2018).

Postava draka je rovněž poměrně častým motivem knižní malby, kde je součástí pletenců v kapitálách písmen jako v Mater verborum, datovaném kolem roku 1240, na zobrazení zápasu lva s drakem (113r), Archanděl Michael zabíjí draka (141r), kapitála R (142r), kapitála Z (192v), kapitála (215v) nebo kapitála T (240v) či kapitála Z (241v) ${ }^{17}$ V Epištoláři Pražské diecéze datovaném k roku 1260 je zobrazen drak s vegetabilním motivem na ocase již na první iluminaci, kde se zakusuje do výzdoby kapitály F (1v). ${ }^{18}$ Obdobnou stylistiku má Jaroměřská bible francouzského původu z konce 13. století, napríklad kapitála R (13r) nebo zobrazení dvounohého draka s prodlouženýma ušima a vegetabilními aplikacemi na ocase $(15 \mathrm{v}),{ }^{19}$ či Františkánská bible ze 70.-80. let 13. století na vyobrazení iniciály L s evangelistou Lukášem (259r) nebo kapitály L se dvěma bojujícími draky, kteří mají formované hlavy jako božanovský drak z nákončí (85r), nebo pletenec draků v kapitále O (150v; Krása 1990, 43, obr. 16). ${ }^{20}$ Olomoucký misál CO 585 pochází z konce 13. století a opět u kapitály R nebo S se objevují dvounozí draci, kteří mají ocas s vegetabilními aplikacemi (Majer 2011, 565, 567, obr. c, 569, obr. e). Další vyobrazení draků lze nalézt ve Velislavově bibli datované k roku 1340. Na vyobrazení Apokalypsy a boje archanděla Michaela s drakem (153r, 163v, 164r) jsou dvounozí draci s několikanásobně stočeným ocasem. Zobrazení těla sedmihlavé saně (163r) je provedeno obdobně jako dračí. Detailně propracovaná hlava draka má zobrazené zuby a jazyk, krátké uši a silný kratší krk, nohy jsou šelmy s drápy

17 Enrich manuscriprotium Mater verborum, tzv. Glosa Salamonis. Dostupné z: http://v2.manuscriptorium.com/apps/main/index. php?request=request_document\&docId=set04071382, cit. 14. 2. 2019.

18 Erich manuscriptorium Epištolář pražské diecéze. Dostupné z: http://v2.manuscriptorium.com/apps/main/index.php?request=request_document\&docId=set04020669, cit. 14. 2. 2019.

19 Erich manuscriptorium Jaroměřská bible. Dostupné z: http://v2.manuscriptorium.com/apps/main/index.php?request=request_document\&docId=set031101set4125, cit. 14. 2. 2019.

20 Erich manuscriptorium Františkánská bible. Dostupné z: http://v2.manuscriptorium.com/apps/main/en/index.php?request=request_document\&docId=set031101set4134, cit. 14. 2. 2019. 


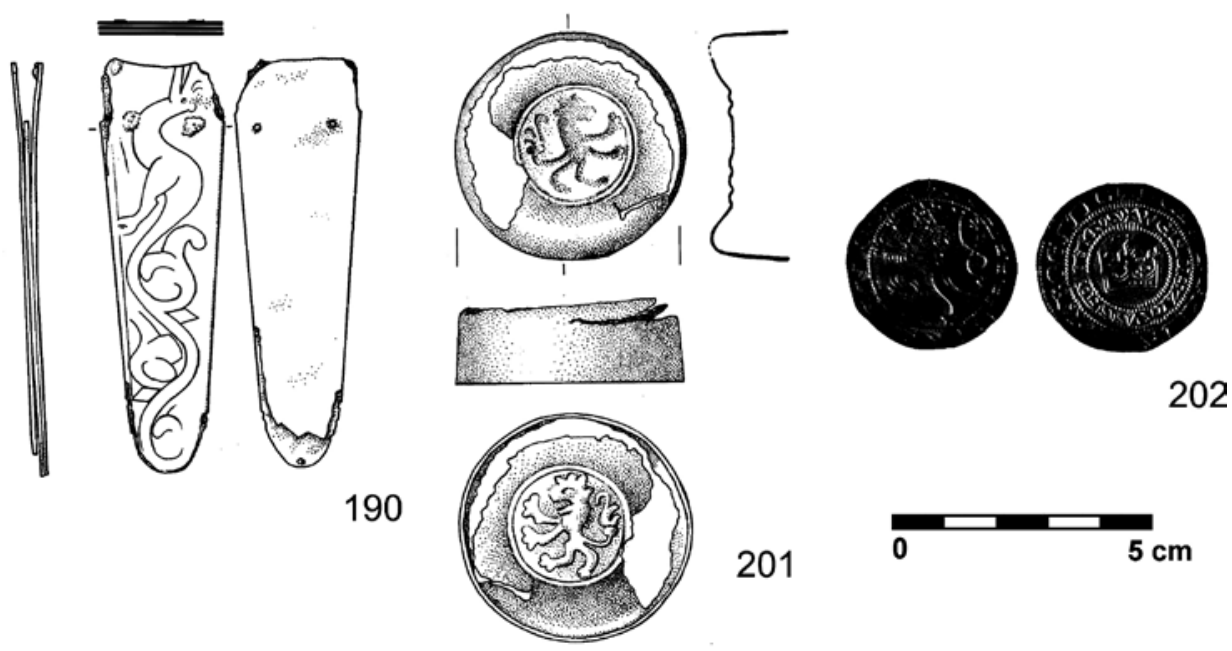

Obr. 20. Hrad Božanov. Nákončí opasku, brakteátové pouzdro, pražský groš. Číslování odpovídá označení kovových artefaktů v textu.

Abb. 20. Burg Božanov. Gürtelzunge, Brakteaten-Hülse, Prager Groschen. Die Nummerierung entspricht der Kennzeichnung der Metallartefakte im Text.

a opeřená křídla dravce. Mladší zobrazení draků jako v Liber Viaticus, datované kolem 1360, má dále propracované zobrazení dvounohého draka s vegetabilními aplikacemi většinou již jen na konci ocasu $(24 \mathrm{r}, 43 \mathrm{v}) .{ }^{21}$ Vegetabilní aplikace na dračím ocase božanovského nákončí odpovídají ikonografickým pramenům ze 13. století a vegetabilním motivům např́iklad Františkánské bible ze 70.-80. let 13. století včetně způsobu zobrazení draka (obr. 21).

\subsubsection{Monetární nálezy}

Částečně poškozený nález (B 201; obr. 20) - vyrobený z jednoho kusu tenkého plíšku s vyobrazením kráčejícího lva lze označit za součást tzv. brakteátové schránky. Předmět je poškozený v místě prohnutí hlubší misky. Průměr předmětu dosahuje $45 \mathrm{~mm}$ a jeho výška $15 \mathrm{~mm}$, jeho hmotnost je $12 \mathrm{~g}$. Artefakt je formálně shodný s mincovní schránkou z hradu Obřany (Nekuda 1990, 222-223; Hrubý a kol. 2006, 245-246, obr. 46:8). V obou př́ípadech se jedná o hlubší miskovitý plechový předmět z barevného kovu s poměrně vysokým okrajem. Ve středu vnitřní strany prohnuté misky je vyražen heraldický motiv. Negativ je z vnější strany předmětu. V případě božanovského i obřanského exempláře je motivem v kruhu umístěný vlevo hledící kráčející lev s korunou. $\mathrm{K}$ aplikovanému motivu u obou předmětů lze najít analogie mezi míšeňskými brakteáty, datovanými před rok 1288. Další brakteátové víčko s míšeňským motivem lva pochází ze saského hadu Groitzsch (hmotnost $15 \mathrm{~g}$, průměr $45 \mathrm{~mm}$, výška $18 \mathrm{~mm}$ ). Tentokrát nese obraz stojícího lva $\mathrm{s}$ analogiemi v motivech míšeňských brakteátů poslední třetiny 13. století (Hrubý a kol. 2006, 247-248, obr. 47:19). Poškozená, ale téměř kompletní dvojdílná schránka na brakteáty pochází z durynského hradu Jenalöbnitz, ta je na obou miskách, hluboké i plytké, opatřena opisem kolem vyobrazení doleva kráčejícího lva. Artefakt je zařazen mezi léta 1270-1310 s odkazem na míšeňské ražby Jindřicha Jasného před rokem 1288 (Stoll 1993, 70, Taf. XXVII:14).

Vedle brakteátového víčka je stříbrná mince (B 202; obr. 20) dalším monetárním dokladem $\mathrm{z}$ areálu hradu. Ve dvojím opisovém pruhu, odděleném dvojím perlovcem je vyobrazena česká

21 Erich manuscriptorium Liber vaticus, Cestovní breviář litomyšlského biskupa a kancléře Karla IV. Jana ze Středy. Dostupné z: http:// v2.manuscriptorium.com/apps/main/index.php?request=request_document\&docId=set04052422, cit. 14. 2. 2019. 

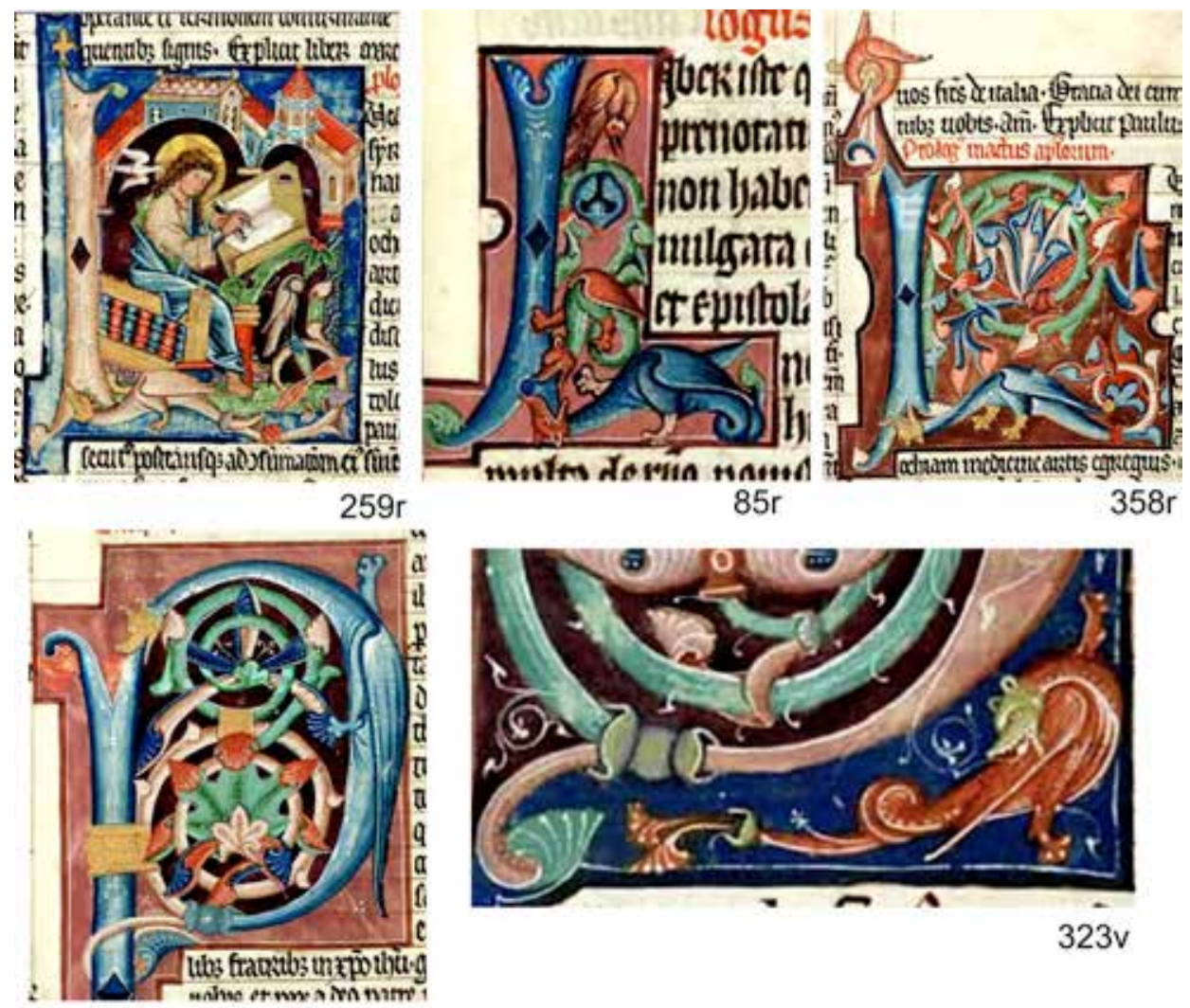

$339 r$

Obr. 21. Př́íklady zobrazení draka ve Františkánské bibli (70.-80. léta 13. století), Knihovna Národního muzea v Praze, sign. XII.B.13. Dostupné z: http://v2.manuscriptorium.com/apps/main/en/index.php?request=request_document\& docId=set031101set 4134 .

Abb. 21. Beispiele für die Darstellung eines Drachens in der Franziskanerbibel (siebziger-achtziger Jahre 13. Jhdt.), Bibliothek des Nationalmuseums in Prag, XII.B.13. Abrufbar unter: http://v2.manuscriptorium.com/apps/main/en/index. php?request=request_document\&docId=set031101set4134.

koruna. Opis zní: +wencezlaus secundus +dei: gratia:rex:boemie. Na reversu je zobrazen český lev kráčející doleva v perlovci s opisem *+*grossi pragenses. Obraz lva je setřelý v místě hřívy, která se skládá ze dvou řad protilehlých půlměsíčků. Pražský groš Václava II. představuje Smolíkův typ 1 (Smolík 1971, 11-12; Hásková 1991, 15-25). Průměr mince dosahuje 27,1 mm.

\section{Interpretace lokality v kontextu výpovědi písemných pramenů a historického vývoje Broumovska}

Na základě výše představeného rozboru vybraných keramických a kovových artefaktů lze část položek zařadit do širšího časového rámce 13.-16. století. Přesto nám několik artefaktů dovoluje soubor přesněji chronologicky zařadit. V prvé řadě se jedná o dva numismatické nálezy. Pro tzv. brakteátové pouzdro (B 201) je možno najít analogii mezi míšeňskými brakteáty datovanými před rok 1288. Druhý nález - pražský groš Václava II. (B 202) pak můžeme přiřadit počátečním letům 14. století. Mezi chronologicky citlivější předměty patří i ostruhy. Zastoupené typy umožňují zařazení do období od druhé poloviny 13. století až počátku 14. století. Obdobné 
časové určení umožňuje rovněž nákončí opasku s vyobrazením draka (B 190). I další (sice méně chronologicky citlivé) kategorie kovových nálezů (srpy, podkovy, udidla, hřebla, třmeny, hlavice palcátu, dýka) neodporují zařazení lokality do časového rámce od druhé poloviny 13. století až do průběhu 14. století. Pro keramické nálezy rozčleněné do tř́i skupin je možno dohledat analogie v souborech pocházejících z lokalit severovýchodočeského regionu, jejichž provoz je obecně datován od průběhu druhé poloviny 13. století až po celé století následující. Mezi chronologicky citlivější keramické nálezy lze přiřadit tři fragmenty konvice se třmenovým uchem. Celkově tedy lze soubor datačně zařadit do průběhu druhé poloviny 13. století až počátku 14. století.

Pouze nález podkovy (B 66) a ostruhy (B 198) chronologicky odpovídají mladšímu období. Jejich výskyt $\mathrm{v}$ okolí lokality lze spojit s využíváním cesty vedoucí od vesnice Božanov dále přes hřeben Broumovských stěn do Passendorfu (Pasterka) v Kladsku, kterou popisuje a kresebně zaznamenává i Hesseliův Broumovský urbář. Ostruhu př́ípadně i s lovem, který uvádí opět Broumovský urbář (Koláčný-Steinová-Waage 2017, 172).

Pro sledovanou oblast Broumovska a jeho okolí lze nejstarší písemné zprávy řadit do období počátku 13. století. Do roku 1213 se hlásí listina, podle které král Přemysl Otakar I. na žádost břevnovského opata Chunona daroval polický újezd, označovaný v listině za pusté místo, břevnovskému benediktinskému klášteru (CDB II, 399-401 č. 367; srov. Šimák 1936, 575-576). I když byla listina identifikována jako falzum, badatelé zároveň předpokládají její hodnověrnost alespoň v základní informační rovině (Novotný 1928, 622, pozn. 1; Preiss-Vilímková 1989, 39, 277; Čechura-Ryantová 1992, 81, 82; 1993, 198-199; Šrámek 2009, 13-37; 2013, XXXIII-XLV; 2015, 13-42). Polický klášter, který měl vyrůst okolo starší poustevny s kapličkou, je písemnými prameny doložen mezi lety 1250-1267 (CDB V/1, 127 č. 65, 377-379 č. 246; srov. Tomek 1857, 208; 1881, 13; Šimák 1938, 893; Hladký 2004, 71-72). Právě odtud byla vedena další expanze za masiv Broumovských stěn, na Broumovsko (Žemlička 1998, 261-263; 2002, 235). Roku 1253 byl do Police přeložen královskou listinou ${ }^{22}$ trh z klášterní vsi Provodov (CDB IV/1, 483-484 č. 289). Zmíněná písemnost pak přičítá králi Přemyslu Otakarovi II. také potvrzení nadání Policka břevnovskému opatovi Martinovi I. Z doby okolo roku 1255 pochází unikátní pamětní zápis vymezující hranice polického zboží vůči statkům pánů Petra a Rubína, rodu erbu třmene (CDB V/1, 127 č. 65). Po roce 1250 pak disponujeme dalšími důležitými zprávami. Opat Martin I. totiž povolal kolonisty a postoupil jim část území mezi stěnami a říčkou Stěnavou k osídlení. V rozmezí let 1255-1256 tak byly vysazeny vsi Hynčice, Křinice, Božanov, Velká Ves, Hejtmánkovice a další (CDB V/1, 106 č. 51, 107 č. 52, 137 č. 72, 138 č. 73, 173 č. 98). Písemně je Broumov poprvé doložen k roku 1256 jakožto trhová ves či městečko (RBM II, 35 č. 91; RBM II, 76-77 č. 191; resp. CDB V/1, 138 č. 73, 258 č. 162; srov. Hladký 2003, 10), jako město je uváděn až k roku 1296 (RBM II, 743 č. 1732). Dokladem expanze benediktinů za stěny je další podvržená listina, hlásící se do roku 1260. Podle ní měl král Přemysl Otakar II. nařídit, aby bylo Policko vyňato z pravomoci královských úředníků a aby podléhalo jen opatovi břevnovského kláštera (RBM II, 106-107 č. 276; CDB V/1, 377-379 č. 246; srov. Žemlička 2014, 138).

Klíčové datum v břevnovském úsilí o opanování Broumovska představuje rok 1258, tehdy pražský biskup Jan III. udělil břevnovskému opatu Martinovi právo užívat výnosů broumovské fary a dosazovat sem duchovní správce bez zvláštního stvrzení od biskupa (CDB V/1, 258-259 č. 162). Roku 1266 pak břevnovský konvent odkoupil od fojta Wichera fojtství v Broumově se všemi právy a důchody k němu náležejícími (CDB V/1, 707-708 č. 477). K tomuto fojtství nejspíše krom Broumova přináleželo přibližně od poloviny 13. století také několik vsí v okolí. Skutečnost, že zisk broumovského fojtství stvrzovali nejvyšší komoří a maršálek, je další indicií, proč hledět na údajnou listinu Přemysla Otakara II. z roku 1260, svěřující severovýchodní Čechy výhradně pod správu benediktinů, s nedůvěrou. Zdejší benediktinské panství se nepochybně ustavovalo a rozšiřovalo postupně, nebylo tedy od počátku dáno údajným privilegiem $\mathrm{z}$ roku 1213. Až 60. léta 13. století tak lze považovat za dobu, kdy byla benediktinská správa na českém severovýchodě konsolidována a právně zajištěna. V průběhu 50. a 60. let 13. století tedy zeslábla

22 Jedná se o formálně zfalšovanou listinu (tj. listinu, která vznikla v jiné době, než do které se sama hlásí), která je však po obsahové stránce považována za věrohodnou (Šebánek-Dušková 1963, 22-23; Žemlička 2002, 427; 2014, 55, 272). 
dřivější vazba severovýchodních Čech ke Kladsku a kladskému arcijáhenství, břevnovská kolonizace na severovýchodě Čech také vyústila ve zformování broumovského děkanátu (Musil 2012, 317-331). ${ }^{23}$ Policko i Broumovsko měly od druhé poloviny 13. století vlastní správu, ač obojí podřízenou Břevnovu. Pro Policko představoval prodlouženou ruku břevnovských benediktinů probošt, na Broumovsku to byl broumovský fojt. ${ }^{24}$

Za bezvládí po smrti krále Přemysla Otakara II. došlo v letech 1279-1290 k zastavení Broumovska ve prospěch vratislavského vévody Jindřicha IV. Proba (FRB II, 333; Musil 2003, 71). Po upevnění vlády mladého Václava II. a v prvé řadě po smrti vévody Jindřicha IV., jemuž římský král Rudolf Habsburský doživotní držbu Kladska potvrdil, se Broumovsko navrátilo na základě vévodovy závěti zpět do držení břevnovských opatů (RBM II, 652 č. 1514). Obtížným časům ale neměl být ani po konsolidaci zeměpanské moci konec. František Krásl a Jan Ježek se zmiňují (bohužel bez detailů a patřičných odkazů) o nepokojích a potížích se sousedy a vzpurnými poddanými, které v této době Broumovsko zachvátily. Právě proto došlo k angažmá Konráda ze Sulzu a Vyšemíra z Nečtin coby purkrabích (Krásl-Ježek 1898, 353). Snad lze uvažovat o nějakých důsledcích držby vratislavského knížete, ovšem vzhledem k absenci hodnověrných svědectví je toto čirou spekulací. Rytír Konrád ze Sulzu byl najat opatem Bavorem coby kastelán sídla ${ }^{25}$ při městě Broumově roku 1296 (RBM II, 743-744 č. 1732). Rytír Konrád měl za úkol opatřit toto sídlo ${ }^{26}$ posádkou a dostatečně je bránit. Pokud by se vzdálil, slíbil Konrád zanechat sídlo osazené silnou posádkou. V př́ipadě války mezi českým králem a polskými knížaty, pokud by ho nebyl schopen ubránit sám bez pomoci, nesměl sám povolat pomoc bez toho, aby to schválil břevnovský opat. Správce sídla měl být sice ochráncem práva, přitom si ale nesměl uzurpovat soudní pravomoci, pokud by mu to opat neurčil po svém vyslanci či ve svém dopise. Při soudních sporech měl vždy stát na straně broumovského fojta (RBM II, 743-744 č. 1732). Po něm (tj. patrně od roku 1297) zastával stejný post ${ }^{27}$ Vyšemír z Nečtin, bratr opata Bavora (RBM II, 1208-1209 č. 2765).

Existence broumovského kastelána a vymezení jeho pravomocí od správy a zajištění opevnění definované písemným pramenem jako municio představuje strukturovanou a potřebnou vojenskou správu a zajištění oblasti. Vojenská funkce a její striktní vymezení a kontrola opatem poukazuje již na zkušenost kláštera s problémy, které přináší vojenské zajištění této nebo jakékoliv jiné oblasti. Omezení samostatného počínání v navyšování ozbrojenců i v době nebezpečí je silnou pojistkou a viditelným strachem kláštera možná jen k postavě Konráda ze Sulzu nebo celkově k purkrabskému úřadu, který evidentně mohl rychle svou sílu obrátit proti vlastnímu pánovi. Stávající municio muselo být pro opata zdrojem obav, a tím pádem poměrně kvalitním pevným vojenským bodem, který při neschváleném navýšení posádky je velkým nebezpečím. Vystřídání postav broumovských purkrabích, kdy opatův bratr Vyšemír mohl zklidnit tyto obavy kláštera, by mělo své opodstatnění. V hypotetické rovině lze konstatovat, že broumovské municio muselo splňovat několik strategicko-vojenských požadavků, a to ubytovací kapacitu pro vojenskou posádku a především purkrabího samotného, pro konec 13. století patrně disponovalo minimálně opevněním v kombinaci hlína, dřevo a patrně kámen, otázkou jsou nedoložené zděné konstrukce (Durdík 1999, 84; Vlček-Sommer-Foltýn 1997, 186; Čížek-Slavík 2002, 72) a centrální vojenská správa broumovského panství.

Opodstatnění existence broumovského kastelána dobře ilustruje událost z počátku 14. století. Roku 1300 totiž v době opatovy nepř́itomnosti broumovští fojtovée ${ }^{8}$ Lev a Tyček spolu s dalšími společníky vykradli pokladnu v polickém kostele. Opat Bavor si nechal oba fojty po

\footnotetext{
23 Podle Františka Musila vznikly vlivem osidlovací aktivity, podněcované po polovině 13. století břevnovskými benediktiny, farnosti Broumov, Božanov, Heřmánkovice, Martinkovice, Police nad Metují, Ruprechtice, Vernéřovice a Šonov.

24 Nikoliv purkrabí, jak soudil Václav Vladivoj Tomek na základě důvěry v existenci opevněného sídla v Broumově. To však podle listiny z roku 1296 vzniklo nedlouho před tímto datem z podnětu břevnovského opata Bavora z Nečtin (RBM II, 743-744 č. 1732). Jeho případné starší kořeny jsou zatím neprokazatelné.

25 V listině stoji „miunicio ac citivias Brunow cum toto territorio“.

26 Pramen používá důsledně formulaci ,municio“

27 Právě Vyšemír z Nečtin je v pramenech výslovně označen jako „castellanus de Braumow“, na rozdíl od Konráda ze Sulzu. Také v př́ípadě Broumova se již objevuje nejen termín ,civitas“, ale i „castrum“.

28 V originále ,advocati civitatis nostrae Brumow“.
} 
návratu z Říma zavolat $\mathrm{k}$ sobě do Police a po jejich př́íchodu je nechal zajmout a uvěznit. Leč neopatrností či snad přímým přičiněním strážců, jak naznačuje svědectví opata Bavora z Nečtin, zajatci utekli a spolu s dalšími vedli odbojnou válku proti klášteru a benediktinskému konventu škodili rozličným způsobem. ${ }^{29}$ Těžká zranění přitom utrpěl klášterní notář Jan, jemuž útočníci ukradli sumu 70 hřiven stř́bra, a purkrabí Vyšemír přišel o koně a zbroj. Od škod ovšem nebyli uchráněni ani broumovští měštané, ačkoliv se útočníkům nestavěli na odpor. Škody na sýpkách a dvorech dosáhly výše 200 hřiven stř́ibra. Následkem toho byli oba fojtové prohlášeni za psance. Přesto nadále neváhali plenit okolí. ${ }^{30} \mathrm{Když} \mathrm{však} \mathrm{v} \mathrm{čele} \mathrm{početné,} \mathrm{pramen} \mathrm{uvádí} \mathrm{přímo}$ 100 ozbrojenců, družiny vyloupili a vypálili klášterní ves Šonov a odehnali stáda, ${ }^{31}$ purkrabí Vyšemír proti povstalým fojtům vytáhl v čele hotovosti ${ }^{32}$ a porazil je. Odbojní fojtové s částí svých druhů byli zajati, avšak Lvovi se podařilo uprchnout. Jeho bratr Tyček byl z př́kazu purkrabího Vyšemíra smýkán po broumovském náměstí přivázán $\mathrm{k}$ ocasům koní a poté uvržen do kobky, kam jej posléze následoval i znovu lapený Lev. Viníkům byl také konfiskován majetek, broumovská rychta se sedmi vesnicemi připadla opatovi (RBM II, 1207-1209 č. 2765; srov. Preiss-Vilímková 1898, 41; Žemlička 2014, 145-146; Šrámek 2017a, 79-103).

Celou kauzu ovšem známe toliko optikou opata Bavora z Nečtin, který napadený Broumov označuje jako město a hrad (castrum; RBM II, 1207-1209 č. 2765). Hrad byl zapálen a chudina učinila v Broumově škodu za 200 hřiven. ${ }^{33}$ Již Rudolf Urbánek varoval před nebezpečím jednostranného pohledu tohoto pramene. Zdá se, že celá událost tkví v loupežném přepadení, jeho potrestání a následné mstě, nelze se nepozastavit nad rozsahem nepokojů na Broumovsku roku $1300 .{ }^{34}$ Takto uvažoval i Rudolf Urbánek, který nepokládal krádež peněz z polického kostela za hlavní př́íčinu. Události, které vyvrcholily otevřeným střetem s klášterní vrchností, považoval za cílevědomou rebelii proti opatu Bavorovi, zapříčiněnou krácením práv broumovských fojtů i ostatních rychtářu na Broumovsku ze strany benediktinů. Loupež peněz byla podle Urbánka aktem nespokojenosti s výší desátků, jimiž opat Bavor financoval své nákladné a ambiciózní plány (Urbánek 1948, 505-508). Třebaže celkový obraz opata Bavora jako velkého falzifikátora a konspirátora, který Rudolf Urbánek ve svém rozsáhlém díle vykreslil, není př́íliš přesvědčivý a rovněž vede k opatrnosti v úsudcích (Šrámek 2010, 16-33), i př́ípad povstání broumovských fojtů může být odrazem konstituování benediktinského panství v severovýchodních Čechách. Inspirativní je také Urbánkův poukaz na možnou spojitost bratrů Lva a Tyčka s rodem Pannewitzů na základě toho, že jméno Tyčko se v tomto rodě opakovaně objevilo (Urbánek 1948, 426, pozn. 772; srov. Jurek 1996, 263-264). Podle mínění Františka Musila se fojtové z Broumovska během přičlenění Broumovska ke Kladsku seznámili s postavením tamních fojtů, kteří byli považováni na rozdíl od Čech nikoliv za poddané, ale za nejnižší př́íslušníky šlechty, což jim skýtalo jistý profit, a právě proto došlo posléze ke střetu s patrně autoritativním opatem Bavorem (Musil 2016, 159-160). ${ }^{35}$

Literatura soudí, že po neblahých zkušenostech s povstáním broumovských fojtů nechal opat Bavor z Nečtin mezi lety 1301-1305 vystavět v Broumově nové opevněné sídlo ${ }^{36}$ (RBM II, 1203-1204 č. 2752; srov. Šimák 1936, 582; Č́í̌ek 1995, 17-28; Č́́žek-Slavík 2002, 72; Kovář

\footnotetext{
29 Opatská relace je bohužel v tomto směru nekonkrétní, používají se tu termíny jako „maleficium“ a „multa mala“.

30 Opět nekonkrétně je zmiňováno toliko Broumovsko, v originále ,in prouinciam Braunensem“.

31 V originále ,villam monasterii Schonow incendio cremarent“ (RBM II, 1207-1209 č. 2675).

32 V roce 1305 kladský purkrabí Beneš z Vartenberka dosvědčil, že získal za své zásluhy od opata a konventu břevnovského kláštera ves Provodov se dvorem (RBM II, 876 č. 2024). Pavel Preiss a Milada Vilímková usoudili, že těmi zásluhami byla pomoc př́i potlačení rebelie fojtů, nelze to ale verifikovat (Preiss-Vilímková 1989, 41).

33 „Civibus autem civitatis Braumow se non opponentibus nec se defensioni offerentibus praedicti malefici de civitate sine molestia recesserunt, ut postea tam in grangiis quam in curiis et alodiis et in alodiis et in succensione castri Braumow et in damnis pauperibus illatis ad duo milia marcarum provinciam damnificaverunt. Unde propter tanta facinora per sententiam juratorum civitatis Braumow et totius provinciae scultetorum nec non et aliorum nobilium virorum judicati et condemnati sunt similiter et proscripti juris (ordine) per omnia observato“ (RBM II, 1207-1209 č. 2765). Hrad Broumov byl zapálen, ale klášterní vesnice Šonov byla kompletně spálena „,incendio cremarent“ .

34 Vedle broumovských fojtů je zmíněna účast rychtářů z Martínkovic (Martinivilla) a Otovic (Ottonisvilla).

35 Doklad napětí mezi fojty a benediktinskou vrchností vidí František Musil například v listině opata Bavora pro hejtmánkovického fojta z roku 1296, v níž se sice na jedné straně garantuje zmíněnému fojtovi a jeho dědicům držba rychty, ale listina obsahuje též pasáže definující povinnosti fojta vůči klášteru v rovině peněžních plateb, odvodu naturálií i vojenské služby (RBM II, 741-743 č. 1730).

36 Zde pramen výslovně používá termín „castrum“.
} 
2010, 75-76). Archeologický a stavebně-historický průzkum však zatím nevnesl větší světlo do torzovité výpovědi písemných pramenů, zdá se ovšem, že celý proces zahrnoval delší dobu, než se dosud soudilo. Gotická podoba broumovského kostela totiž podle posledních názorů pochází až ze tř̌etí čtvrtiny 14. století (Slavík 2014, 31; Musil 2016, 166-167). Nové opevněné sídlo mělo být dle T. Durdíka (2006, 117-122) spolu s jeho strategickou polohou hlavním důvodem povýšení významu Broumova, a tedy přesunutí centra regionu z Police za stěny, když se Broumovsko začalo osamostatňovat na původním zázemí kolonizace severovýchodních Čech, na polickém proboštství, které postupně ustoupilo do pozadí. Zároveň se zdá, že výstavba broumovského castra tvořila součást širších snah o zabezpečení benediktinského panství v severovýchodních Čechách v oné době (Č́ižek-Slavík 2002, 74-78; Horák 2002, 220-226; Novák 2005, 167-170). Výstavba hradu představuje možnou restrukturalizaci panství a přehodnocení vojenského potenciálu opevnění na jeho území. List opata Bavora uvádí po roce 1300 vedle měštanů z Broumova a šoltysů na Broumovsku i šlechtu, kterou ale jmenovitě neznáme, jen chyceného rytíře de Staf, podporovatele Tyčka a Lva (viz pozn. 32).

Ani první desetiletí 14. století nebyla na Broumovsku příliš klidná. V době bojů o český trůn po vymření Přemyslovců se Broumov stal mezi lety 1307-1308 načas jedním z míst, kde nalezly habsburské oddíly zázemí (FRB IV, 113). Není jasné, jestli z toho lze dovozovat př́mou podporu Habsburků břevnovským opatem, nebo zda se spíše jednalo o více méně vynucené poskytnutí prŕístřeší vojákům. Kronikáři 14. století sice vykreslují habsburskou kampaň v černých barvách, přitom se ale zdá, že se římský král Albrecht Habsburský se synem Fridrichem snažili nepřitěžovat českým městům a venkovu, ale zajištovali zásobování svého vojska ze svého zázemí (Antonín 2009, 25-28). Poté, co většinu Slezska opanoval v letech 1327-1335 Jan Lucemburský, přestal být region Broumovska a Kladska nárazníkovým pásmem, jak konstatoval Ondřej Felcman. Podle jeho mínění se s tím, jak se oblast přesunula spíše k centru svazku zemí Koruny české, změnil i náhled panovníka na pozici Kladska, které bylo často zastavováno, čímž král Jan připoutával slezské vévody ke koruně. Toho osudu bylo Broumovsko ušetřeno, byt' nikoliv s absolutní platností (Felcman 2017, 135).

Roku 1331 král Jan Lucemburský zastavil město i panství Broumov, očividně v důsledku potřeby prostředků spojených s jeho italskou politikou, bratrům Wolframovi a Matějovi z Pannewitz (RBM III, 690 č. 1763). ${ }^{37}$ Zajímavé je, že Pannewitzové byli držiteli Homole v sousedství Broumova, čímž byly oba majetky sjednoceny v jedněch rukou (Felcman 2017, 135). List krále Jana, daný 10. června v Pavii, opatovi a konventu zaručil, že statky kláštera ve městě Broumově a okolí připadnou po smrti obou bratří, jimž bylo panství zastaveno, Břevnovu nazpět, což oba Pannewitzové přijali. Po jejich úmrtí se tak skutečně stalo. František Musil upozornil na skutečnost, že třebaže bližší podrobnosti o okolnostech zástavy neznáme, v původní zástavní listině byla patrně pasáž o tom, že po smrti zástavních držitelů připadá zástava (tj. benediktinské Broumovsko) zpět králi. To pak Musil vykládá jako př́ípravu půdy pro opakovanou zástavu, at' už ze strany krále, či Pannewitzů (Musil 2016, 162-164). Nebezpečí opakované zástavy, která mohla skončit až faktickým zcizením dotyčného zboží, si byli benediktini jistě dobře vědomi, a proto konvent napřel prostřednictvím svého představeného všechny síly k tomu, aby tuto hrozbu eliminoval. Ondřej Felcman se naopak neztotožňuje s představami části literatury, pod níž zástava Broumovska Pannewitzům znamenala či předznamenala jeho potenciální opětovné sjednocení s Kladskem (Šůla 1996, 27-28). Felcman správně upozorňuje, že Pannewitzové vystupovali coby královští manové, nedrželi ani celé Kladsko, ani Broumovsko a i sama zástava měla posléze dočasný charakter. Ondřej Felcman proto soudí, že oba bratři jen využili panovníkovy známé finanční nouze, aby si sáhli na sousední území, které představovalo coby zboží podléhající královské komoře vcelku snadnou kořist (Felcman 2017, 136).

37 Šlechtický rod Pannewitzů sídlil ve Slezsku a původně pocházel z Horní Lužice, z Pannewitz pod Bischofswerdou. Ve 14. století byl tento rod již velmi rozvětvený. Z hlohovské linie vzešla větev, která se usadila v Kladsku. V roce 1327 obdrželi bratř̌i Pannewitzové Wolfram, Matěj a Tyček od Jana Lucemburského za věrné služby patronát kostela v Rengersdorfu (dnes Krosnowice) pod Kladskem. V Kladsku pak dosáhli úspěchu a Wolfram se dokonce stal kladským purkrabím. Viz Jurek 1996, 263-264. 
I přes tyto zásahy ze strany panovnické komory lze dobu opata Bavora z Nečtin i jeho nástupců charakterizovat jako období rozkvětu. Roku 1348 totiž dosáhl opat Předbor z Chroustoklat na Karlu IV. obdaření Broumova právy královských měst Hradce a Kladska (CIM IV/1, 97-98 č. 61). Na žádost konventu pak roku 1359 Karel IV. broumovským měšt’anům zakázal obehnat město hradbami a př́kopy proti opatově vưli. O obehnání Broumova přitom začala městská rada uvažovat zřejmě již roku 1348 v důsledku Karlova privilegia (Čížek 1995, 17). Avšak už o rok později nastoupil do úřadu nový opat Diviš I., který odmítavé stanovisko svého předchůdce nesdílel. A tak v letech 1360-1380 došlo k obehnání Broumova kamenným opevněním, které zahrnovalo i objekt kláštera, hradu a farního kostela. ${ }^{38}$

Z výše uvedeného historického přehledu je zřejmé, že v časovém horizontu, kam lze klást provoz zkoumané lokality, byli pány oblasti broumovští benediktini (vyjma období zástavy 1279-1290 Jindřichu IV. Probovi). Právě do souvislosti s benediktinskou držbou, respektive kolonizací, a majetkovými poměry je tedy patrně nutné klást vznik a provoz božanovského hradu. Tuto hypotézu lze podpořit řadou skutečností. Zásadním faktorem je již výše popsané umístění lokality v krajině Broumovska. Nevelký hrad byl vystavěn v př́íkrém severním srázu Broumovských stěn. Tato poloha je dobře viditelná ze všech vsí východní části broumovského panství včetně samotného centra dominia, tedy města a kláštera v Broumově.

Nevýhodou této lokace však byla absence prostoru pro rozvinutí hospodářského zázemí sídla, které se skládalo pouze z jádra a níže položené nevelké plošiny. Zásobování sídla tak patrně muselo probíhat $\mathrm{v}$ závislosti na centrálním místě panství, patrně v závislosti na vesnici Božanov (v majetku kláštera zmíněna od roku 1255). O spojení obou sídel svědčí i již popsané zaniklé komunikace směřující od vsi k hradu. Severní cesta směřovala podél Studeného potoka a ústila prŕmo do prostoru mezi jádrem hradu a plošinou. Tato komunikace byla zčásti zaříznuta do strmého říčního koryta. Druhá cesta je tvořena svazkem úvozových cest, které probíhají jižně od hradu a pokračují dále přes hřeben Broumovských stěn do Kladska. Průběh obou těchto cest se spojoval na úpatí stěn a pokračoval dále do vsi Božanov. Jiří Sigl $(1991,98)$ vyslovil domněnku, že hrad byl vystavěn $\mathrm{v}$ rámci kolonizace směřující z Kladska. S tímto tvrzením však nelze souhlasit. Těžko si lze představit situaci, kdy by sídlo založila vrchnost z kladské strany bez jakékoliv hospodářské opory. Tento počin by znamenal zásobovat provoz sídla přes hřbet stěn. Samo sídlo by bylo jedinou osamocenou výspou této snahy kontrolovat východní Broumovsko, nebot' prostor pod hradem (Božanov, Martínkovice, Křinice) byl již kolonizován a v držení benediktinů nejpozději od 50 . let 13 . století. Od počátku založení sídla by navíc celý podnik probíhal doslova pod dohledem vrchnosti ze samotného Broumova vzdáleného $8 \mathrm{~km}$. Představu, že by se mohlo jednat o lokalitu předcházející kolonizačnímu úsilí benediktinů, je rovněž nutno odmítnout, nebot' nálezový inventář nelze chronologicky zařadit do období před polovinou 13. století.

Při posuzovaní důvodů založení a provozu lokality, ke které neexistují přímé písemné doklady, je nutné pracovat $\mathrm{s}$ historickým vývojem oblasti a pokusit se najít časově a typologicky obdobné opevněné polohy. Jako nejpravděpodobnější se jeví hrad u Božanova dát do spojitosti s osídlovacím procesem vedeným broumovským klášterem. Netypické založení uprostřed příkrého svahu stěn bylo zvoleno záměrně. $Z$ tohoto prostoru bylo sídlo dobře dohledné $\mathrm{z}$ větší části Broumovska a zároveň bylo umístěno na samý jihovýchodní okraj benediktinské sídelní oikumeny, která byla tvořena vysazením nových vsí v průběhu 50. a 60. let 13 . století.

Z lokality bylo možné kontrolovat vstup do Broumovské kotliny od východu a díky své poloze byla zároveň na značnou vzdálenost dobře viditelná ze sousedních panství. Hrad tedy mohl představovat pomyslný hraniční bod vymezující majetek kláštera vưči přilehlému Kladsku. Právě otevřenost Broumovské kotliny na severozápad do Javorska a Svídnicka a na jihovýchod do Kladska byla slabinou celého prostoru, kterou představovalo i zastavení Broumovska Jindřichu IV. Probovi nebo později králem Janem v první polovině 14. století rodu Pannewitzů.

38 Toto opevnění se do dnešních dnů jako celek nedochovalo, neocenitelným pramenem o jeho podobě jsou proto ikonografické prameny, viz SOkA NA, MÚB, Sbírka fotografií a reprodukcí rytin Broumovska 1609-1937, inv. č. 1-5, f. 1. 
O tom, že se jednalo spíše o strážní bod, svědčí i podoba samotného sídla a skladba nálezového inventáře, který vypovídá o silném zastoupení standardně řemeslně zručné vojenské posádky. Nevelké sídlo, jehož jádro bylo vymezeno příkopem, bylo doplněno o níže položenou a z údolí lépe dostupnou plošinu, kam bylo dle nálezů umístěno patrně nevelké hospodářské, respektive provozní zázemí sídla. V centrální části hradu zřejmě stávala dřevěná stavba plnící hlavní obytnou i obrannou funkci, jak na základě svého výzkumu usuzoval již J. Sigl $(1991,97)$. Vzhledem k rozsahu lokality a zejména vzhledem k jejímu umístění mimo osídlení nelze počítat se správní funkcí. O př́itomnosti spíše vojenské družiny svědčí zejména skladba nálezů spojitelná s ustájením koní a jejich výstrojí.

V severovýchodních Čechách lze najít více podobných lokalit, které spojuje řada analogických faktorů. V prvé řadě se jedná o nepř́iliš kvalitně založené opevnění, které využívá kombinaci prríkopů a lehčí formu fortifikace. Rovněž rozsah těchto sídel není veliký a zpravidla se jedná pouze o jednodílné, popřípadě dvoudílné dispozice $s$ jádrem a předhradím. Typická pro ně je i větší vzdálenost od tehdejších center osídlení a umístění na okraji tehdejší sídelní oikumeny. Krátkodobost provozu se pak může odrazit v pouze jednom sídlištním horizontu. V Podkrkonoší se jedná např́íklad o sídla Bezník u Borku (Benešová 1991), Bolkov u Zlaté Olešnice (Hejna 1962), Hajnice-Kyje (Wolf-Sigl-Jirásek 1987), Horní Vlčice u Trutnova (Sigl-Wolf 1983a), Hradiště u Horních Štěpanic (Sigl-Wolf 1989), Rechenburk u Libče (Wolf 1977; 1983), Starý zámek u Radvanic (Hejna 1969) či Šluspárk u Úhlejova (Sigl 1980). Vladimír Wolf (1998, 107-116) pro tyto lokality používal označení tzv. kolonizační provizoria a dával je do souvislosti s vytvářením panství a zajištěním jejich hranic. Po stabilizaci majetkových poměrů pak tyto fortifikace měly být opouštěny. Tento pojem, respektive typ lokalit je znám i z jiných oblastí Čech a Moravy, ačkoliv doposud není úplně definován a v různých regionech může nabývat rozdílných podob (srov. Bolina-Doležel 1988, 328-330; Kouřil-Plaček 1985, 125; Musil 1995, 30-31; Plaček 1996, 31; Velímský 1979). Část z výše uvedených lokalit (Bolkov u Zlaté Olešnice, Hajnice-Kyje, Horní Vlčice u Trutnova, Starý zámek u Radvanic a Rechenburk u Libče) bývá dávána do souvislosti s budováním dominia rodem Švábeniců na Trutnovsku (Jansa 2004; Musil 2009, 332). Opevněná sídla Bezník u Borku a Šluspárk u Úhlejova pak patrně souvisí s osídlováním Miletínska na Jičínsku (Drnovský 2013, 27-28). V nedávné době pak D. Kovář $(2018,96)$ podobně interpretoval stř̌edověkou fortifikaci u Senožat (okr. Pelhřimov) jako lokalitu založenou želivskými premonstráty s možným cílem zajištění okrajové části svých majetků.

Pakliže se podíváme na sousední polický újezd, jenž byl rovněž v majetku benediktinů, kteří se podíleli na jeho osídlování, tak i zde lze najít analogické lokality, které s božanovskou lokalitou spojují společné znaky. Jedná se o umístění v krajině při kraji sídelní oikumeny a zároveň na hranici se sousedními majetkovými celky. Uvést lze opevněné polohy Homole u Dřevíče, Bystrý (někdy též nazývaný hrad u Stárkova) a Vlčinec. Pro všechny tři lokality rovněž bohužel postrádáme písemné prameny pro klíčové období druhé poloviny 13. století a počátku 14. století, kdy se polická benediktinská doména (obdobně jako sousední broumovská) konstituuje.

Sídlo umístěné pod vrch Homole na úzké šíji mezi řekou Metují a potokem Dřevíč představuje lomem poškozenou fortifikaci. Lokalita byla obehnána zdvojeným př́ikopem na severní straně a valy, které chrání centrální plošinu. Toto sídlo nebylo v písemných pramenech - na rozdíl od nedalekého dvora - písemně zmíněno (Novák 2004, 166). Hrad Bystrý je vymezen západním šíjovým příkopem, valem a centrální lichoběžníkovou plošinou. Z jižní strany chrání vnitřní areál také příkop s valem. Sídlo dále využívalo přírodní srázy. Archeologickým výzkumem byla doložena stavba dřevěné konstrukce založená na kamenných základech na centrální plošině. Vznik hradu je datován do druhé poloviny 13. století a zánik požárem do průběhu 14. století. V nálezovém souboru kovových předmětů absentují militaria (Tichý-Tůma-Wolf 1999, 111-112; Musil 2006, 222). Poslední jmenovanou lokalitou je hrad Vlčinec. Jedná se o sídlo s výrazným zemním opevněním, ale i dokladem zděné stavby. Fortifikace byla situována na dlouhé a úzké ostrožně nad soutokem Metuje a Hlavňovského potoka na velmi specifickém stavebním místě, které výrazně definovalo jeho vzhled. Hrad byl opevněn zdvojeným šíjovým příkopem na severu. Úzké hradní jádro obsahovalo hranolovou věž a jižně od ní byla plošina chráněná z jihu 
a východu valem a př́ikopem. Časové zařazení lokality kombinuje v současné době písemné a archeologické prameny. Její existence spadá do první poloviny 14. století (Čížek-Slavík 2002, 76; Horák 2002, 220-226; Novák 2004, 168).

S určitou dávkou opatrnosti (uvědomujeme si nutnost dalšího studia pro obě lokality) lze klást vznik a provoz všech uvedených sídel do období od druhé poloviny 13. století až do průběhu století následujícího. K tomuto závěru nás vede obdobná forma převážně zemních fortifikačních prvků a umístění na okraj polického újezdu. V této lokalizaci v hranicích újezdu bychom mohli spatřovat snahu kláštera v Polici nad Metují zajistit budované dominium.

Hrad u Božanova mohl být založen s podobným záměrem. Hranice Broumovska, respektive okraj nově vzniklé sídlištní oikumeny broumovského kláštera, bylo potřeba vymezit vůči sousednímu Kladsku. Zbudování nevelké, přesto však dominantní opevněné polohy na samé hranici klášterního majetku mohlo představovat z pohledu benediktinů optimální řešení, kterým by se zamezilo nejen př́ípadným kolonizačním podnikům z Kladska. Na sídle lze pak počítat s př́itomností nevelké posádky, která by zajištovala především vojenskou funkci sídla, jež bylo jinak závislé na hospodářském spojení s klášterními vesnicemi na úpatí Broumovských stěn.

Předpokládáme-li, že hrad nad Božanovem sloužil výše nastíněnému účelu, vyvstává pochopitelně otázka, zda se jednalo o jedinou takovou fortifikaci na Broumovsku, nebo zda jich bylo vybudováno více. Při terénní prospekci v roce 2018 byla objevena další opevněná lokalita. Opevnění je oválného půdorysu a představuje plošinu doplněnou příkopem a valem. Tato fortifikace byla založena v analogických podmínkách jako Božanov (svažující se hřbet, který tvoří zemskou hranici) s tím rozdílem, že je situována na protilehlém konci Broumovské kotliny. Rozměry a charakterem fortifikace (dochovaly se poměrně výrazné zemní relikty) se rovněž blíží božanovskému sídlu. Dohlednost z opevnění zaujímá severní část Broumovských stěn, které jsou skryté výhledu z Božanovského hradu. ${ }^{39}$

Pakliže obě fortifikace fungovaly ve stejném časovém horizontu, jedná se o velice kvalitní strategické pozice v hraničních oblastech broumovského panství, které díky dohlednosti v krajině mohly kontrolovat kompletně celou Broumovskou kotlinu.

Konec provozu božanovského sídla může souviset $\mathrm{s}$ odbojem broumovských fojtů v roce 1300 a následujícími událostmi včetně výstavby hradu v Broumově. O průběhu těchto událostí jsme zpraveni z dokumentů opata Bavora $\mathrm{z}$ Nečtin, které zmiňují škody na klášterním majetku. O náhlém zániku božanovského opevněného sídla svědčí mimo jiné rozsáhlý soubor kovových předmětů, které byly ponechány na lokalitě, tedy nebyly odneseny. Tuto hypotézu nastínil již vedoucí zjištovacího výzkumu z roku 1991 J. Sigl (1991, 98). Dokladem násilného ukončení provozu hradu je zejména rozsáhlý soubor hrotů šípů a střel, které byly nalezeny během různých v podstatě nesystematicky vedených průzkumů za pomoci detektoru kovů. Část artefaktů sice byla odevzdána do královéhradeckého muzea, bohužel je nutné předpokládat, že velká část nálezů (nejen) militarií se nachází i v soukromých sbírkách.$^{40}$ Důvody, proč nedošlo k obnovení sídla po zlomení odporu fojtů, lze spatřovat ve více faktorech. Mohlo se ukázat, že hrad z vojensky strategického hlediska není schopen odolat cílenému obléhání vedenému $\mathrm{z}$ výše položených svahů stěn. Na počátku 14. století již patrně byly i hranice broumovského klášterního majetku konsolidovány a původní smysl fortifikace již pozbyl platnosti. Obdobné typy lokalit, které bývají označovány jako tzv. kolonizační provizoria, rovněž zanikly v době stabilizace panství. Násilný zánik kolem roku 1300 mohl pro božanovský hrad představovat pomyslnou poslední ránu. Do souvislosti s neobnovením lokality je nutné dát i budování fortifikace př́mo v centru Broumova. Zkušenosti opata s boji roku 1300 mohly přispět k poznatku, že je již zbytečné provozovat vzdálený opevněný bod, který v případě ohrožení samotného kláštera nemohl výrazně pomoci. Naopak vyvstala nutnost vybudovat fortifikaci př́mo v areálu města a kláštera. Vznik

39 Jelikož se jedná o zatím v literatuře zcela neznámou lokalitu, rozhodli jsme se neuveřejnit její přesnou pozici v krajině, stejně tak jako její půdorys (jinak podobný hradu Božanov), aby nebyla ohrožena nelegálním detektorovým průzkumem. Lokalitě bude věnována dalši badatelská pozornost. Keramické nálezy získané při povrchovém průzkumu lokality spadají do stejného časového období jako božanovský soubor.

40 Dle ústního sdělení jednoho z nálezců L. Procházky je lokalita stále cílem nelegální detektorové prospekce. Mezi nejčetnější nálezy patří výrazné množství hrotů šípů dosahující údajně počtu až řádově stovek (!) kusů. Tyto artefakty bývají nacházeny zejména ve vyvýšených svazích jihovýchodně od hradu. 
(či přebudování) broumovského castra na počátku 14. století mohl znamenat, že se jevilo jako zbytečné obnovovat dobytý a pravděpodobně i poničený hrad nad vsí Božanov.

\section{Závěr}

Vyhodnocená kolekce keramických a kovových artefaktů z hradu Božanov představuje v kombinaci a kvantifikaci jednotlivých druhů a typů artefaktů dobře časově zařaditelný soubor vznikající v druhé polovině 13. století s ukončením na počátku 14. století. Zdánlivá necitlivost artefaktů podkov, ostruh nebo udidel a jejich identifikovatelných variant s vazbou na areál hradu nebo jeho předpolí se ukázala $\mathrm{v}$ jejich kvalitativním a kvantitativním zastoupení jako základní charakter souborů objevujících se ve zmiňovaném časovém horizontu s oporou ve stratifikovaných situacích na jiných, především hradních, ale i hornických lokalitách. Komplexní zhodnocení souboru nálezů $\mathrm{z}$ opevněného sídla vykazuje dosti obdobný projev v typové skladbě jednotlivých druhů jako přezky nebo ostruhy, které ukazují na formální kroj obyvatel nebo uživatelů opevnění. Nejedná se až na dvě výjimky, a to ostruhu s výzdobou B 171 a nákončí opasku s rytým drakem (B 190), o exkluzivní předměty a výrazný projev centrálního opevněného sídla. Lze konstatovat jeho výrazně vojenské užití a detašování posádky.

\section{Prameny}

CDB II: Codex diplomaticus et epistolaris regni Bohemiae V/I (Friedrich, G., ed.). Pragae 1912.

CDB IV/1: Codex diplomaticus et epistolaris regni Bohemiae IV/2 (Šebánek, J.-Dušková, S., edd.). Pragae 1962.

CDB V/1: Codex diplomaticus et epistolaris regni Bohemiae V/1 (Šebánek, J.-Dušková, S., edd.). Pragae 1974.

CDB V/2: Codex diplomaticus et epistolaris regni Bohemiae V/2 (Šebánek, J.-Dušková, S., edd.). Pragae 1981.

CIM IV/1: Privilegia nekrálovských měst českých. Privilegia non regalium civitatum provincialium regni Bohemiae IV/1 (Čelakovský, J.-Friedrich, G.-Haas, A., edd.). Pragae 1886.

FRB II: Fontes rerum Bohemicarum II (Emler, J.-Tomek, V. V., edd.). Pragae 1874.

FRB IV: Fontes rerum Bohemicarum IV (Emler, J., ed.). Pragae 1884.

RBM II: Regesta diplomatica nec non epistolaria Bohemiae et Moraviae. Pars II 1253-1310 (Emler, J., ed.). Pragae 1882.

RBM III: Regesta diplomatica nec non epistolaria Bohemiae et Moraviae. Pars III 1311-1333 (Emler, J., ed.). Pragae 1890.

SOkA NA, Městský úřad Broumov, Sbírka fotografií a reprodukcí rytin Broumovska 1609-1937, inv. č. 1-5.

\section{Literatura}

ANTONÍN, R., 2009: Alžběta Rejčka a souboj o český trůn v letech 1306-1308. In: Chrám Svatého Ducha a královna Eliška Rejčka v Hradci Králové 1308-2008. Historická tradice města. Od chrámu ke katedrále (Štěpán, J., ed.), 17-31. Ústí nad Orlicí.

BELCREDI, L., 1988: Užití kovu ve středověké osadě. Výsledky dosavadního archeologického výzkumu zaniklé středověké osady Bystřec - Die Verwendung von Metall in mittelalterlichen Siedlungen: Ergebnisse der bisherigen Untersuchungen in der MOW Bystřec, AH 13, 459-485.

- 1989: Terminologie, tř́ídění a kód středověkých kovových předmětů - Terminologie, Klassifizierung und Kode mittelalterlicher metallischer Gegenstände, AH 14, 437-472.

- 2006: Bystřec. O založení, životě a zániku středověké vsi. Archeologický výzkum zaniklé středověké vsi na Drahanské vrchovině. Brno.

BENEŠOVÁ, J., 1991: K otázce datování polohy „Hrádek“ u Bezníku (k. ú. Borek), okr. Jičín, Zpravodaj Krajského muzea v Hradci Králové 18, 85-90.

BERANOVÁ, M., 1957: Slovanské žňové nástroje, PA XLVIII, 99-117. 
BOLINA, P.-DOLEŽEL, J., 1988: Hrady na Drahanské vrchovině do konce 13. století (počáteční stav výzkumu) - Bargen auf dem Hochland Drahanská vrchovina bis zum Ende des 13. Jahrhunderts, AH 18, $321-352$.

BURIAN, V., 1979: Rozbor nálezů hřebů z hradu Tepence u Jívového a kartouzky v Dolanech (1340-1425), Zprávy Krajského vlastivědného muzea v Olomouci 202, 21-31.

CIHLA, M.-PANÁČEK, M., 2006: Středověký most v Roudnici nad Labem, PRP 13, č. 2, 3-34.

- 2011: Úvod do problematiky středověkých technologických postupů opracování stavebního kamene, Forum urbes medii aevi VI, 4-25.

CLARK, J., 1995: The Medieval Horse and Its Equipment, c. 1150-c. 1450. Medieval Finds from Excavations in London 5. London.

ČECHURA, J.-RYANTOVÁ, M., 1992: Urbář kláštera Břevnov z roku 1406, ČNM A 116, 79-107.

- 1993: Hospodářství kláštera Břevnov na počátku 15. století. In: Milénium Břevnovského kláštera (9931993). Sborník statí o jeho významu a postavení v českých dějinách (Hlaváček, I.-Bláhová, M., edd.), 197-206. Praha.

ČÍŽEK, J., 1995: Městské opevnění Broumova v archivních pramenech, Stopami dějin Náchodska 1, 17-28.

ČÍŽEK, J.-SLAVÍK, J., 2002: Systém vojenského zajištění benediktinského majetku na Broumovsku a Policku, Dissertationes historicae 7, 71-82.

DRAGOUN, Z., 1983: Gotické dýky ve sbírkách Muzea hlavního města Prahy, Archaeologica Pragensia 4, $225-261$.

DRNOVSKÝ, P., 2013: Středověké osídlení na horním toku řeky Bystřice. Ústí nad Orlicí.

- 2015: Soubor kovových nálezů z hradu Rýzmburku (okr. Náchod) ze sbírek hradeckého muzea, AVČ 6 (2013), 376-385.

- 2018: Hmotná kultura šlechtických sídel severovýchodních Čech. Každodennost ve středověku pohledem archeologie. Červený Kostelec.

DROBNÝ, T., 1995: Vývoj středověkých ostruh od 11. do počátku 16. století. Rkp. diplomové magisterské práce, ulož. v ÚAM FF MU, Brno.

DURDÍK, T., 1972: K problematice středověkých šipek v Československu, Zpravodaj Klubu vojenské historie II, 4-6; III, 5-9.

- 1976: Nálezy z hradu Týřova I. Zprávy Československé společnosti archeologické 18. Praha.

- 1989: Železné předměty z hradu Rábí, CB 1, 279-294.

- 1990: Bronzová hlavice palcátu z Plzně - Der Bronzekopf eines Morgensterns aus Plzeň, AH 15, 419-424.

- 1999: Ilustrovaná encyklopedie českých hradů. Praha.

- 2006: Monastery castle in Broumov, Europa nostra. Scientific Bulletin 60, 117-122.

DURDÍK, T.-FROLÍK, J., 1993: Hrad Vildštejn na Chrudimsku, CB 3, 47-72.

DUŠKOVÁ, S., 1988: Fälschungen böhmischer Königsurkunden im 13. Jahrhundert. In: Fälschungen im Mittelalter IV (Fuhrmann, H., ed.), 597-615. Hannover.

- 1993: Listinný poklad břevnovského kláštera z doby vlády Přemysla Otakara II. In: Milénium Břevnovského kláštera (993-1993). Sborník statí o jeho významu a postavení v českých dějinách (Hlaváček, I.Bláhová, M., edd.), 139-145. Praha.

EGAN, G.-PRITCHARD, F., 2002: Dress accessories c. 1150 - c. 1450. Medieval finds from excavations in London 3. London.

FELCMAN, O., 2017: Vztahy Broumovska a Kladska, Královéhradecko 9, 131-143.

FINGERLIN, I., 1971: Gürteln des hohen und späten Mittelalters. München - Berlin.

FROLÍK, J.-MUSIL, J., 2013: Několik poznámek k obléhání hradu Lichnice v letech 1428-1429, Chrudimský vlastivědný sborník 17, 125-214.

HANULIAK, V., 1993: Historicko-archeologický výskum Pustého hradu u Zvolena - Historisch-archäologische Forschung in Zvolen, AH 18, 161-166.

HÁSKOVÁ, J., 1991: Pražské groše (1300-1526). České moravské a slezské mince 10.-20. století. Národní muzeum - Chaurova sbírka. Praha.

HEINDEL, I., 1990: Riemen und Gürtelteile im westslawischen Siedlungsgebiet. Berlin.

HEJNA, A., 1962: Soubor nálezů z Hrádku u Bolkova v severovýchodních Čechách, PA LIII, 455-471.

- 1969: Neznámý hrádek u Radvanic, okr. Trutnov (Příspěvek ke kolonizaci území mezi Trutnovem a Broumovem), Krkonoše - Podkrkonoší 5, 67-75.

- 1974: Bradlo u Hostinného nad Labem. Příspěvek k výzkumu opevněných sídel v severovýchodních Čechách, PA LXV, 365-418.

- 1983: Kovový nálezový inventář z hradu Vizmburku, k. ú. Havlovice, o. Trutnov. Předběžná informativní zpráva - Das Fundinventar metallischer Gegenständte aus Burg Vizmburg, Katastralgemeinde Havlovice, Bez. Trutnov, AH 8, 491-501. 
HILCZERÓWNA, Z., 1956: Ostrogi poslkie X-XIII wieku. Poznań.

HLADKÝ, L., 2003: Pečeti, znak a prapor města Broumova, Stopami dějin Náchodska 9, 9-18.

- 2004: Police nad Metují. Středověké a novověké město či městečko?, Královéhradecko 1, 71-79.

HLAVÁČEK, I., 2005: Co a jak se událo či neudálo v Broumově před šesti sty lety? In: Regnum Bohemiae et Sacrum Romanum Imperium (Royt, J.-Ottová, M.-Mudra, M., edd.), 77-87. Praha.

HORÁK, J., 2002: Nálezy z hradu Vlčince u Police nad Metují, ZMHK 28, 220-226.

HRUBÝ, P. a kol., 2006: Hrubý, P.-Jaroš, Z.-Kočár, P.-Malý, K.-Mihályiová, J.-Militký, J.-Zimola, D., Středověká hornická aglomerace na Starých Horách u Jihlavy, PA XCII, 171-264.

HRUBÝ, P. a kol., 2012: Středověký úpravnický a hornický areál Cvilínek u Černova na Pelhřimovsku, PA CIII, 339-418.

HUML, V., 1967: Zaniklá tvrz Semonice. Fontes Musei Reginaehradensis - Supplementum II. Hradec Králové.

CHMIELOWIEC, S.-KAŠPAR, V.-ZDABIEWICZ, R., 2013: Sedláci a vojáci: Nálezy militárií a železných nožů ze záchranného archeologického výzkumu dvou středověkých a novověkých hospodářských dvorů v Praze-Vokovicích, ASČ 17, 275-314.

CHOTĚBOR, P., 1993: Opracování kamene v různých stavebních hutích působících na Pražském hradě Steinbearbeitung in verschiedenen Bauhütten auf der Prager Burg, AH 18, 1993, 347-357.

JANSA, P., 2004: Trutnovská kolonizační provizoria, CB 9, 63-68.

JUREK, T., 1996: Obce rycerstwo na Śląsku do połowy XIV wieku. Poznań.

KAŹMIERCZYK, J., 1978: Podkowy na Śląsku w X-XIV wieku. Wrocław - Warszawa - Kraków - Gdańsk.

KIRPIČNIKOV, A. N., 1966: Drevnerusskoje oružije 2. Kopija, sulicy, bojevyje topory, bulavy, kisteni IX.-XIII. vv., Archeologija SSSR, E 1-36. Moskva - Leningrad.

- 1973: Snarjaženie vsadnika i verchovogo konja na Rusi IX.-XIII. vv. Archeologija SSSR. Svod arheologičeskich istočnikov. Leningrad.

KLÁPŠTĚ, J., 1998: Die Anfänge der jüngeren mittelalterlichen Keramik in Böhmen als kulturhistorisches Problem, AR L, 138-158.

- 2002: Svědectví artefaktů. In: Archeologie středověkého domu v Mostě čp. 226. Mediaevalia Archaeologica 4 (Klápště, J., ed.), 10-34. Praha - Most.

KLÍMA, B., 1975: Rozbor hřebů z velkomoravského hradiště v Mikulčicích, AR XXVII, 140-150.

KOLÁČNÝ, J.-STEINOVÁ, Š.-WAAGE, V., 2017: Urbarium neoscriptum cum explicatione brevi. Čili nově sepsaný řád všech trvalých povinností a rent, které plní a odvádějí dědiční poddaní slavného kláštera Broumova ve městě a okolí. Broumov.

KOŁODZIEJSKI, S., 1985: Les éperons à molette du territoire de la Petit Pologne au Moyen Âge. In: Memoires archéologiques (Kokowski, A., ed.), 161-179. Lublin.

KOÓŠOVÁ, P., 2004: Ku klasifikácii vrcholnostredovekých ostrôh z územia Slovenska (12.-15. storočie) Zur Klassifikation der hochnmittelalterlichen Sporen auf dem Gebiet der Slowakei (12.-15. Jahrhundert), AH 29, 523-547.

KOSCELNÍK, P.-KYPTA, J.-SAVKOVÁ, J., 2013: Dobývání hradu Siónu roku 1437. Povrchový průzkum palebných postavení obléhatelů, AR LXV, 574-598.

KOUŘIL, P.-PLAČEK, M., 1985: Hrad Luginsland a jeho úloha v kolonizaci Krnovska, ČSM 34, 114-150.

KOUŘIL, P.-PRIX, D.-WIHODA, M., 2000: Hrady českého Slezska. Brno - Opava.

KOVÁCS, L., 1971: A magyar nemzeti múzeum fegyvertárának XI-XIV. Szádi csillag alakú buzogányai, Folia archeologica 22, 165-181.

KOVÁř, D., 2018: Středověké opevněné sídlo u Senožat (okr. Pelhřimov), ČSPS 126, č. 2, 86-97.

KOVÁř, M., 2010: Raně gotická architektura benediktinského kláštera v Břevnově. Praha.

KRABATH, S., 2001: Die hoch- und spätmittelalterlichen Buntmetallfunde nördlich der Alpen. Eine archäologisch-kunsthistorische Untersuchung zu ihrer Herstellungstechnik, funktionalen und zeitlichen Bestimmung. Rahden.

KRAJÍC, R., 2003: Sezimovo Ústí. Archeologie středověkého poddanského města 3. Kovárna v Sezimově Ústí a analýza výrobki̊ ze železa I, II. Praha - Sezimovo Ústí - Tábor.

KRÁSA, J., 1990: České iluminované rukopisy 13.-16. století. Praha.

KRÁSL, F.-JAŽEK, J., 1898: Sv. Vojtěch, druhý biskup pražský, jeho klášter a úcta u lidu. Praha.

LEWANDOWSKI, M., 1986: Puginały średniowieczne z ziem polskich, Acta Archaeologica Łodziensia 31, 101-119.

LIWOCH, R., 2006: Buławy z zachodniej Ukrainy, Acta Militaria Medieaevalia 2, 67-78.

LOCHMANN, Z., 1989: Archeologické nálezy ze zaniklé tvrze v Batňovicích, okres Trutnov (k 100. výročí nálezu), Krkonoše - Podkrkonoší 8, 103-119. 
MACHÁŇOVÁ, L., 2013: Módní doplňky. In: Vízmburk. Př́íběh ztraceného hradu (Koštál, J., ed.), 140150. Havlovice.

MAJER, D., 2011: Král, který létal. Moravsko-slezské pomezí v kontextu stř̌edoevropského prostoru doby Jana Lucemburského. Opava.

MAREK, L., 2008: Broń biała na Śląsku. XIV-XVI wiek. Wrattislavia Antiqua 10. Wrocław.

MAZÁČKOVÁ, J., 2012: Rokštejn: příklad zmapování vojenské kampaně proti hradu. In: Arma diaboli. O kuši a střelcích (Brych, V., ed.), 51-54. Praha.

- 2013: Militária z hradu Rokštejna v širším středoevropském kontextu. Rkp. disertační práce, ulož. v ÚAM FF MU, Brno.

- 2013a: Rokštejn Castle (Czech Republic): archaeological evidence of military activities. In: Lech, M., Weapons Bring Peace? Warfare In Medieval And Early Modern Europe, 255-289. Wrocław.

- 2013b: Militaria. In: Vízmburk. Příběh ztraceného hradu (Koštál, J., ed.), 164-170. Havlovice.

- 2017: Nástin procesu zanikání sídel ve středověku na panství Brtnice v územním rozsahu k roku 1538 Skizzierung des Wüstungsprozesses von Ansiedlungen im Mittelalter im Einzugsgebiet der Grundherrschaft Brtnice (Pirnitz) zum Jahr 1538, AH 42, 745-771.

MAZÁČOVÁ, P., 2012: Opasek jako symbol a součást středověkého oděvu. Př́íspěvek k hmotné kultuře českého středověku. Olomouc.

MĚCHUROVÁ, Z., 1995: Železné předměty ze zaniklé středověké osady Konůvky (okr. Vyškov), ČMMZ 80, 141-197.

- 1997: Konůvky - zaniklá středověká ves ve Ždánickém lese. Studie archeologického ústavu Akademie věd v Brně 17/1. Brno.

MICHALAK, A., 2018: Mystery hidden behind the Beasts' heads. Remarks on the chronology of peculiar type of medieval dagger, Acta Militaria Mediaevalia 14, 153-173.

MOTYKOVÁ, K., 2004: Nákončí opasku ze Semic na Nymbursku a znázornění draka ve středověku, Vlastivědný zpravodaj Polabí 37, 4-25.

MUSIL, F., 1995: Hrady, tvrze a zámky okresu Ústí nad Orlicí. Ústí nad Orlicí.

- 2003: K formování sociální a správní stránky manského systému v Kladsku. In: Korunní země v dějinách českého státu I. Integrační a partikulární rysy českého státu v pozdním středověku (Bobková, L., ed.), 266-274. Praha.

- 2009: Vrcholná kolonizace a východní Čechy. In: Dějiny východních Čech (Felcman, O., ed.), 301-382. Praha.

- 2012: Z dějin broumovského děkanátu, Krkonoše - Podkrkonoší 20, 317-331.

- 2016: Kolonizace Policka a Broumovska a břevnovská klášterní falza, HG 42, 137-168.

MUSIL, J., 2017: Olověná bulava z Podlažic: př́íspěvek k poznání zajímavé úderné zbraně, Chrudimské vlastivědné listy 26 , č. 4, 5-9.

NEKUDA, R., 1990: Nálezy kovových mincovních schránek na Moravě, VVM 42, 222-223.

NEKUDA, V., 1985: Mstěnice 1. Zaniklá středověká ves u Hrotovic: Hrádek - tvrz - dvůr - předsunutá opevnění. Brno.

- 2003: Středověký hrádek v katastru Vratěnína (Výsledky výzkumu r. 2003), PV 44, 123-132.

NOVÁK, M., 2004: Archeologické prameny k nejstarším dějinám Polického újezdu, ZMHK 30, $159-175$.

NOVOTNÝ, V., 1928: České dějiny I.3. Čechy královské za Přemysla I. a Václava I. (1197-1253). Praha.

PEKOVIĆ, M., 2006: Archeološka sbirka Vojnoj mzeja v Beogrady - Archaeological collection of the Military museum in Belgrade. Belgrade.

PLAČEK, M., 1996: Hrady a zámky na Moravě. Praha.

PREISS, P.-VILÍMKOVÁ, M., 1989: Ve znamení břevna a růží. Historický, kulturní a umělecký odkaz benediktinského opatství v Břevnově. Praha.

PROCHÁZKA, R., 1990: Kovové předměty z výbavy středověkého měšt’ana z výzkumu v Brně - Pekařské ulici - Metallgegenstände der Ausstattung der mittelalterlichen Bürgers aus der Ausgrabung in Brno Pekařská ulice, AH 15, 99-109.

RAGAČ, R., 2001: Heraldické motívy na kovovej miniatúre z lokality Zvolen-Pustý hrad - Heraldische Motive auf der metallenen Miniatur aus der Lokalität Zvolen-Pustý hrad, AH 26, 441-445.

RICHTER, M., 1982: Hradišt'ko u Davle. Městečko ostrovského kláštera. Praha.

RICHTER, M.-VOKOLEK, V., 1995: Hradec Králové. Slovanské hradiště a počátky středověkého města. Hradec Králové.

RUTTKAY, A., 1976: Waffen und Reiterrüstung des 9. bis zur ersten Hälfte des 14. Jahrhunderts in der Slowakei (II), S1Arch XXIV, 245-395.

- 1989: Prvky gotickej módy v odeve a ozdobách dedinského obyvatel'stva na území Slovenska (horizont hrobov zo 14.-15. stor. v Ducovom, obec Moravany nad Váhom) - Elemente der gotischen Mode in 
Kleidung und Schmuck bei der ländlichen Bevölkerung auf dem Gebiet der Slowakei (Grabhorizont aus dem 14.-15. Jh. in Ducové, Gemeinde Moravany nad Váhom), AH 14, 355-378.

SIGL, J., 1980: Výzkum středověkého hrádku u Úhlejova (o. Jičín), Zpravodaj Krajského muzea východních Čech 7, 20-25.

- 1991: Zjišt’ovací výzkum středověkého hrádku u Božanova, okr. Náchod v roce 1991, ZMHK 18, 94-102.

- 1995: Božanov, okr. Náchod, Výzkumy v Čechách 1990/2, 30.

SIGL, J.-WOLF, V., 1983: Archeologický výzkum v Trutnově 1980-1981, Krkonoše - Podkrkonoší 7, 267-301.

- 1983a: Bezejmenný hrádek u Vlčic, okr. Trutnov, AR XXXV, 639-645.

- 1989: Zjišt’ovací archeologický výzkum hrádku v poloze Hradiště u Horních Štěpanic a jeho přínos k poznání kolonizačního procesu na Jilemnicku, Z Českého ráje a Podkrkonoší 2, 7-14.

SLAVÍK, J., 2014: Nové poznatky o stavebním vývoji kláštera v Broumově před barokní přestavbou. In: Gotické a raně renesanční umění ve východních Čechách 1200-1550 (Hlobil, I.-Dospěl, M., edd.), 18-32. Hradec Králové.

SLIVKA, M., 1981: Stredoveké hutníctvo a kováčstvo na východnom Slovensku III, Historia Carpatica 12 , 211-276.

SMOLÍK, J., 1971: Pražské groše a jejich díly (1300-1547), Praha 1894 - doplnili K. Castelin a I. Pánek. Praha.

STOLL, H., 1993: Der Bühl von Jenaläbnitz - ein mittelalterlicher Burghügel in Ostthüringen. Weimarer Monographien zur Ur und Früh Geschichte. Band 29. Stuttgart.

ŚWIĘTOSŁAWSKI, W., 1990: Strzemiona średniowieczne z ziem Polski. Łódź.

- 1996: Uzbrojenie koczowników Wielkiego stepu w czasach ekspansji Mongołów (XII-XIV w.). Łódź.

ŠAUROVÁ, D., 1978: Hřeby z výzkumu zaniklých Konůvek, AR XXX, 560-566.

ŠEBÁNEK, J.-DUŠKOVÁ, S., 1963: Listina v českém státě doby Václava I. (u nižších feudálů a měst). Praha.

S̆IMÁK, J. V., 1936: Počátky Broumova a Broumovska, ČČH 42, 575-582.

- 1938: České dějiny I.5. Středověká kolonisace v zemích českých. Praha.

ŠMELHAUS, V., 1976: Broumovský urbář 1676/7. Text a textové př́ilohy. Praha.

ŠRÁMEK, J., 2009: „Aby události neunikly paměti.“ Středověká listinná falza a kláštery, Acta historica Universitatis Silesianae Opaviensis 2, 13-37.

- 2010: „Ctihodný otec a pán Bavor, z Božího milosrdenství opat břevnovský, téhož místa téměř druhý zakladatel.“K vytváření obrazu osobnosti v historiografii, Církevní dějiny 3, 16-33.

- 2013: Břevnovská listinná falza a počátky osidlování Broumovska pohledem současného dějepisectví. In: Dějepis kláštera břevnovského a broumovského (Růžička, J., ed.), XXXIII-XLV. Praha.

- 2015: Formování klášterní domény ve 13. a 14. století na př́íkladu benediktinských proboštství v Polici nad Metují a Broumově, Historica Olomucensia 48, 13-42.

- 2017: Benediktinské expozitury ve východních Čechách doby předhusitské. Příspěvek k otázce geneze a významu klášterních dependencií, Východočeský sborník historický 32, 141-171.

- 2017a: Opat Bavor z Nečtin a vývoj břevnovského klášterství v době posledních Přemyslovců se zřetelem k severovýchodním Čechám, Východočeský sborník historický 31, 79-103.

ŠŮLA, J., 1996: Pohyb česko-kladské hranice v období feudalismu, Kladský sborník 1, 27-30.

TICHÝ, R.-TŮMA, J.-WOLF, V., 1999: Předběžná zpráva o archeologickém výzkumu hradu u Stárkova $\mathrm{v}$ roce 1999 , ZMHK 25, 110-121.

TOMEK, V. V., 1857: Paměti újezdu Polického čili nynějších panství Broumovského a Polického z časů před válkou Husitskou, Památky archaeologické a místopisné II, 200-213, 241-249.

- 1881: Příběhy kláštera a města Police nad Medhují. Praha.

UNGER, J., 1994: Koválov: Šlechtické sídlo z 13. století na jižní Moravě. Brno.

- 1999: Život na lelekovickém hradě ve 14. století. Antropologická sociokulturní studie. Brno.

URBÁNEK, R., 1948: Legenda tzv. Kristiána ve vývoji předhusitských legend václavských a ludmilských a její autoři II.2. Praha.

VELÍMSKÝ, T., 1979: Smilovo hradisko, Mikulovská sympozia 78, 105-110.

VÍCH, D., 2010: Neznámá vrcholně středověká fortifikace na k. ú. Lanšperk, CB 12, 331-343.

- 2013: Archeologické nálezy z jedné privátní sbírky, ASČ 17, 315-331.

- 2014: Kovové nálezy z hradu v Brandýse nad Orlicí, CB 14, 142-155.

- 2015: Př́íspěvek k poznání tvrziště v Českých Libchavách na Ústeckoorlicku - Ein Beitrag zu den Erkenntnissen über die Festungsstätte in České Libchavy im Bezirk Ústí nad Orlicí, AH 40, 163-177.

- 2016: Hrad v Hrádníkách u Zářecké Lhoty na Choceňsku - Eine Burg in Hrádníky bei Zářecká Lhota in der region Choceň, AH 41, 133-166. 
- 2016a: Archeologické nálezy z předpolí drobné vrcholně středověké fortifikace v k. ú. Lanšperk, CB 13 , 321-333.

VÍCH, D.-ŽÁKOVSKÝ, P., 2016: Vojenské vybavení bojové družiny před husitskou revolucí. Soubor militarií z hradu Orlík u Brandýsa nad Orlicí ve východních Čechách, PA CVII, 279-351.

VLČEK, P.-SOMMER, P.-FOLTÝN, D., 1998: Encyklopedie českých klášterů. Praha.

VOGT, H. J., 1987: Die Wiprechtsburg Groitszsch, eine mittelalterliche Befestigung in Westsachsen. VEB Deutscher Verlag der Wissenschaften. Berlin.

WACHOWSKI, K., 1994: Profilierte Schnallen in Mitteleuropa, Zeitschrift für Archäologie des Mittelalters $22,181-186$.

WACHOWSKI, K.-WRÓBEL, M., 2002: Śląskie pojemniki na brakteaty na tle porównawczym, Archeologia Polski 47, č. 1-2, 345-354.

WOLF, O., 2005: Počátky středověkého osídlení na českoslezském pomezí východních Krkonoš. Rkp. disertační práce, ulož. v ÚAM FF MU, Brno.

WOLF, V., 1977: K problematice středověkých horských hrádků ve východním podhůří Krkonoš - Mittelalterliche Bergfesten im östlichen Vorland des Riesengebirges, AH 2, 105-116.

- 1983: Hrad Rechenburk u Trutnova. Příspěvek k poznání zárodečné fáze stř̌edověkého hradu, Krkonoše Podkrkonoší 7, 251-266.

- 1998: K problematice tzv. kolonizačních provizorií (Úvaha nad funkcí a fortifikací), CB 6, $107-116$.

WOLF, V.-SIGL, J.-JIRÁSEK, L., 1987: Neznámá opevněná lokalita v Hajnici, okr. Trutnov, Zpravodaj Krajského muzea východních Čech v Hradci Králové 14, 76-87.

ZŮBEK, A., 2002: Středověké přezky v brněnských nálezech, SPFFBU M 7, 123-153.

ŽÁKOVSKÝ, P., 2011: Středověká a raně novověká militaria ze sbírek Lovecko-lesnického muzea v Úsově na Moravě, Acta Militaria Mediaevalia 7, 105-159.

- 2011a: Středověké a raně novověké chladné zbraně ze sbírek Městského muzea v Moravském Krumlově. In: Hrad jako technický problém. Technologie a formy výstavby středověkých opevněných sídel. Archaeologia mediaevalis Moravica et Silesiana 2/2010 (Měřínský, Z., ed.), 127-188. Brno.

- 2014: Tesáky a problematika jednosečných zbraní středověku ar raného novověku. Rkp. disertační práce, ulož. v ÚAM FF MU, Brno.

ŽÁKOVSKÝ, P.-HOŠEK, J., 2015: Kovové artefakty. In: Veselí nad Moravou. Středověký hrad v říční nivě (Plaček, M.-Dejmal, M., edd.), 220-251. Brno.

ŽEMLIČKA, J., 1993: K hodnověrnosti listiny Jana XV. pro klášter v Břevnově (31. V. 993). In: Milénium Břevnovského kláštera (993-1993). Sborník statí o jeho významu a postavení v českých dějinách (Hlaváček, I.-Bláhová, M., edd.), 25-39. Praha.

- 1998: Století posledních Přemyslovců. Praha.

- 2002: Počátky Čech královských 1198-1253. Proměna státu a společnosti. Praha.

- 2014: Království v pohybu. Kolonizace, města a stř́ibro v závěru přemyslovské epochy. Praha.

\section{Zusammenfassung}

\section{Die Burg bei Božanov im Braunauer Ländchen und ihre mögliche Aufgabe bei der Stabili- sierung des Klosterdominiums Braunau (Broumov)}

Die befestigte Fundstelle, deren ursprünglicher Name in den schriftlichen Quellen nicht überliefert ist, befindet sich in der Nähe des Dorfes Božanov in einem Ausläufer des Braunauer Ländchens (Bezirk Náchod). Entsprechend dem Namen dieses Dorfes wird die Befestigungsanlage in der gegenwärtigen Literatur dann als Burg bei Božanov bezeichnet. Die Burg wurde auf einem schmalen Bergrücken errichtet, dessen Abschüssigkeit natürlich und absichtlich als Verteidigungselement genutzt wird. Die Burg war außer an der Nordseite von einem Graben und einem Wall umgeben. Die Fundstelle besteht aus einem erhöhten zentralen Plateau mit Außenbefestigung. Das zentrale Plateau wird durch einen Graben und einen Erdwall abgegrenzt. An der Westseite fehlt der Erdwall, da hinter dem Graben ein rezenter Waldweg verläuft, wegen dem der Erdwall bei der Anlage des Weges zerstört werden konnte. Die längere Achse ist eine ovale, in Richtung Bergrücken orientierte Fläche mit den Maßen $15 \times 43 \mathrm{~m}$, die 3,5 m über dem östlichen $18 \times 30 \mathrm{~m}$ großen Plateau liegt. Die gesamte Geländesituation erlaubte es, das breite Flussgebiet des Wasserlaufs Steine (Stěnava) im Braunauer Becken in dem im Nordosten vom Heidelgebirge 
(Javoří hory) abgegrenzten Streifen zu kontrollieren. Eine Sichtweite von bis zu $10 \mathrm{~km}$ umfasst auch Broumov selbst, mit dem es in direktem visuellen Kontakt steht.

Die bisher einzige Geländefreilegung, bzw. Feststellungssondierungsgrabung wurde im Jahr 1991 von J. Sigl durchgeführt (Sigl 1995, 30, Lage 124). Im Burgareal wurden insgesamt drei Sondierschnitte gelegt. Im Laufe des Jahres 1993 hat J. Hlaváček über 270 Metallfunde auf der Burg entdeckt, die schließlich dem Museum in Hradec Králové übergeben wurden. Seit den neunziger Jahren des vergangenen Jahrhunderts wurde die Fundstelle dann bis zur Gegenwart zu einem häufigen Objekt illegaler Detektorsuche. Einen Teil der auf diese Weise erworbenen Gegenstände gelang es Dank einer Verständigung mit den Findern, der Museumssammlung in Hradec Králové einzuverleiben.

Der bearbeitete Fundkomplex setzt sich zusammen aus Posten, die teilweise als chronologisch unsensibel (z.B. Bestandteil von Baubeschlägen, Bestandteile der Betriebsausstattung), bzw. als Gegenstände bezeichnet werden können, die allgemein in den gröberen Zeitrahmen des 13.-16. Jahrhunderts datierbar sind (z.B. Werkzeuge des Handwerks und landwirtschaftliche Geräte, Kleidungsbestandteile). Trotzdem erlauben uns einige Artefakte eine genauere chronologische Einordnung. Dabei handelt es sich in erster Linie um zwei numismatische Funde. Für die sog. Brakteaten-Hülse (B 201) kann eine Analogie von der Burgruine Obřany (Brno-Obřany) und unter den vor 1288 datierten Meißener Brakteaten gefunden werden. Der zweite Fund - ein Prager Groschen von Wenzel II. (B 202) - kann dann den Anfangsjahren des 14. Jahrhunderts zugeordnet werden. $\mathrm{Zu}$ den chronologisch sensibleren Gegenständen zählen auch Sporen. Die vertretenen Typen ermöglichen eine Einordnung in den Zeitraum ab der zweiten Hälfte des 13. Jahrhunderts bis zum Beginn des 14. Jahrhunderts. Eine ähnliche zeitliche Bestimmung ermöglicht auch eine Gürtelzunge mit der Darstellung eines Drachens (B 190). Die weitere (chronologisch zwar weniger sensible) Kategorie der Metallfunde (Sicheln, Hufeisen, Zaumzeuge, Striegel, Steigbügel, Streitkolbenkopf, Dolch) steht ebenfalls in keinem Widerspruch zur Einordnung der Fundstätte in den zeitlichen Rahmen ab der zweiten Hälfte des 13. Jahrhunderts bis in den Verlauf des 14. Jahrhunderts. Für die in drei Gruppen unterteilten Keramikfunde können Analogien in Fundkomplexen gefunden werden, die von solchen Fundstellen aus der nordöstlichen Region stammen, deren Betrieb allgemein in den Verlauf der zweiten Hälfte des 13. Jahrhunderts bis ins ganze darauffolgende Jahrhundert datiert wird. Den chronologisch sensibleren Keramikfunden können drei Fragmente von Bügelkannen zugeordnet werden. Insgesamt lässt sich der Fundkomplex datierungsmäßig in den Verlauf der zweiten Hälfte des 13. Jahrhunderts bis zum Beginn des 14. Jahrhunderts einordnen. Diesem Zeitraum widersprechen auch nicht die übrigen Posten der Sammlung.

Aufgrund einer Analyse der für das gegebene Gebiet betreffenden schriftlichen Quellen ist offensichtlich, dass in dem Zeithorizont, in den der Betrieb der untersuchten Fundstelle gelegt werden kann, die Braunauer Benediktiner die Herren des Gebietes waren (mit Ausnahme der Zeit der Verpfändung an Heinrich IV. Probus in den Jahren 1279-1290). Die Entstehung und der Betrieb von Burg Božanov muss demnach offensichtlich gerade mit dem Besitz der Benediktiner in Zusammenhang gebracht werden. Diese Hypothese kann durch eine Reihe von Tatsachen gestützt werden. Ein grundsätzlicher Faktor ist dabei die bereits oben beschriebene Lage der Fundstelle im Braunauer Ländchen. Von der Fundstelle aus war es möglich, den Eingang zum Braunauer Becken im Osten zu kontrollieren, und Dank ihrer Lage war sie von den benachbarten Herrschaften aus auch aus einer beträchtlichen Entfernung gut sichtbar. Die Burg konnte demnach einen gedachten Grenzpunkt darstellen, der den Besitz des Klosters zum angrenzenden Glatz abgrenzte.

Darauf, dass es sich eher um einen Wachpunkt handelte, deutet auch das Aussehen des Sitzes selbst und die Zusammensetzung des Fundinventars hin. Im Hinblick auf den Umfang der Fundstelle und besonders im Hinblick auf ihre Lage außerhalb der Besiedelung kann nicht mit einer Verwaltungsfunktion gerechnet werden. Auf die Präsenz eines eher militärischen Gefolges deutet besonders die Zusammensetzung der Funde hin, die mit der Stallung von Pferden und deren Ausrüstung in Verbindung gebracht werden können. 
In Nordostböhmen können mehrere vergleichbare Fundstellen gefunden werden, die durch eine Reihe analoger Faktoren miteinander verbunden sind. In erster Linie handelt es sich um die qualitativ nicht allzu gute Gründung der Befestigungsanlagen, für die eine Kombination von Gräben und leichteren Befestigungsformen verwendet wurde. Auch der Umfang dieser Sitze ist nicht groß, in der Regel handelt es sich bei ihnen lediglich um einteilige, ggf. zweiteilige Anlagen mit Kern und Vorburg. Typisch für sie ist auch die Entfernung von den damaligen Besiedelungszentren und ihre Lage am Rand der damaligen Siedlungsökumene. Ein Betrieb über einen nur kurzen Zeitraum kann sich dann bloß in einem Siedlungshorizont widerspiegeln. Im Vorland des Riesengebirges handelt es sich beispielsweise um die Sitze Bezník bei Borek (Benešová 1991), Bolkov bei Zlatá Olešnice (Hejna 1962), Hajnice-Kyje (Wolf-Sigl-Jirásek 1987), Horní Vlčice bei Trutnov (Sigl-Wolf 1983a), Hradiště bei Horní Štěpanice (Sigl-Wolf 1989), Rechenburk bei Libeč (Wolf 1977; 1983), Starý zámek bei Radvanice (Hejna 1969) und Šluspárk bei Úhlejov (Sigl 1980). Vladimír Wolf (1998, 107-116) verwendete für diese Fundstellen die Bezeichnung sogenannter Kolonisationsprovisorien und brachte sie mit der Bildung von Herrschaften und der Sicherung ihrer Grenzen in einen Zusammenhang. Nach Stabilisierung der Besitzverhältnisse seien diese Befestigungsanlagen dann aufgegeben worden. Dieser Begriff bzw. Fundstellentyp ist auch aus anderen Gebieten Böhmens und Mährens bekannt, obgleich er bislang nicht vollständig definiert wurde und in verschiedenen Regionen unterschiedliche Ausformungen erlangen kann (vgl. Bolina-Doležel 1988, 328-330; Kouřil-Plaček 1985, 125; Musil 1995, 30-31; Plaček 1996, 31; Velímský 1979). Einen Teil der oben aufgeführten Fundstellen (Bolkov bei Zlaté Olešnice, Hajnice-Kyje, Horní Vlčice bei Trutnov, Starý zámek bei Radvanice und Rechenburk bei Libeč) pflegt man mit dem Aufbau des Dominiums des Geschlechts der Schwabenitzer in der Region Trutnov in Verbindung zu bringen (Jansa 2004; Musil 2009, 332). Die befestigten Sitze Bezník bei Borek und Šluspárk bei Úhlejov hängen dann offenbar mit der Besiedelung der Gegend um Miletin in der Region Jičín zusammen (Drnovský 2013, 27-28).

Die Burg bei Božanov könnte somit mit einer ähnlichen Absicht gegründet worden sein. Die Grenze des Braunauer Ländchens, bzw. der Rand der neu entstandenen Siedlungsökumene des Braunauer Klosters, musste gegenüber dem benachbarten Glatz abgegrenzt werden. Die Errichtung einer kleinen, trotzdem jedoch dominanten befestigten Lage an der unmittelbaren Grenze des Klosterbesitzes hat aus Sicht der Benediktiner eine optimale Lösung darstellen können, mit der eventuelle Kolonisationsbestrebungen aus Glatz verhindert werden konnten. Am Sitz kann man dann mit der Präsenz einer kleinen Garnison rechnen, die den Grundbetrieb des Sitzes gewährleistete, der ansonsten von der Verbindung zu den Klosterdörfern am Fuße der Braunauer Wände (Falkengebirge) abhängig wäre.

Die Aufgabe des Sitzes kann mit der Rebellion der Braunauer Vögte im Jahr 1300 und mit den anschließenden Ereignissen einschließlich des Baus der Burg in Braunau (Broumov) zusammenhängen. Über den Verlauf dieser Ereignisse sind wir aus den Dokumenten des Abtes Bavor von Nečtiny informiert, der die Schäden am Klosterbesitz erwähnt. Ein plötzliches Verschwinden des befestigten Sitzes Božanov wird unter anderem durch die umfangreiche Sammlung an Metallgegenständen angedeutet, die an der Fundstelle zurückgelassen wurden. Zu Beginn des 14. Jahrhunderts waren offensichtlich auch die Grenzen des Braunauer Klosterbesitzes konsolidiert, und der ursprüngliche Sinn der Befestigungsanlage hatte seine Gültigkeit bereits verloren. Dass der Standort nicht wiederhergestellt wurde, muss auch im Zusammenhang mit dem Bau einer Befestigungsanlage direkt im Zentrum von Braunau gesehen werden. Die Erfahrungen des Abtes mit den Kämpfen des Jahres 1300 könnten zu der Erkenntnis beigetragen haben, dass es bereits überflüssig war, einen entfernt liegenden Verteidigungspunkt zu betreiben, der im Falle einer Bedrohung des Klosters selbst, keine wirkliche Hilfe sei. Es ergab sich hingegen die Notwendigkeit, direkt im Areal der Stadt und des Klosters eine Befestigungsanlage zu errichten. Die Entstehung (bzw. der Umbau) des Braunauer castrums zu Beginn des 14. Jahrhunderts könnte somit bedeutet haben, dass es überflüssig geworden war, die oberhalb des Dorfes Božanov liegende eingenommene und wahrscheinlich auch zerstörte Burg wieder aufzubauen. 
Mgr. Pavel Drnovský, Ph.D., Katedra archeologie Filozofické fakulty Univerzity Hradec Králové, Rokitanského 62, 50003 Hradec Králové, Česká republika,pavel.drnovsky@uhk.cz

Mgr. Jana Mazáčková, Ph.D., Ústav archeologie a muzeologie Filozofické fakulty Masarykovy univerzity, Kounicova 67a, 60200 Brno, Česká republika,jkrejsov@phil.muni.cz

Mgr. Josef Šrámek, Ph.D., Historické oddělení Muzea východních Čech v Hradci Králové, Opletalova 334, 50003 Hradec Králové, Česká republika,j.sramek@muzeumhk.cz 
